\title{
Developing a Marginalized and Segregated Community: Case Study of a West Virginia Neighborhood
}

\author{
Christopher Belkon Agba \\ West Virginia University, cbagba@mix.wvu.edu
}

Follow this and additional works at: https://researchrepository.wvu.edu/etd

Part of the Social and Behavioral Sciences Commons

\section{Recommended Citation}

Agba, Christopher Belkon, "Developing a Marginalized and Segregated Community: Case Study of a West Virginia Neighborhood" (2020). Graduate Theses, Dissertations, and Problem Reports. 7604.

https://researchrepository.wvu.edu/etd/7604

This Dissertation is protected by copyright and/or related rights. It has been brought to you by the The Research Repository @ WVU with permission from the rights-holder(s). You are free to use this Dissertation in any way that is permitted by the copyright and related rights legislation that applies to your use. For other uses you must obtain permission from the rights-holder(s) directly, unless additional rights are indicated by a Creative Commons license in the record and/ or on the work itself. This Dissertation has been accepted for inclusion in WVU Graduate Theses, Dissertations, and Problem Reports collection by an authorized administrator of The Research Repository @ WVU.

For more information, please contact researchrepository@mail.wvu.edu. 


\section{Developing a Marginalized and Segregated Community: Case Study of a West Virginia Neighborhood}

\section{Christopher B. Agba}

Dissertation Submitted

to the Davis College of Agriculture and Natural Resources at West Virginia University

in partial fulfillment of the requirements for the degree of

Doctor of Philosophy in

Human and Community Development

Peter Schaeffer, Ph.D., Chair

Melissa Sherfinski, Ph.D.

Alan Collins, Ph.D.

Deborah A. Boone, Ph.D.

Daniel Eades, M.A.

Department of Design and Community Development

Morgantown, West Virginia

2020

Keywords: Marginalization, segregation, desegregation, community, leadership

Copyright 2020 Christopher B. Agba 


\section{Abstract \\ Developing a Marginalized and Segregated Community: Case Study of a West Virginia Neighborhood}

\section{Christopher B. Agba}

A lot of work has been done in the field of community development targeting less developed communities. Many questions have also been raised about why some communities are not as responsive to change as others, despite the efforts and recommendations. This dissertation, therefore, is a critical attempt on how to develop a specific, marginalize and segregated neighborhood, using residents' historical narratives and worldviews in Westside, Fairmont, West Virginia. The author uses focus group discussions, informal communications and semistructured interviews as primary data sources. He analyzed the manuscript of W.O. Armstrong, the pioneer principal of Dunbar School, which was an All-Black school serving the neighborhood as secondary data source. The research also uses critical theory framework because of its concern with ontology, epistemology and methodology of reality (Crotty, 2012) to explore the narratives of race, segregation and desegregation in the Westside community.

The results of this research include systemic discrimination in education, employment, social, economic and infrastructural development; fractured relationships between residents, city, organizations and associations; and lack of purposeful leadership as when Dunbar School was in the community. The study, therefore, fills a gap in the development literature by contributing both a critical and specific and situated perspective into how to develop a marginalized neighborhood. 


\section{Dedication}

To God the Father, Son and Holy Ghost, who make everything beautiful in His time. To the loving memories of Dr. Akomaye Oko and his daughter Inyite Oko, who saw this coming long before anyone could. To Kushelunim, my son, and every child around the world who dares to dream and believe that luck is what happens when preparations meet opportunity (Senecca). 


\section{Acknowledgment}

Many thanks to Dr. Peter Schaeffer for his incredible and invaluable advice through this dissertation process. Your feedback provided different lenses from which to view, analyze and explain race and related issues. I am indebted to Dr. Melissa Sherfinski for her priceless advice right from the beginning of this dissertation, thank you! Dr. Collins' role in this process started during my first visit to West Virginia University back in 2015. I am glad that he is on my committee and has played a remarkable part through every stage of the dissertation. Dr. Debby Boone and Daniel Eades, you were never tired of me knocking at your office doors, thank you for your support and encouragement all along. Special thanks also, to Drs Margaret Stout and Shanequa Smith for roles in all of these. A huge thank you to the greater West Virginia University Community for creating a unique learning environment for all. Special thank you to WVU Graduate Education and Life, and the Division for Diversity, Equity and Inclusion for providing me with graduate funding.

To my clan, Talisa, my wife, Umali, Undiga, Dr. Emilia Oko, Victoria Ukeh-Agba and all, too many to mention, I am grateful. 


\section{Table of Contents}

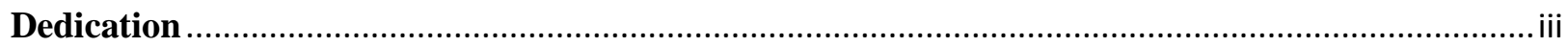

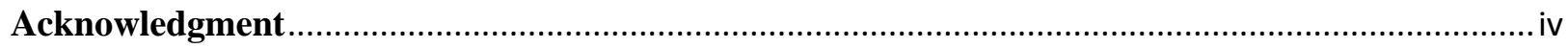

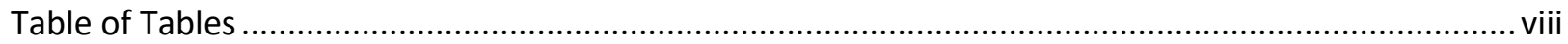

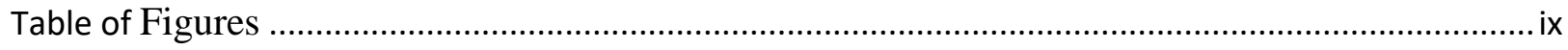

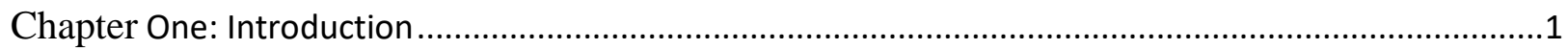

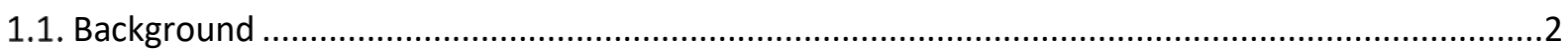

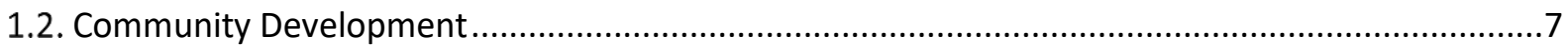

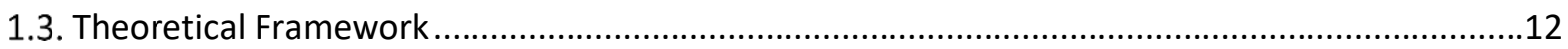

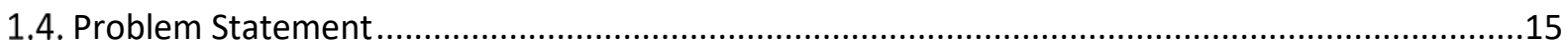

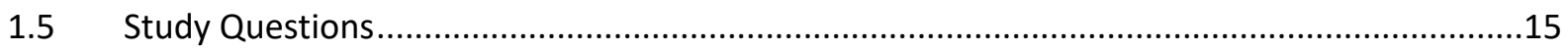

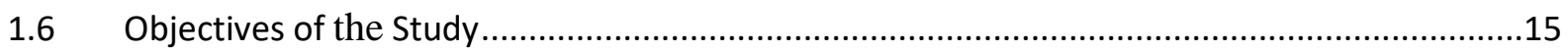

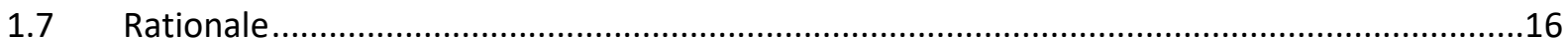

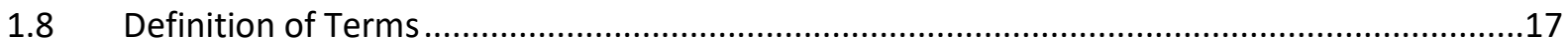

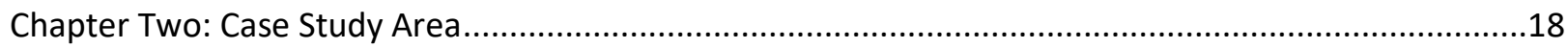

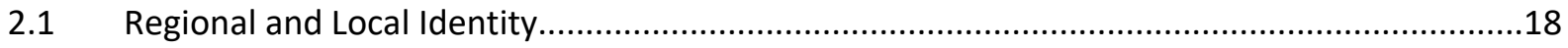

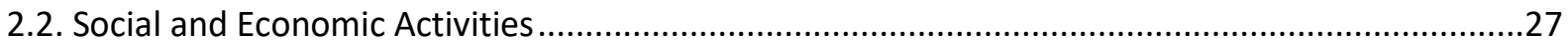

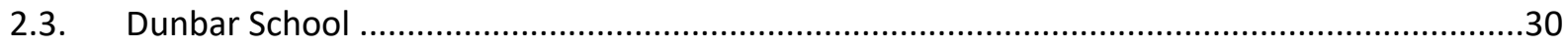

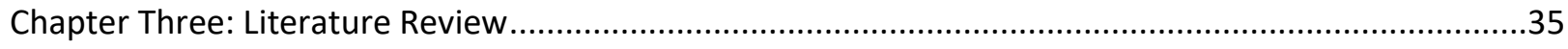

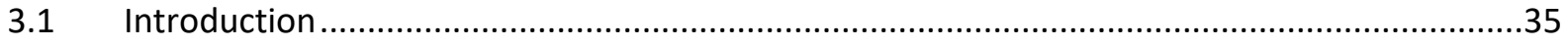

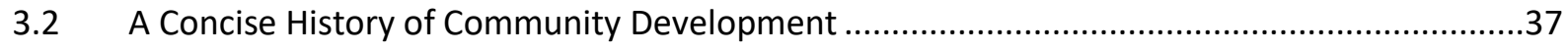

3.3 Approaches in Community Development …......................................................................

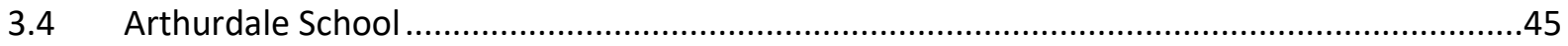

3.5 Education and African American Communities ..................................................................

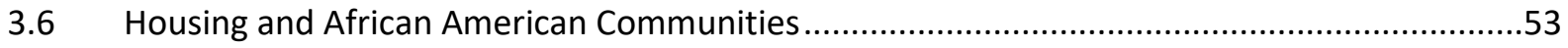




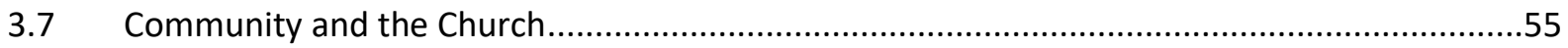

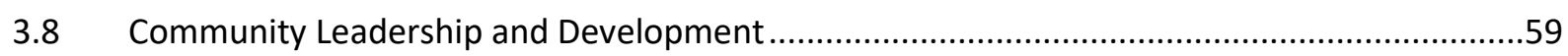

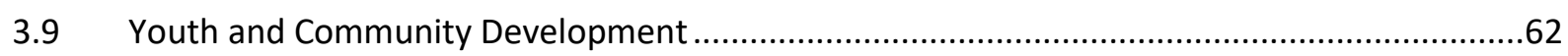

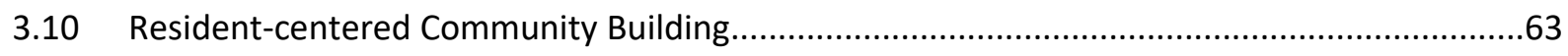

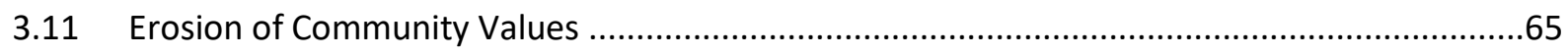

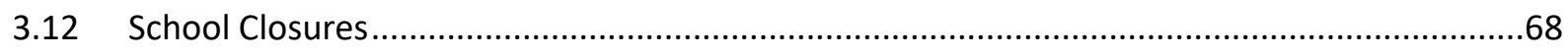

3.13 Power Relations and Community Development ….........................................................

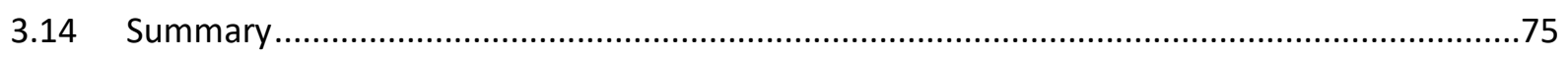

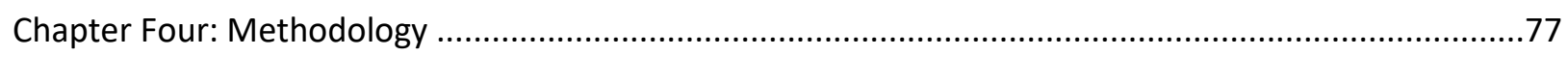

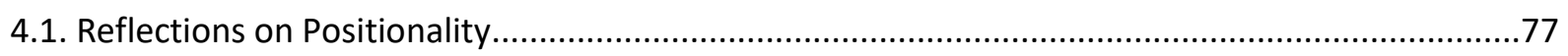

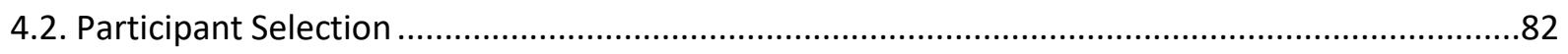

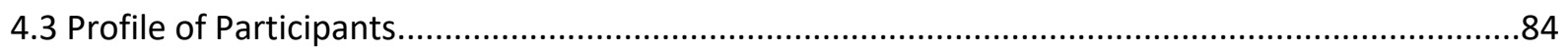

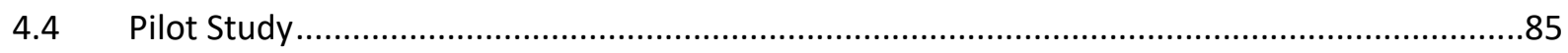

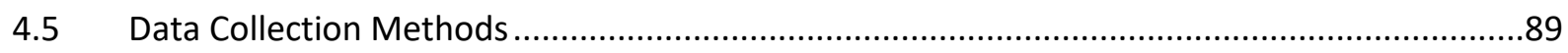

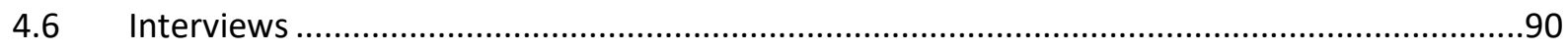

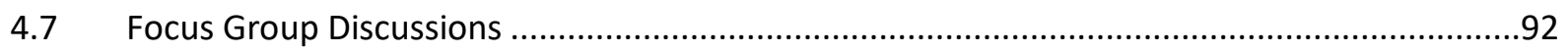

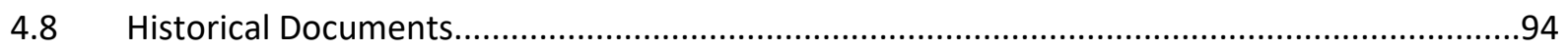

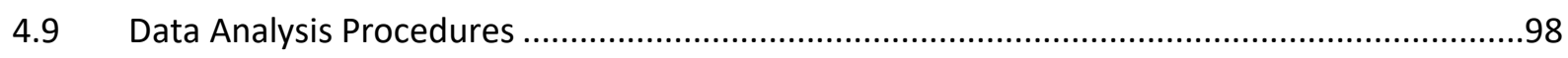

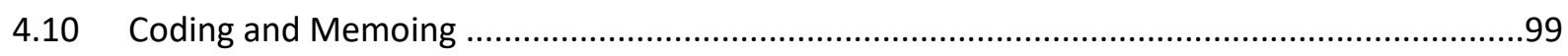

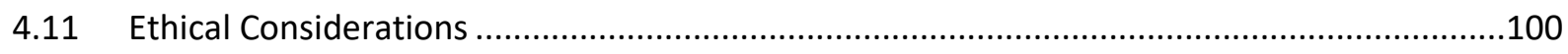

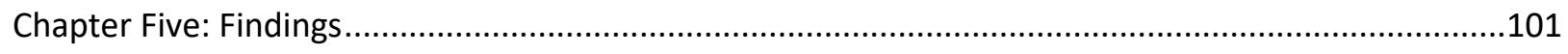

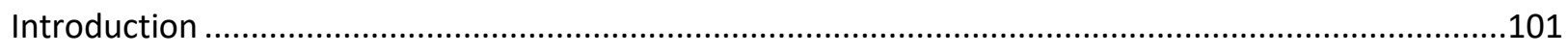

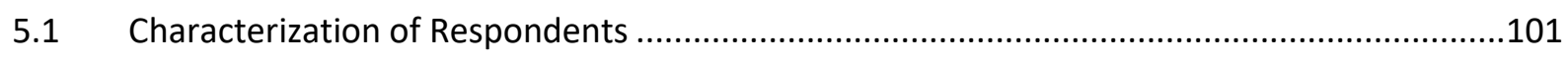

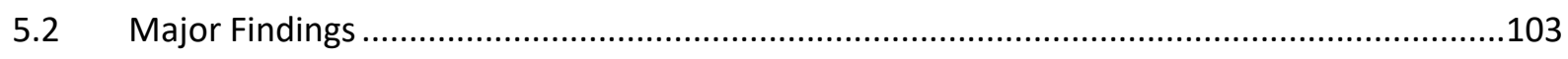

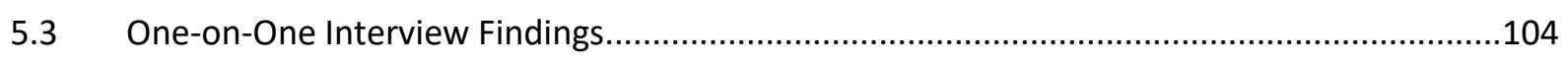

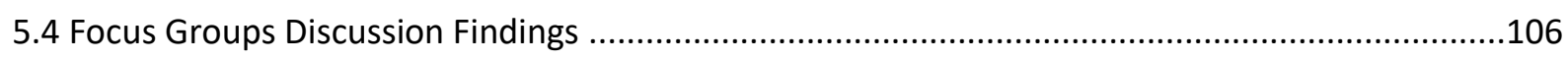


6.1 Research Question 1: How have race, segregation, and desegregation influenced relationships and trust among residents?

6.2 How have past experiences shaped leaders in the neighborhood?....

6.3 How have residents' perceptions of discrimination shaped the neighborhood's relationships with city government?

6.4 What was the impact on the Westside community when the role of Dunbar School changed after desegregation?

6.5 And what have been the impacts of past community revitalization initiatives in the neighborhood?

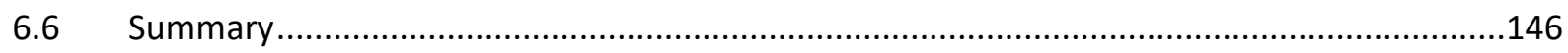

Chapter Seven: Implications, Recommendations and Conclusions ..................................................149

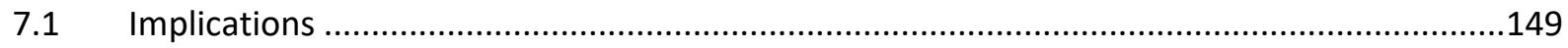

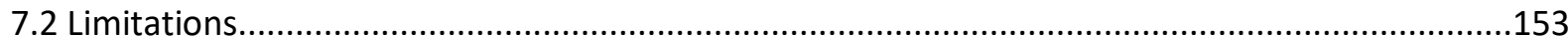

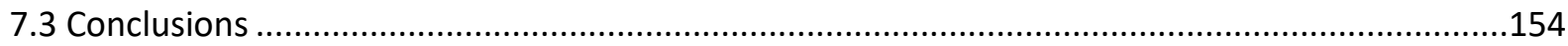

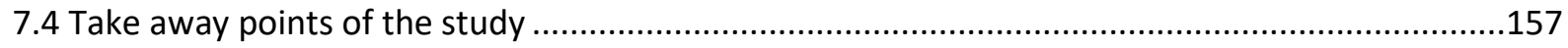

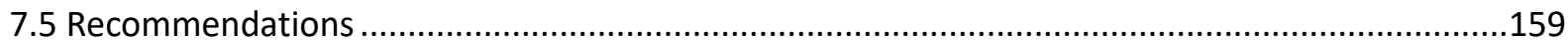

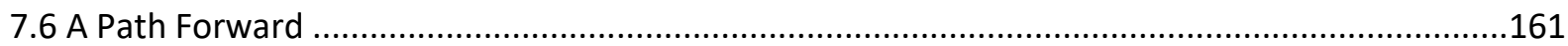

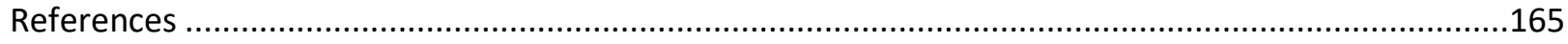

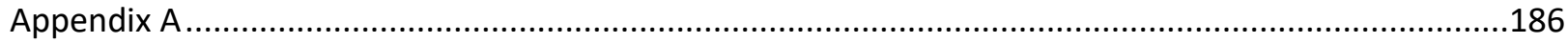

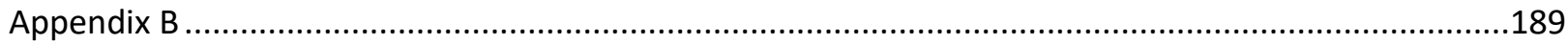




\section{Table of Tables}

Table 1: Marion County, West Virginia Population $2019 \ldots \ldots \ldots \ldots \ldots \ldots \ldots \ldots \ldots \ldots \ldots \ldots$

Table 2: Characteristics of participants............................................. 102

Table 3 a Interview participants findings......................................... 104

Table 3 b, Interview Participants findings.......................................... 105

Table 3 c \& d: Interview participants findings.................................... 106

Table 4: Focus Group Discussions findings..................................... 108 


\section{Table of Figures}

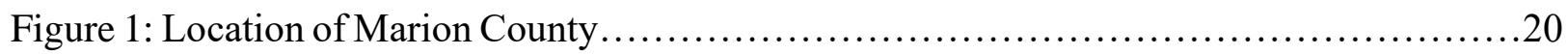

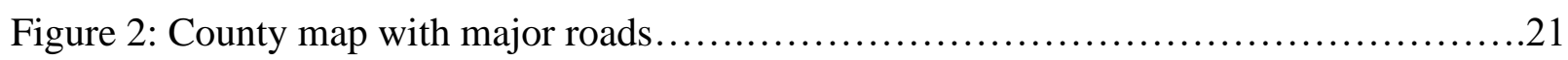

Figure 3: Percentage racial population distribution in Fairmont............................. 22

Figure 4: African American Population Percentage, 2013 and 2018 _.........................23

Figures 5 \& 6: Neighborhood maps and landmarks with aerial photo in the background.........24

Figure 7: Population change in Fairmont from 1970 through 2016...........................27

Figure 8: Frontal View of Dunbar School as it is today ........................................

Figure 9: Dunbar School basketball team that went undefeated.............................34

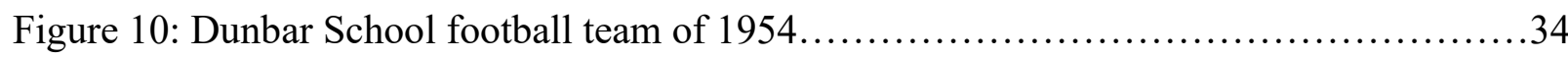

Figure 11: Churches with High Level of Conflict........................................57

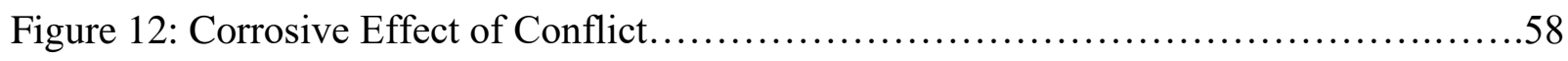

Figure 13: A Sharp Erosion of Spiritual Vitality..........................................58

Figure 14: Profile of Interview Participants.............................................. 84

Figure 15: Profile of Focus Group Discussion Participants................................. 85

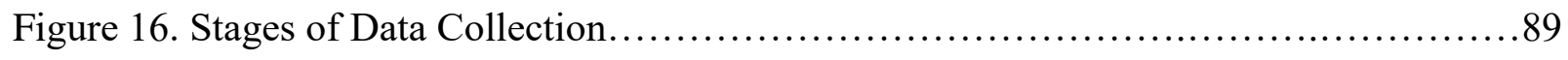

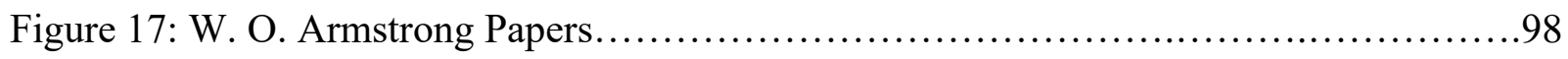

Figure: 18 Finding with most agreement by participants.................................103

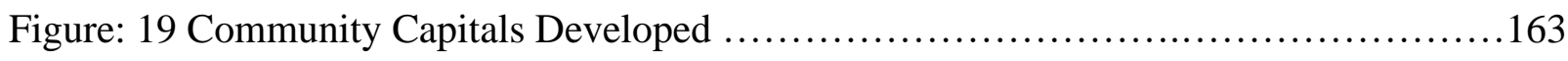




\section{Chapter One: Introduction}

Marginalized communities have frequently been studied by social scientists and have been the subject of community development efforts. Despite such efforts, many marginalized communities continue to fall behind. Differences between these communities are in terms of infrastructure, educational opportunities, fragmentation, leadership/governance, recreation, fear of change, facilities and other amenities, and opportunities (Dale \& Newman, 2008; Robinson, 2004).

Why is it so difficult to change the trajectory of many marginalized communities? The answer to this rhetorical question is multi-faceted and requires collaboration, partnerships and access to resources and funds, which are way beyond the reach of struggling communities. This research seeks to find at least partial answers to this question from the study area. The researcher believes the answers are in part related to the roles played by community members and their involvement in the community development process. Therefore, this research will investigate how community members perceive their roles and influences on decision making. Insights gained from the research will be useful to practitioners - volunteers, professionals, and community leaders engaged in community development activities.

The research relies on community members for information about how they perceive their experiences and roles through interviews and focus group meetings. This approach requires expertise in survey research and interviewing techniques. The research relies on data from studies in community development literature and related disciplines. Definitions and principles of community development used are drawn from Community Development Society (CDS), United Nations (UN) and interdisciplinary insights to put the study in perspective.

For a common interpretation and uniform understanding of principles, approaches, application and desirable outcomes, researchers (i.e., Anglin, 2011; Nabatchi \& Leighninger, 
2015; Brenman \& Sanchez, 2012) recommend practitioners to harness factors and elements that are relevant and applicable to each community. For instance, an approach that relies on experts may be less open to involving community members in decision-making than a participatory approach. In the same vein, principles may be similar across the community development field but may provide different outcomes across areas of application.

Also, an expert's interpretation, framing and application of community development principles like empowerment, participation, inclusion, equality of opportunity and antidiscrimination, and leadership need to be thoroughly and contextually checked for suitability before embarking on a community development process. This is so because the success or failure of initiatives depend on how these parameters are effectively utilized.

Therefore, the thrust of the study is to trace and identify these different factors as they play out in the named case study. This community is the Westside neighborhood in Fairmont, West Virginia. The neighborhood will be examined in relation to the historic experiences of its residents with one another, the role played by Dunbar School, which was a segregated African American school serving the neighborhood, and what changed when the school was closed. Also, the relationship between residents and community development agents coming to their community, organizations in the community, the leadership and the city council government will be explored. Lastly, the current neighborhood situation will be described, and projections will be made on what the future holds for the neighborhood based on findings of the research.

\subsection{Background}

The case study area is the Westside neighborhood in Fairmont, West Virginia. This was a mixed neighborhood of predominantly Italians and Polish working-class migrants in the early 1920s. The demography continues to change as most Whites move away and blacks moved in to 
produce what is today a segregated and marginalized African American neighborhood, interspaced with other races. The community is defined by five neighborhoods by residents, Maple Avenue, Jackson Addition, Shadyside, Bellview and Sterling Heights. In 2013, the population in Census Tract 205, which constitutes the study area was 40.3 percent African American, but this has dramatically reduced to 29.0 percent at the time of this study. More detail on Fairmont and the Westside neighborhood is provided in the Case Study Area section.

Westside was once bustling with social and economic activities. Immigrants from the Southern U.S and Europe settled here starting in late $19^{\text {th }}$ century and contributed to the neighborhood's growth and development. For a prolonged period, the coal industry was one of the economy's pillars, but the relatively sudden and dramatic shift in coal mining employment starting in the early 1950s (West Virginia Office of Miners' Health, Safety, and Training - WV OMHS\&T $-2003^{1}$ ) led to a steady decline in economic, social, educational, and infrastructure development. Although many West Virginia communities - and the state as a whole - suffer from economic, social, and demographic decline, there is a perception by residents that perhaps Westside could have been an exception if certain issues affecting the community had been handled differently.

Hope for a better life was the primary motive of those who initially settled in this neighborhood - the search for a home, the pursuit of education, and to earn a living to support themselves and their families (Stout et al., 2015). As time went by, Westside became a unique location with significant development that propelled the neighborhood to be one of the most sought-after places in the city for business, education, economic, and social life. Today Westside still is home to many residents, including African Americans.

\footnotetext{
${ }^{1}$ The website provides coal mining employment data from 1863 through 2013. 2003 is the site's copyright date.
} 
However, socio-economic conditions in the neighborhood are in sharp decline, which has caused some residents to move elsewhere. Today, a once vibrant neighborhood has become a shadow of its former self. A major factor responsible is the decline of the coal industry, which was once the economic mainstay of the whole region. In response to the downward trends in Westside, different community development initiatives have been tried, but without appreciable lasting success.

Consequently, the researcher uses the summary of a 2017 report of a revitalization development initiative, led by a West Virginia University Professor Margaret Stout and a group of students of which the researcher was a part of, as a starting point for the research. The development initiative was led by West Virginia University in collaboration with the Fostering Fairmont Project out of which Westside Action Coalition (WAC) was created. The initiative was a four-semester service and learning project that attracted the following partners: Fairmont City Partnerships, National Association for Advancement of Colored People (NAACP, Fairmont Chapter), and the Fairmont City Council. The focus of the two-year effort was on restoring trust between community members and rebuilding social capital, as well as developing collaborative ties with other associations.

The development of the neighborhood profile took up the first semester. The profile focused on community assets, such as natural, cultural, human, social, political, and organizational and the built environment. During the second semester students in this service and learning project presented their findings to Westside residents in a series of events. They used community engagement techniques, including a design charrette (a brief collaborative gathering of residents during which members share diverse development ideas through sketch designs) to bring people together and encourage their participation and support. The community engagement meetings 
produced ideas that became part of the third semester planning effort. This planning stage saw residents collectively come up with short-term and long-term projects for their community. The fourth semester was the last phase and was labelled "sustainability." Participating students were assigned to the eight projects selected by the residents. The idea was for each group to come up with plans and a strategy on how to realize these projects.

Each project was allotted a liaison to coordinate efforts and manage information flows. A general liaison was nominated to foster communication among all eight projects. To a large extent, the outreach effort was considered a success by some residents, when compared to previous revitalization efforts in the community. Reasons cited for the success of the project include the partnership with West Virginia University, residents involvement and participation.

The major lesson learned from this outreach effort is that expectations must be discussed, evaluated, and agreed upon before work on a project starts. Because of differences in expectations among project participants, some residents showed some reservations because, in their opinion, most of the issues affecting their community had not been identified, connected with, and addressed appropriately. As a result, relationships and trust between residents, city government and development partnerships deteriorated. When there is little to show for previous development efforts, and residents suspect that their community is being used to meet someone else's agenda, preconditions for a successful development effort are absent. At the same time, it is unrealistic to expect that problems that developed over many years can be addressed in just two years by students supervised by faculty. The experience in Westside underlines the importance of assessing the readiness of a community for a collaborative effort in a development project. In addition, community expectations need to be clarified before the project starts. In the case of a service and 
learning project, expectations must respect the limited experience of student participants, and constraints imposed by academic calendars and student and faculty resources.

In addition, it could be deduced from above that communal trust-building should be a priority for future interventions to achieve sustainable success. To succeed with trust and relationship building, it is necessary to first explore Westside's history because the neighborhoods strong initial foundations of trust and tightly knit relationships were eroded by past events. Based on interviews of and meetings with residents, the researcher learned that the now closed Dunbar High School was the center of the community. The high school was closed in 1955 as part of reorganization due to desegregation.

Conversations with residents between 2015 and 2018 revealed that the neighborhood never found a replacement for Dunbar school as a center of leadership, unity, values, morals, education, and economic, social and cultural life of Westside. As residents indicate during pilot study, this needed replacement may not need to be a school, but it could be something that serves the interest of residents and will garner their support.

However, from pilot study conversations, it would not be too far from truth to assume that issues in the Westside are tied to race, although historically, intra-racial, colorism, class, and supremacy issues have highlighted intersecting forces adding to challenges in the neighborhood. Jackson-Lowman (2013) defines colorism as:

a form of oppression that is expressed through the differential treatment of individuals and groups based on skin color. Typically, favoritism is demonstrated toward those of lighter complexions while those of darker complexions experience rejection and mistreatment... (p. 28) 
Many early Westside residents were Blacks from the southern U.S. and Italians and Polish immigrants. This allows a historical comparison between Italian and African American parents. While the immigrants were able to align their children with legitimate businesses and ways of life, African American parents were less able to initiate their children into legitimate jobs, trades or businesses. Popular jobs available to African Americans were lift or elevator operators in shops or mine fields (Stout et al., 2015). A possible hypothesis to explore is if the inability of African American families to prepare their youths for the future played a significant part in setting the neighborhood on the path that led to its current state. The other is also if their inability was forced on them by societal norms outside of their control (segregation and desegregation). If the latter is the case, as it appears from every indication, then it pays credence to the notion of "double consciousness" as illustrated by Du Bois (1903). Du Bois lamented the situation of African Americans in American society, who were divided between dual identity, and had to depend on another peoples' approval to live their lives.

\subsection{Community Development}

In a general sense, community development concerns itself with social, economic, demographic, health, education, and capacity issues. It is both a profession and field of study that has changed and evolved over time in response to needs, experience, and research. In the U.S., the Community Development Society (CDS, founded in 1969) is dedicated to the study of community development. Alongside with CDS, the National Association of Community Development Extension Professionals (NACDEP) is similarly dedicated to practice. Because of their accomplishments, their definition of community development is appropriate for this study. In addition, a few other definitions are considered to highlight agreements and disagreement. 
CDS Definition: Community development is a profession and academic discipline that promotes participative democracy, sustainable development, rights, economic opportunity, equality and social justice, through the organization, education and empowerment of people in their communities. (CDS and NACDEP, 2017)

\section{Other Definitions:}

Wise (1998) summarized multiple definitions of community development to further enhance understanding of community development. Five of them are described in the research:

The deliberate attempt by community people to work together to guide the future of their communities, and the development of a corresponding set of techniques for assisting community people in such a process. (Bennett, 1973, p. 80)

All of the efforts made to establish and maintain human interaction while improving the appropriateness of the physical setting to that interaction. Underlying values to this development are the recognition of the individual's right to select the extent of community or privacy and the group's right to identify its own needs for community development. (Koneya, 1975, p. 54)

Shaffer (1989, p. 18) Community as used here is a group of people in a physical setting with geographical, political, and social boundaries and with discernible communication linkages. Development is a multi-dimensional concept that incorporates more than just market values; it includes concern about equity and well-being and the community's ability to adapt to change. The terms "vitality" and "development" are thus almost synonymous. Acts by people that open and maintain channels of communication and cooperation among local groups. (Wilkenson, 1979, p. 11). 
A common theme is the idea of involvement to elicit participation from community members. Brenman and Sanchez (2012) refer to "involvement" and "participation" as conduits for communication and information exchange, which is the foundation of an inclusive process. The authors recommended a framework that includes information and analysis, continuity, transparency and integrity in a development process.

The researcher uses the CDS-NACDEP definition because it applies to development practitioners as well as community residents, and it combines theory and practice. In this, the researcher will show how to translate this definition into practice and action.

All seven definitions presented here list inclusiveness as critical to establishing the bond and trust necessary for an effective development process. Unfortunately, this is one area where many community developments processes have failed, particularly during implementation phases. For example, "inclusion" could mean funders/developers inviting just a few people, and dictate plans to the residents, without necessarily asking for their input. The results are not always palatable, and there are many examples that should serve as cautionary tales in the United States and elsewhere (Associated Press, 2013).

One of those cautionary tales is from a community in Southwest Nigeria that needed water. A development organization came to assist, but instead of working with residents to ascertain what need was pressing to them, they assumed that what the community needed was an amusement park. Although this was desired in the community, it had not a high priority among the residents. Consequently, the amusement park, though beautiful, did not help the community. The moral from the example is the importance of understanding the position a community is in before attempting to help. 
A final definition worth mentioning is one postulated by Flora et al. (1992). They opined that for community development to occur, people in a community must believe that working together makes a difference and that they must organize to address their shared needs collectively. This is in line with the United Nations (2010) definition, which refers to the process as local communities coming together to improve their standard of living and quality of life.

For this study, the researcher selected the following key words in each definition to serve as reference words: empowerment, participation, inclusive, social justice, equality, capacity building, self-help and trust. These are common words that characterize the definitions by the different authors above.

This definition implies a bottom up approach that is focused on improving the general wellbeing, as advocated for by Shaffer et al. (2006). The need for continuous search for impactful change and interdisciplinary and collaborative efforts in addressing human and community needs should not be compromised because of personal or group interests. These needed changes, as Shaffer and collaborators pointed out, are usually brought about by either seeking a completely different route or a re-examination of the concepts and methods that accommodate diverse perspectives from within various fields in the community, and help the society to better understand process, and be in a position to contribute to its success. It also speaks to the fact that it takes different elements from within the community to come up with an effective community economic, social, political, educational and developmental plan, instead of sticking to only known traditional approaches.

Shaffer calls for a different specification for addressing problems of each community to come up with collective approaches for finding solutions. In the process the investigators come to understand the community's social, human, economic, political, built environment, physical, and 
cultural assets. In addition, paying attention to understanding the community leads to insights into politics and power dynamics that influence the community and its residents. This is important because there is no one-size-fits-all approach and method for addressing community issues (Boone et al., 2008).

Finally, since advancement in technologies do not produce equal access opportunity to communities, positive changes in struggling communities can only be achieved by bridging the gap between theory and practice. What then constitute attributes of a successful community development? The summary by Litwin et al., (1994) informs this study.

...characteristic of a successful community development effort is that the sum of the efforts is greater than the parts: the neighborhood as a whole looks, feels, and acts different to everyone who lives, works, and visits there. Not only are many of poor families' immediate needs met - decent, affordable housing, access to job training and education, nearby health care, and so forth - but momentum has built within the neighborhood that enables the people within it to sustain and build on the changes that have occurred. The neighborhood has become a community increasingly controlled by the people who live in it. (p. 3)

Therefore, this study will identify and analyze what problems most negatively affect Westside residents, using their stories and experiences. Findings will also form the basis for conceptualizing and designing community development interventions. Recommendations based on the research findings will provide the basis for future community-driven revitalization activities. 


\subsection{Theoretical Framework}

Structural functionalism, conflict theory and symbolic interactionism are traditional theories that have been used in community development. While these are useful theories, the framework of this study is critical theory.

Critical theory is a social theory with roots in the Marxist tradition; it seeks to unite theory and practice (Molyneux, 1983). This theory was developed in the 1930s by scholars of the Frankfurt School, including Horkheimer, Adorno, Marcuse, and Benjamin. These scholars were motivated by concerns that traditional theories were insufficient to explain the development of capitalism and socialism. They came up with critical theory, which is oriented towards critiquing traditional theories and society. A theory is described as critical when it seeks to liberate human beings from the circumstances that make them feel less or perform worse than others (Horkheimer, 1982).

Horkheimer (1976) described critical theory as both a practical and normative way of thinking, that can explain what is wrong with current social reality, identify actors to change it, provide norms for criticism, and goals for the future. In his view, critical theory must account for the whole of society in a historical context and offer a holistic critique. The interdisciplinary quality of critical theory makes it suitable for most areas of study in the social sciences and education. Horkheimer cautioned, however, that there are no general criteria for judging critical theory because it is based upon the recurrence of events, unlike traditional theories, which he referred to as theories of the status quo that function only within the present order. Critical theory asks questions about what was, what is, and what ought to be or should be. It is concerned with the ontology, epistemology and methodology of reality (Crotty, 2015). 
To apply critical theory in the Westside neighborhood we need to understand the historical, social, economic, educational, racialized, leadership-oriented, and other realities. A process using critical theory helps discover the history, mindset, views, experiences, priorities, and above all, the residents' perspective on how to achieve positive change. Traditional approaches to community development have often failed to produce success because of their neglect of history and community-specific conditions. Horkheimer (1976) suggested that practitioners and scholars should step away from traditional theories because the future of humanity depends on critical attitudes towards traditional ways of looking at societal issues.

Freire (2000) is another influential voice who draws on critical theory to advocate for a society and culture that will lead to the exoneration of both the oppressed and the oppressor. Factors responsible for silencing people facing oppression and injustice include lack of knowledge of how to effect change. Freire cautioned that there should not be a communication barrier between authority and people. The existence of barriers is often the result of policies that establish obstacles to the education of members from marginalized groups.

To liberate a people, those in positions of authority, such as community development practitioners and leaders at all levels, must learn from those people, associate and mingle with them, to bring about positive change.

This kind of approach to community development permeated the work of Freire. He was concerned about the liberation of the entire human race, not just the oppressed, because in Freire's views, the oppressor and the oppressed live in conditions that are not healthy. Such unhealthy conditions, he believes, could be healed by working collectively towards common goals and objectives. Freire demonstrated the principles he advocated when he taught over 300 sugarcane 
farmers to read and write in just 45 days in Brazil. Around the world, his approach has been replicated and produced remarkable results.

Given this backdrop, this framework is suitable for this study because of the trajectory of racial segregation, desegregation, school closing and the general historic events that left many unanswered questions in the Westside neighborhood. Critical theory is superior to other traditional theories for this study because it is relevant to probing and understanding the lived experiences and race relations that have shaped the views and perceptions of the residents. This is so because critical theory seeks to ask pertinent questions and is able to elicit candid responses. As Jackson (1985), puts it, "this theory will help to convey the inner life and texture of the diverse social enclaves and personal circumstances of societies" (p.18). Jackson based his views on facts he accumulated from social systems where there were disparities in power and resource beyond the reach of the individuals who create and sustain them.

Informal conversations with residents have shown that the relationships between people in the neighborhood, associations, businesses, and government agencies, have not been the same after the closing of Dunbar School in 1955. Critical theory allows asking challenging questions and looking for explanations among historical issues, such as the decision not to include African American teachers and mentors of African American children when school systems were desegregated (Walker, 1996). Again, the purpose of this study is to understand residents' perceptions, views, and experiences, as well as to explore alternative approaches to community development based on local insights. 


\subsection{Problem Statement}

The number of marginalized communities continues to grow in West Virginia (Eisenberg, 2016) and has left many communities with fewer people and weakened economic and social activities. Therefore, an urgent need exists for an approach to revitalize diminishing communities.

\subsection{Study Questions}

Listed below are study questions:

- How have race, segregation, and desegregation influenced relationships and trust among residents?

- How have past experiences shaped leaders in the neighborhood?

- How have residents' perceptions of discrimination shaped the neighborhood's relationships with city government?

- What was the impact on the Westside community when the role of Dunbar School changed after desegregation with regard to education of the youth, social and cultural life of the community?

- What have been the impacts of community revitalization initiatives in the neighborhood?

\subsection{Objectives of the Study}

This research aims to:

* Gather information to understand how the neighborhood's history from residents' perception of their past and looking into the future.

* Identify obstacles to human and community development as a result of past historical experiences.

Give residents the opportunity to express their opinions and participate in the development process. 
To use the information to initiate appropriate, inclusive and community-oriented development initiatives.

* Leverage the strength of internal forces and agency in community development.

\subsection{Rationale}

Having worked/studied in the Westside neighborhood for over two years, one comes to realize that the residents' perception of their history continues to shape their understanding of their environment. Past development initiatives, aside from the Fostering Fairmont Project, have not effectively included residents in the planning to understand their ideas and vision. Consequently, they have not been very successful.

A lack of understanding of the residents' aspirations, was evident when a city manager commented at a community briefing meeting, that residents should forget about their past so that they can move on with efforts aimed at the future. Silence filled the hall after the comments and residents were whispering disagreement to one another. Their disapproval was expressed even more clearly as attendance at future meetings declined. To get people involved, they must be able to express their views and share their stories of the past that influence their aspirations for the future.

Therefore, to address such past shortcoming, this study seeks to:

- Gather experiences of Westside residents.

- Solicit their ideas for development projects.

- Assess residents' ability and willingness to contribute to development efforts.

- Guide future development organizations on how to approach community development in this specific neighborhood. 


\subsection{Definition of Terms}

It is usually important to highlight definitions of important key words used in a research study of this nature to help readers understand the significance of each word or phrase used in a particular context. This is the aim of this sub-section.

Community- a process of collective action expressing the solidarity of the local population. The locality, the local society and the field of community interaction (Kaufman, 1959).

Desegregation- Keeping of Whites and Blacks together.

Development- a process of improving the well-being of people (Wilkinson, 1981).

Leadership- Leadership is not about titles, positions or flowcharts. It is about one life influencing another (Maxwell, 2009).

Marginalization- is both a condition and a process that prevents individuals and groups from full participation in social, economic, and political life Alakhunova, et al. (2015).

Resilience- the ability of individuals, households, communities, institutions, nations, or even value chains and ecosystems to withstand crises, recover from them, and adapt so as to better withstand them (USAID, 2012).

School Closure-Relocation or movement of students from one school to another.

School Closing- Shutting down of school.

Segregation- Keeping of White and Blacks separate.

Sustainability- sustainable development is development that meets the needs of the present without compromising the ability of future generations to meet their own needs (World Commission on Environment and Development, 1987). 


\section{Chapter Two: Case Study Area}

\subsection{Regional and Local Identity}

Fairmont is located in North Central West Virginia. It was named "fair mount" for its beautiful overlook of the confluence of the West Fork River, Tygart River, and Monongahela River. These rivers are linked to the city's identity and divide its neighborhoods. From the 1800s navigable waters, early railroad development, and resource extraction contributed to a bustling economy. Industries included glass, natural gas, bituminous coal, timber, and railroad and river transport. These industries, coal chief among them, provided jobs to European immigrants and African Americans migrating from the South.

Table 1 below depicts the population growth of Marion County from 1930 through 2017. The current growth rate is $-0.25 \%$ with 56,337 people residing in the county. Marion County is the $11^{\text {th }}$ largest county in West Virginia, with a total area of 312 square miles consisting 309 square miles land and 2.8 square miles water. The racial makeup is White $94.0 \%$, Black $3.6 \%$, two or more races 1.4\%, Asian 0.7\% and American Indian and Alaska at 0.1\% (US Census, 2017 ACS 5Year Survey).

In 2017, there were 23,652 households, and 15,510 families in Marion County, with a per capita income of $\$ 28,737$ (West Virginia: $\$ 24,478$ ). Major employers in the city or within commuting distance include Fairmont State College, Fairmont General Hospital, Consolidation Coal Company, Eastern Associated Coal Corporation, Walmart Stores, Inc., Ruskin Manufacturing (closed in 2013), Allegheny Power Service Corporation, and Aegis Communication Groups. Residents from this county also commute to work in neighboring counties, particularly Monongalia to the North and Harrison to the South (US Census, 2016). 
Census data show that in $2015,8,797$ county residents commuted to work in other West Virginia counties, or more than one-third of all employed county residents. This is one of the highest outcommuting rates in West Virginia. Table (1) shows the population and growth rate of Marion County between 1930 and 2017. Marion County's population less since it peaked in 1950 exceed that of the state by a factor of two.

Table 1. Marion County, West Virginia Population 2019

\begin{tabular}{r|rrr}
\multicolumn{1}{c}{ Year } & Population & Growth & Growth Rate \\
\hline 2017 & 56,337 & -140 & $-0.25 \%$ \\
2016 & 56,477 & -213 & $-0.38 \%$ \\
2015 & 56,690 & -32 & $-0.06 \%$ \\
2014 & 56,722 & 71 & $0.13 \%$ \\
2013 & 56,651 & -76 & $-0.13 \%$ \\
2012 & 56,727 & 78 & $0.14 \%$ \\
2011 & 56,649 & 115 & $0.20 \%$ \\
2010 & 56,534 & -715 & $-1.25 \%$ \\
1990 & 57,249 & $-8,540$ & $-12.98 \%$ \\
1980 & 65,789 & 4,433 & $7.23 \%$ \\
1970 & 61,356 & $-2,361$ & $-3.71 \%$ \\
1960 & 63,717 & $-7,804$ & $-10.91 \%$ \\
1950 & 71,521 & 2,838 & $4.13 \%$ \\
1940 & 68,683 & 2,028 & $3.04 \%$ \\
1930 & 66,655 & 12,084 & $22.14 \%$ \\
Courtesy: US Census, 2017 ACs 5-Year Survey & & \\
\hline & & &
\end{tabular}


Figure 1. Location of Marion County

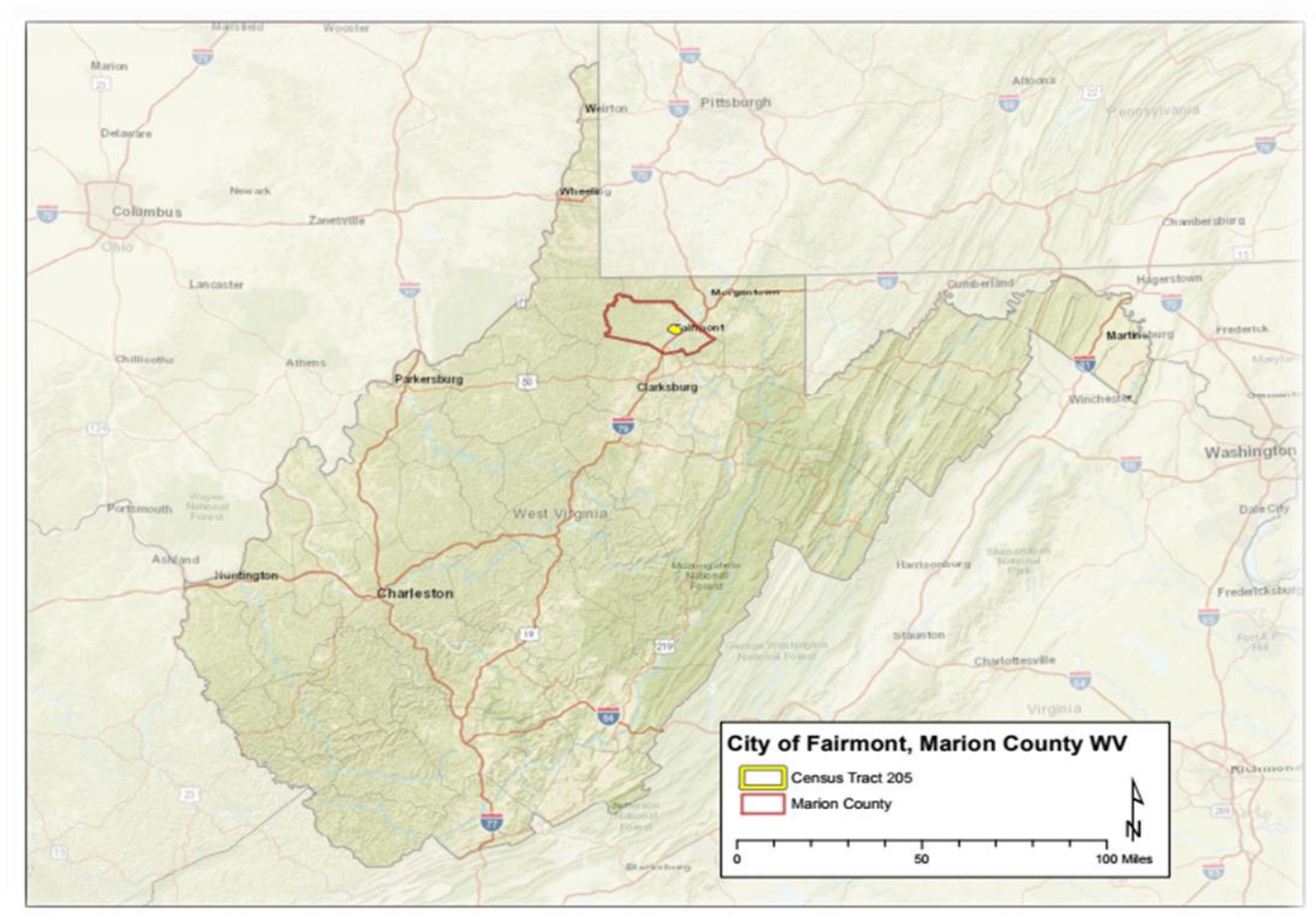

Courtesy of Jackie Strager, 2017

Fairmont's historic downtown district preserves hundreds of structures that provided economic and social life to neighboring communities. It was established as Middletown by the Virginia legislature on the farm of Irish immigrant Boaz Fleming on January 19th, 1820. He parceled off his 254-acre farm and sold the lots to form a new town. The city became Marion County's seat in 1842 and its name was changed to Fairmont in 1843 (Stout et al., 2015). 
Figure 2. County Map with Major Roads. (Marion County is highlighted; Census Tract 205 is shown in Figure 5 below.)

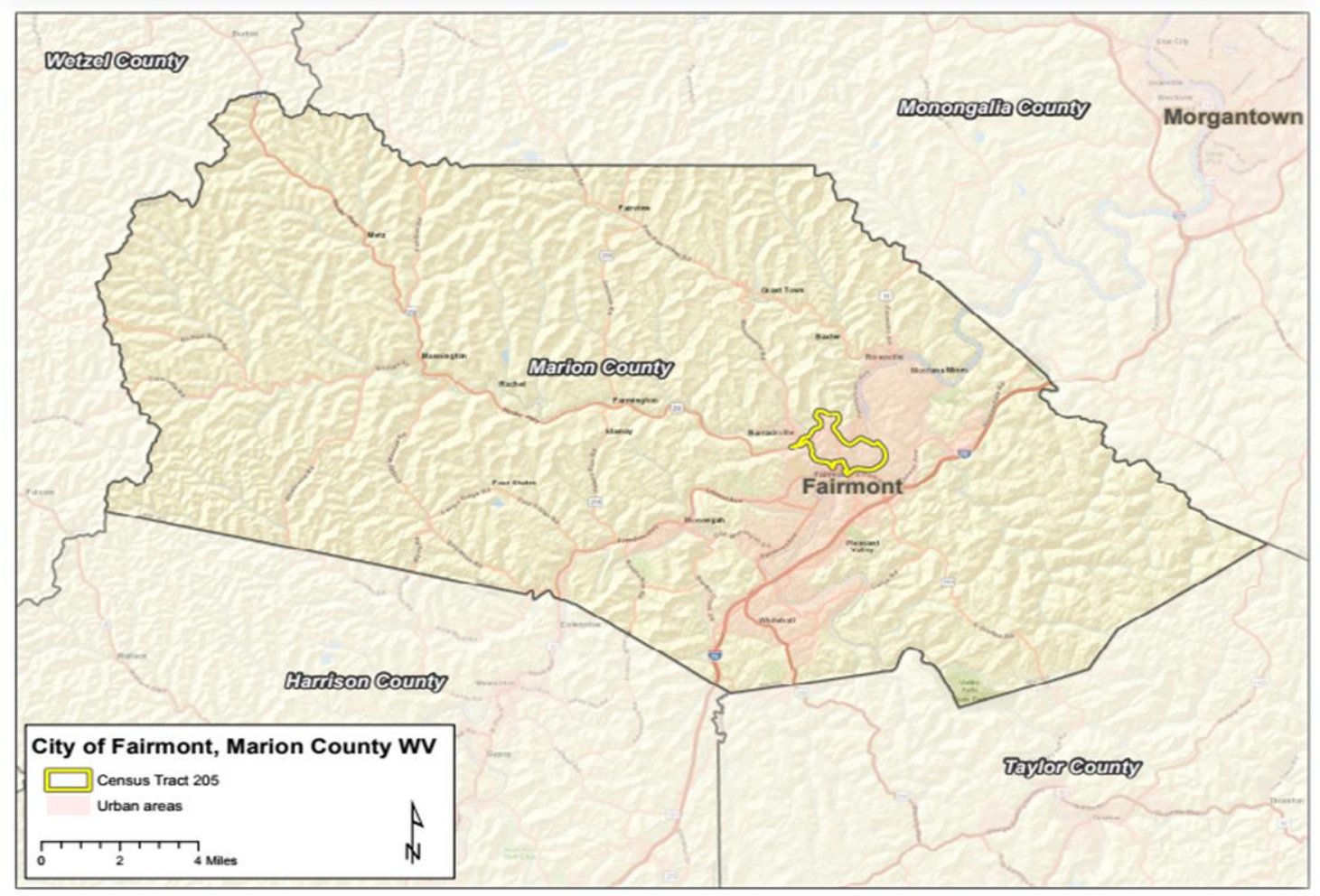

Courtesy of Jackie Strager, 2017

Fairmont has a long history of immigration. After the Civil War, in the late 1800s, many African Americans migrated from the south to West Virginia to work in the coal industry. The presence of industry also attracted European immigrants in large numbers. Many Italian, Irish, German, Russian, Hungarian, Belgian, Greek, and Austrian immigrants came in response to World War I to become useful hands in the flourishing business activities in Fairmont. There were also experienced miners recruited from England and Wales to teach and support local coal mines (Stout et al., 2015).

Businesses flourished in Fairmont, with Monongah Glass, The New Owens-Illinois Glass, and Westinghouse Electric prominent among them. The town was the headquarters for Fairmont 
Coal Company and later for the Mountaineer Coal Division of Consolidation Coal Company. Today, it is the home of Fairmont State University and two high schools. Cook Hospital was formed here, and eventually became Fairmont General (Koon, 2013).

Figure 3. Percentage Racial Population Distribution in Fairmont (Outer Circle) and Census Tract 205 (Inner Circle).

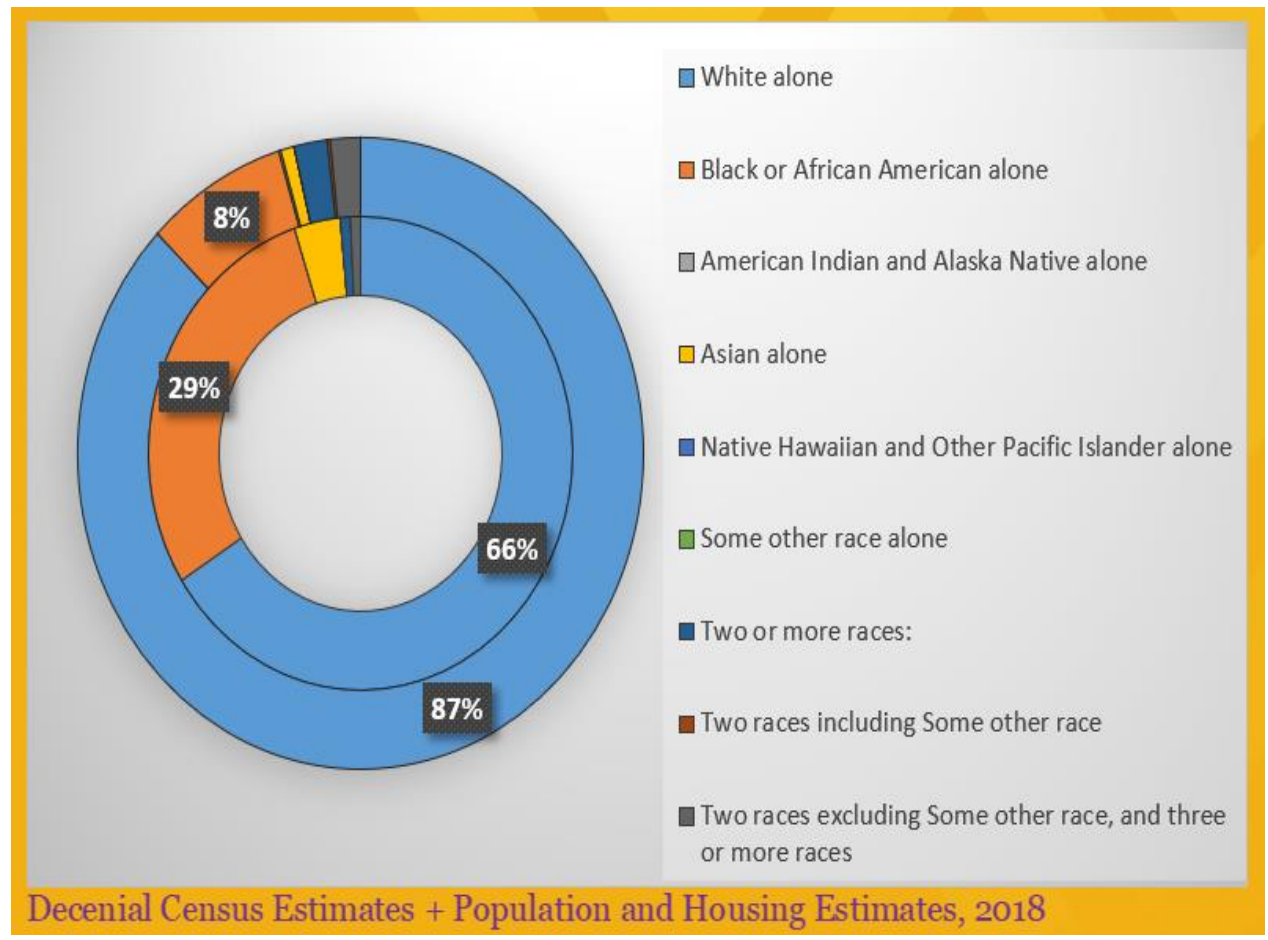

Coal remained a source of employment for many African Americans and European immigrants, but the industry suffered from economic problems following World War I and later, the Great Depression. During the late 1970s, the coal industry suffered a severe recession and unemployment reached all-time highs (Koon, 2013). This resulted in a population decline in Fairmont from the high of 29,346 in the 1950s to 18,622 in 2016 (U.S. Census, 2017).

African Americans and members of other group left Fairmont and the state in large numbers to seek better economic opportunities elsewhere. This movement out of the region and 
state continues to be of concern. The city and state governments and well-meaning individuals and groups have adopted strategies to reverse decline and attract businesses and people from elsewhere. These include the revival of the downtown, and restoration of a historic high-level bridge and the Marion County courthouse. There were also major investments on the city's outskirts, including the Fairmont Technology Park, NASA, Lockheed Martin Corporation's BEACON Facility (Biometric Experimentation and Advanced Concept Center) and NASA's Independent Verification and Validation Facility, located along the I-79 south corridor.

Figure 4. African American Population Percentage, 2013 and 2018.

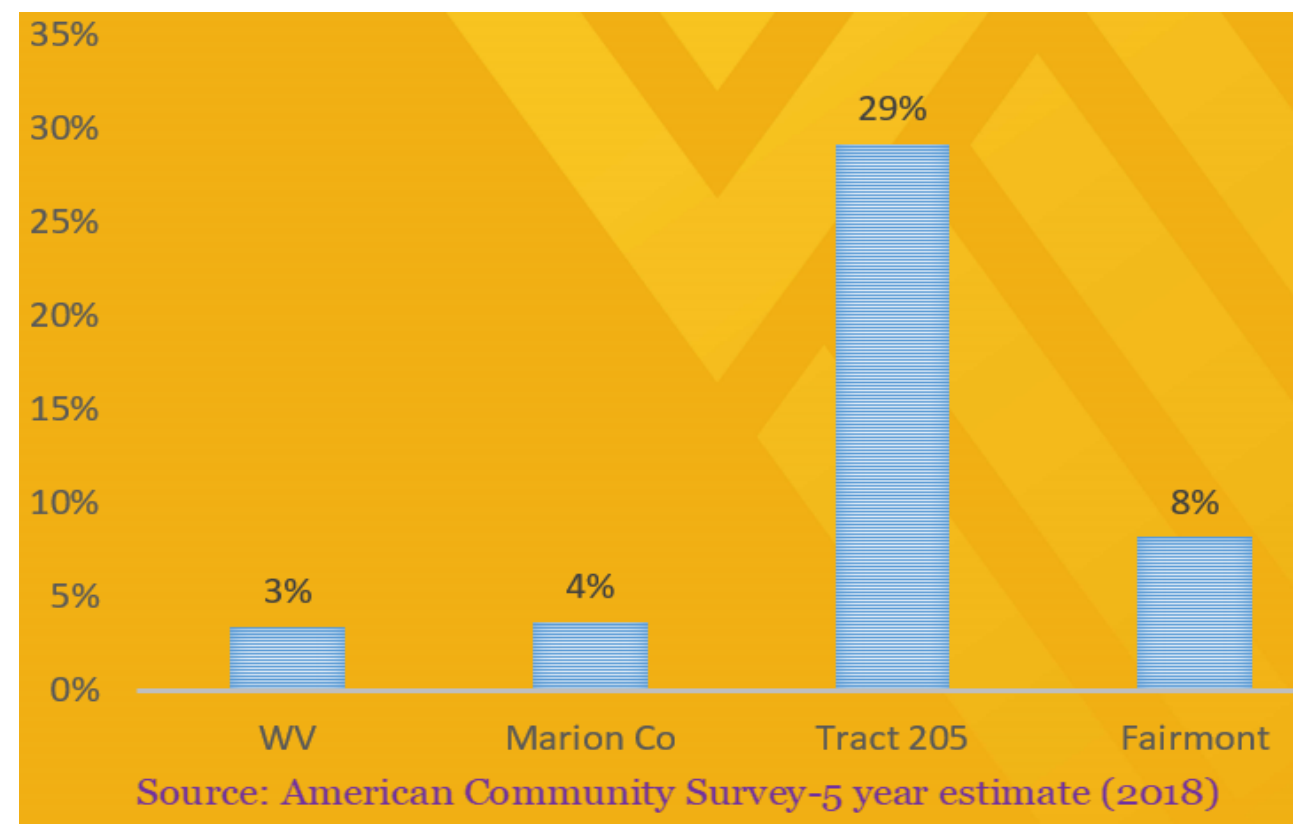

Fairmont's attractions include the way the past has shaped the city and, over time, formed a community. Specific attractions include Prickett's Fort State Park, Marion County Historical Society Museum, and the Mon River Trail. Signature events in Fairmont include the Feast of Seven Fishes in December, which chronicles the celebration of Christmas in the Italian tradition, and the Johnny Johnson Blues and Jazz Festival, which is an annual music and food event held every July. 
Figures 5 \& 6. Neighborhood Maps and Landmarks with Aerial Photo in the Background (Centered on Census Tract 205).
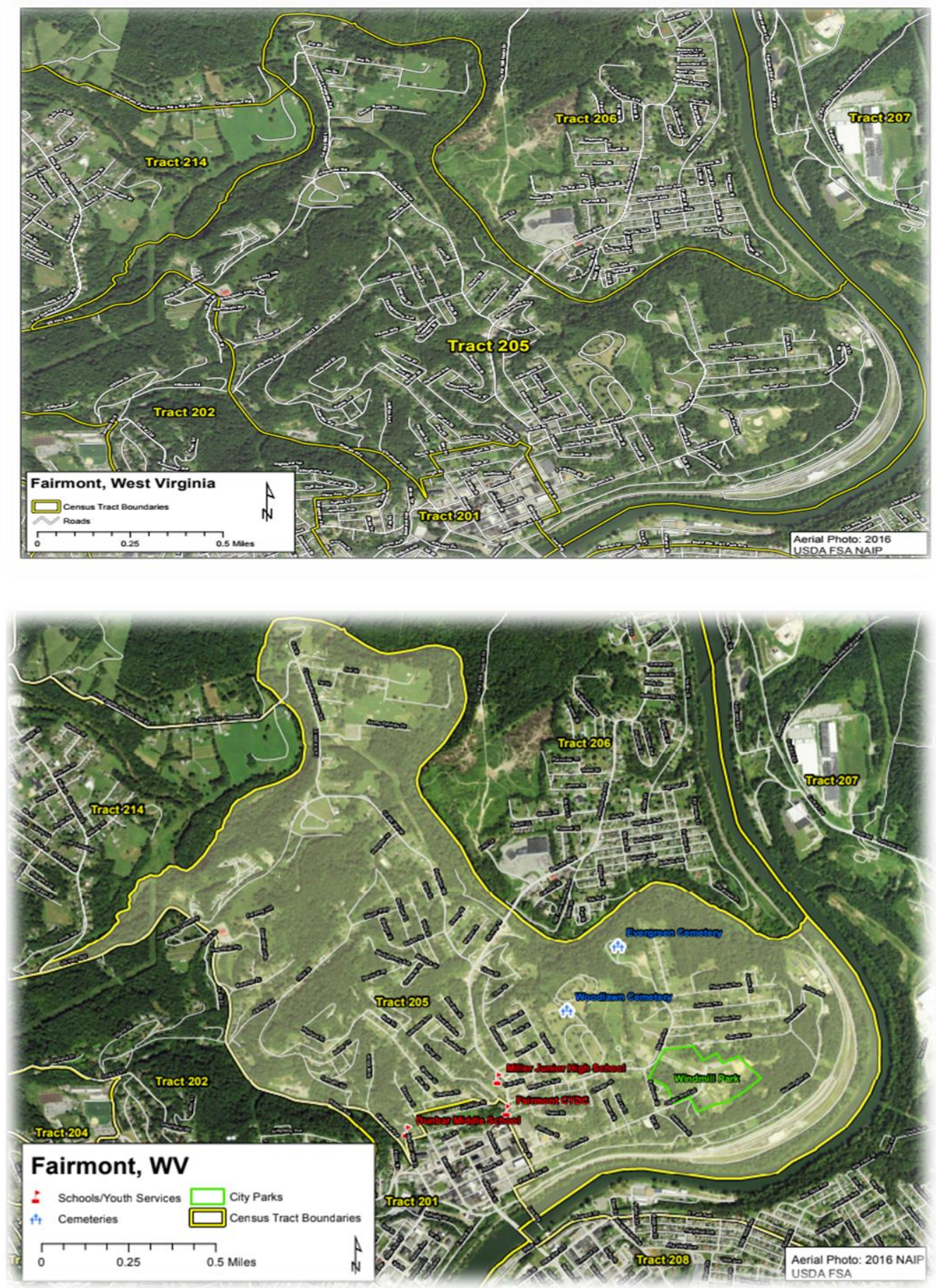

Courtesy: Jackie Strager, 2017 
Census Tract 205 includes a significant percentage of Blacks/African Americans. The communities that make up this tract include Maple Avenue, Jackson Addition, Shadyside, Bellview, and Sterling Heights. Figures $5 \& 6$ show the landmarks in the community in to include Woodlawn Cemetery, Evergreen Cemetery, Dunbar School, Fairmont City Youth Development Center and Miller School. The Westside neighborhoods of Fairmont has a unique history. Stout et al. (2015) conducted a community profile of the neighborhood that provides a glimpse of the many community assets that are present within the neighborhood. A community or neighborhood with similar assets should have a very good chance of having a successful community capacity building or development process (Flora \& Flora, 2007).

One of the most valuable assets of the neighborhood is its land. This constitutes the topography, soil quality, climate, open spaces, natural resources and environmental quality. The quality and potential for current and future development of this land has witnessed a tremendous past development taking place in the neighborhood. Some of the built assets are Dunbar School, Woodlawn Cemetery, Windmill Park, Miller School and Evergreen Cemetery. These assets used to have significance in the lives of the people, especially Dunbar School and Windmill Park.

How does the land benefit residents in the present compared to the past, and what could the benefits be in the future? Mineral extraction occurred in the past in the Jackson Addition and elsewhere in the neighborhood, and those activities left an indelible mark. A gully created in the Jackson Addition is increasing and poses a danger to residents.

Woodlawn Cemetery is listed in the National Register of Historic Places. It was established in 1875 and encompasses about 15 acres. It is the burial place of Governor F. H. Pierpont (18141899) and his wife, and other individuals of importance to Fairmont and beyond. Until recently, 
the cemetery was reserved for Whites only. Black folks buried their dead in the adjacent Evergreen Cemetery (Stout et al., 2015).

Windmill Park is another neighborhood asset. The park includes a playground, picnic tables and grills, electric outlets, a baseball field, basketball court, football field, and a concession stand. It is located at 900 Ogden Avenue in the Jackson Addition and continues to serve as the Westside community's primary venue for outdoor social and recreational activities. Historically, the park was managed by neighborhood residents. Over time, it was also used for illegal activities like drugs trafficking and even homicides (Stout et al., 2015).

At some point, this community that once was, to a large extent self-reliant and sufficient, with robust social and economic activities, allowed to deteriorate. Today, they are receiving some attention from the city government and interested groups. It remains to be seen if such efforts will succeed to reverse the effects of past neglect which drove residents to focus on their personal space, curtailing collective activities and diminishing neighborhood spirit (Brooks, 2017). This is to say that the neglect of community assets such as natural, cultural, political, social and built (Emery \& Flora, 2006) contributed to the erosion of community human and social ties, as well as social ties between residents and visitors to the neighborhood. 
Figure 7. Population Change in Fairmont from 1970 through 2016.

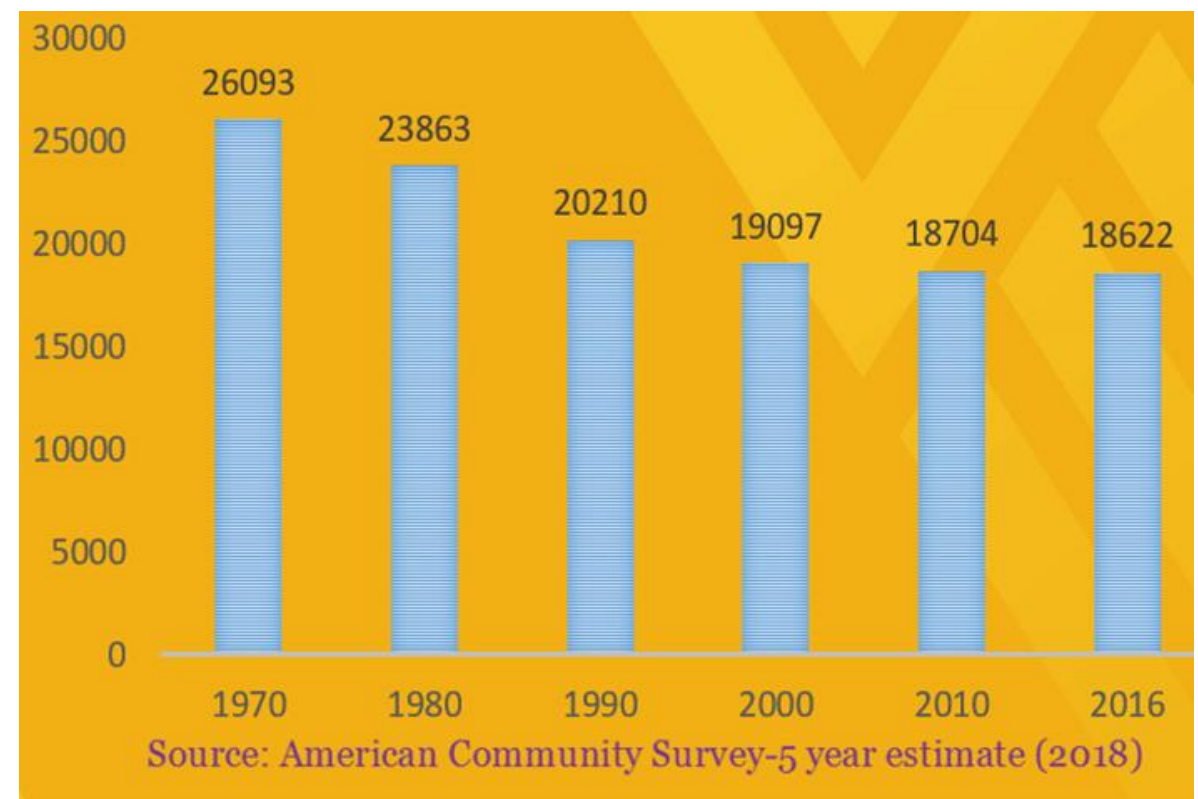

\subsection{Social and Economic Activities}

The social and economic history of the Westside is tied to immigrants who came from Europe and the south. As expected, these people brought with them their cultural heritage and that was merged in the new location to form something new.

Census Tract 205 has a significant African American community. Many of them migrated from the South and have a unique way of approaching life issues (Koon, 2013). Nembhard (2015) captures this:

While the powerful are gaining more and more power over the centuries, they're also leaving holes and gaps so that the people who are exploited are figuring out at least small ways to do alternatives. Even if we take enslaved African Americans as an example: people who didn't own their own bodies, didn't own their labor, weren't paid — were totally exploited. Yet, on the one 
day they had off, on Sunday, they would farm small gardens together. Some actually hired themselves out if they had skills. They found alternative ways to make sure they could feed their families and have some dignity (p. 15).

This was the historical situation of Blacks, which influenced their world view. It is important because it captures how they strategized by working together and helping each other to deal with difficult situations. They were able to do this through mutual respect, supplementing their income with part time jobs, engagement in small businesses and giving of their time and resources to move their communities forward, especially through the education of their children. Many such stories are covered in Stout et al.'s (2015) Community Profile, prepared for the neighborhood during the Westside Action Coalition (WAC) Project.

Churches play a key role for the social, political and spiritual well-being of African American community members. They are sometimes led by their founder or other strong leaders. Studies have shown that historically churches are first responders during disasters, and they do not limit themselves along racial or denominational lines, but on humanitarian bases, which they believe is in line with their faith. Writing about the role played by African American churches and their clergy, Trader-Leigh (2008) itemized the distinctive roles played by religious bodies, which include mobilization of resources, providing direct services to survivors, brokering relationships with the larger disaster response community, and acting as moral agents and social justice advocates.

Churches currently in the Westside include the Morning Star Baptist Church, Mount Zion Baptist Church, Temple of Christ, Church of God Militant, Trinity United Methodist Church, Christian Love Ministry, and African and Methodist Episcopal Church. These churches provide 
training, food, shelter, clothing, counseling, education, information, administer to spiritual needs, peacemaking, and other services to the neighborhood (Brooks, 2015), as cited in Stout et al. (2015).

However, Trader-Leigh (2008) noted that religious leaders have been left out from discussions about issues around community well-being and have, therefore, become lukewarm towards societal pressures and unprecedented changes that have come with it. In the aftermath of Hurricane Katrina in New Orleans in 2005, she wrote:

What stands out is how important the role of the African American minister has been, and how imperative it is for ministers to be seated at the disaster preparedness planning table. Black churches have been largely overlooked in public policy disaster management circles, even though they have long served as crucial community-based partners, caregivers and service providers to the most vulnerable. (p. 2)

Trader-Leigh was talking specifically about the disaster relief efforts in the aftermath of Hurricane Katrina, but she was also alluding to the plight of African Americans and other minority communities across the country dealing with the decline and deterioration of their neighborhoods.

The lack of involvement of residents in the revitalization of their neighborhood by development agencies and other institutions also occurred in the Westside neighborhood, as indicated by personal communications. Community-initiated activities that used to engage stakeholders, especially churches and ministers, are no longer practiced. Perhaps this suggests that there was no strong bond or shared aspirations and strategies among African American churches as has been generally believed. If McMickle's (2002) account of the concept of "The Black Church" has any validity, it means that black communities have work to do to unite for a common 
cause. He debunks the fact that the African churches and ministers were united and sought the common good collectively. In his words, this was:

... not true, and there were numerous differences found among Black communities which were reflected within their community churches. Black communities differed from region to region. They were divided along social lines, composed of persons from different economic levels and maintained varying political philosophies. Black communities in the inner cities of the United States have traditionally differed from those in rural areas, etc. (p. 8)

It may be too early to conclude that this has been and perhaps still is the case in Westside, but informal conversations have so far indicated that churches' community involvement has been declining since the 1960s. There is a visible disconnect from the foundation of what used to be the acceptable culture and norms of the neighborhood, and everyone now operates the popular biblical verse, "To thy tent O Israel!" 1 Kings 12:16, or what Putnam (1996) described in Bowling Alone or better still, what Achebe (1958) described as "Things Fall Apart". The common theme that permeates these examples is that the bonds that once connected people in this community have deteriorated, and therefore make collaboration and collective effort difficult. The churches for example, used to put together programs of activities for residents to interact and share common concerns, today many of those activities are organized on a denominational basis with less participation and commitment.

\subsection{Dunbar School}

Dunbar School was built as a segregated school in 1928 with high quality building materials such as bricks, sandstone, and wood and was crowned with an asphalt roof. It opened for 
classes in 1929. The architectural style is known as Colonial Revival. It has a kitchen on the ground floor, and a gymnasium, classrooms and offices on the second and third floors respectively. Located at 103 High Street, Fairmont, WV, from the beginning Dunbar School's enrollment exceeded its capacity for the student body ranging from the elementary level through grade 12 .

The story of how the school came into existence is narrated by Charlotte Meade in the Community Profile by Stout et al. (2015):

In the 1860s, Black population began to increase in the area then called Middletown. That population came with differing skills, seeking work, housing, equality, a place to worship, a place to educate their children, and the opportunity to be in fellowship and community. In 1867, the Marion County Board of Education purchased a lot between Jefferson and Madison Street in Meredith Alley, later referred to as Dunbar Alley. The black community contributed time and labor in the construction of a four-room school building and later added a small wood-frame addition to accommodate the increasing enrollment. This building was referred to as "The Colored School" for 42 of its 61 years. (p.13)

The pioneer and only principal of the Dunbar School was the late William Oscar Armstrong. Armstrong was a native of Boston, Massachusetts and a graduate of West Virginia State College in Institute, WV, now West Virginia State University. He was interested in teaching and mentoring African American children. This was why he decided to accept the job in the capacity of acting teaching principal and later became full principal. There is no question as to how effective he was at this position because he was all out there working with Blacks and Whites, kids and parents, teaching and mentoring, advocating, and making peace all at the same time (E. Dobbs, personal communication, December 9, 2017). 
To understand the history, social context and political dynamics in the Westside neighborhood, it is important to include a key actor like Armstrong who was at the center of many activities in the community. This study therefore includes an analysis of historic manuscripts, found at the West Virginia Historical Library, credited to Armstrong. A section is set aside in the methodology chapter to discuss the thoughts, ideas, plans and accomplishments of W.O. Armstrong in the Westside neighborhood.

Dunbar School was to the Westside neighborhood what Siddle-Walker (1993) describes as one of the "unidentified good community schools" (p. 163). Dunbar School and others like it were not well known because educators and researchers tended to focus on urban high schools, not small-city minority schools. This lack of recognition left authorities unaware of the value that local schools were adding to their communities. Dunbar was a model school with remarkable successes in academics, sports, drama, music and poetry that enjoyed the support from members of the community. In fact, the school's strong performances in sporting activities saw the basketball team undefeated in the 1918/19 season. Its students became winners of the State's One-Act-Play contest in 1935 and 1936 with the plays titled "The Whirl Wind" and "Dregs" respectively. In addition, Dunbar School narrow lost 6-7 to all-White Fairmont Senior High School in the penultimate football game before desegregation in 1954.

Dunbar School was the center of the Westside community for socialization, communication, relationship building, and an education center of the neighborhood. Per residents, it didn't matter if you had a child attending, it was a place for everyone. In other words, the facilitation of community relations as well as other social capitals in the neighborhood were tied to the school. Wilkinson (1991) described the distinctive role played by Dunbar School in terms of strong and weak ties. While strong ties are intimate and ongoing interactions among family 
members and close friends, weak ties refer to more transitory relationships and fewer interactions among individuals (Granovetter, 1973). Both authors believe that these ties are essential to the maintenance of community stability and residents' social well-being.

Finally, in compliance with federal regulation on desegregation, popularly known as Brown v. Board of Education, Dunbar School, like many other schools in African American communities, was closed in 1955. This disrupted and displaced students, teachers, administrators, and impacted housing, employment, and other aspect of community life. As summarized by Stack (2015):

The struggle for equality of opportunity in West Virginia was not perfect and not without negative consequences. The closing of local African American schools resulted in a loss of community identity in many black communities. Some black teachers lost their jobs and others were placed in predominantly white schools. (p. 47)

Dunbar High School was closed after Fairmont schools were integrated in 1955 and reopened as Fairmont Junior High School Annex in 1963. After petitions from Westside residents it became Dunbar Elementary School in 1971, which also restored its original name. Dunbar was finally closed for good in 2007. By 2008, a group of alumni started a foundation that obtained ownership of the building (Stout, 2015). However, raising enough funds to renovate the building so far been unsuccessful. 
Figure 8. Frontal View of Dunbar School.

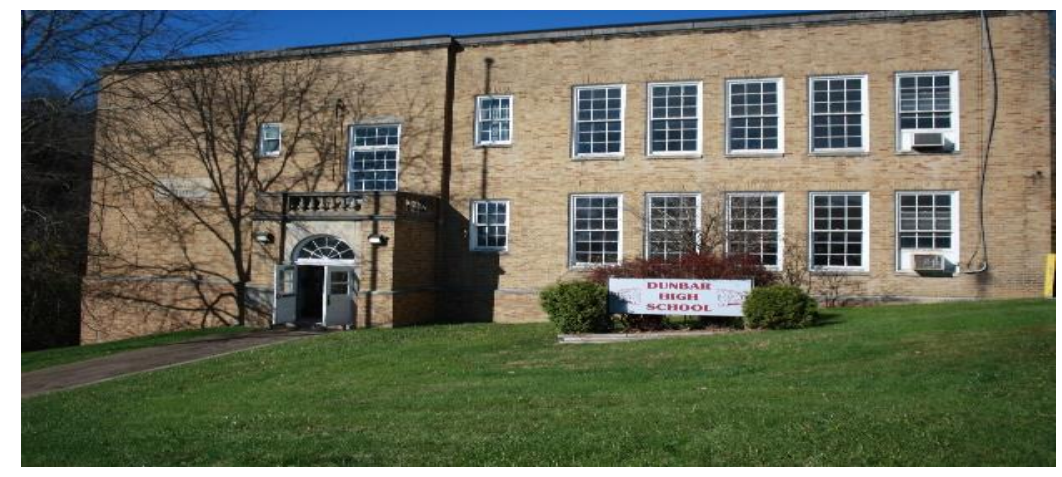

Figure 9. Dunbar School Basketball Team--Undefeated.

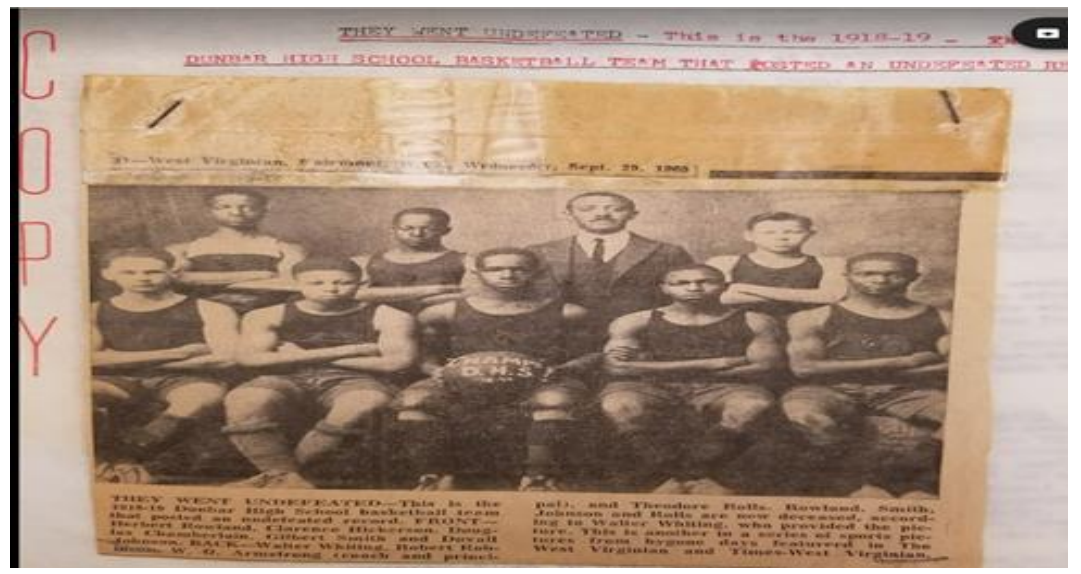

Courtesy: West Virginia Historical Library

Figure 10. Dunbar School Football Team of 1954.

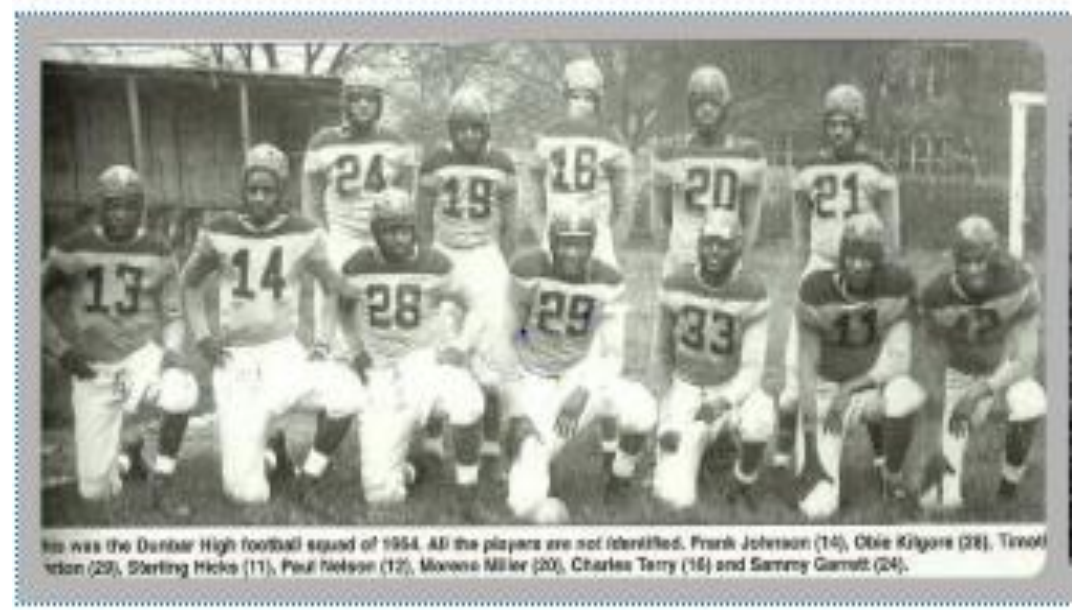

Courtesy D.D. Meighen 


\section{Chapter Three: Literature Review}

\subsection{Introduction}

Until the philosophy which holds one race superior and another inferior is finally and permanently discredited and abandoned, everywhere is war, and so war. Until the color of a man's skin is no more significant than the color of his eyes, and so war. And until the basic human right are equally guaranteed to all without regard to race. And until that day, the dream of a lasting peace, and world citizenship, the rule of international morality, will remain but a fleeting illusion to be pursued and never attained. Now everywhere is war...

(Bob Marley and the Wailers, 1976)

The literature for this study is drawn from a broad and diverse spectrum. It touches on issues and policies in community development, and how they filter down to the local communities and vice-versa. The literature is interdisciplinary and cuts across a range of issues and offers opportunities for connecting diverse ideas and issues. This review is both historical and critical. It is historical because it follows events in the Westside neighborhood over time, and critical because the study asked pertinent questions on issues involving the lives and wellbeing of residents in relation to policies put in place to serve them.

It is natural to start the reviews with a quote that describes the community development profession as "a turbulent social field within which special-interest groups use the local stage to promote their separate, unrelated goals (Warren, 1978)." He did not mention who the victims of the consequences of actions of special interests were. Neighborhoods are fragmented by 
social and political actions that undermine their prosperity. As a result, many communities are underserved despite efforts of community development professionals.

Failures of community development may not be due to poor professional skills alone, but because special interests determine which projects are undertaken. Issues of politics and power are fundamental in community development. Machiavelli (1513) commenting on the reality of politics and policy in the $16^{\text {th }}$ century, wrote:

For the manner in which men live is so far removed from the way in which men ought to live, that he who leaves the common course for that which he ought to follow will find that it leads him to ruin rather than to safety. For a man who, in all respects, will carry out only his professions of good, will be apt to be ruined among so many that are evil. A prince therefore who desires to maintain himself must learn not always to be good... (p.364).

Do we then have to wonder why sustainable success in community revitalization is considered utopian? The claim that there is no invisible force controlling how the profession is run, depends on who you're talking to. The point is that until authorities work with communities and community development practitioners to review some of the policies that make difficult the process of community revitalization, it will continue to be a "Herculean task" for all the parties involved.

This literature review is influenced by the National Civic Index (NCI) (Kubisch et al., 2012; Hodgett and Deneulin, 2009) and particularly by the perception of how a community should be developed. The NCI is a "creation of the Board of Directors and Staff of the National Civic League and reflects their decades of experience in dealing with the issues of community 
well-being and citizen self-government" Gates, (1987 p.472). We also draw from a wide variety of literature including books, articles, plays, websites, and movies. Issues covered include history, race, segregation, desegregation, power, policies, community, communication, and development. One objective of the review is to see how the thoughts and ideas of scholars like Machiavelli, Horkheimer, Adorno, Freire, and Fanon and recent others influence and shape the community development profession, especially its impact at the community level.

\subsection{A Concise History of Community Development}

The history of community development is specific to different peoples and cultures. Depending on where you are from, your environment always rubs on your perception of what constitutes the history and meaning of community development. Community development came about as a reaction to impoverished communities and people (Mayo, 1975). Impoverished communities have been part of societies for a long time (Midgley et al., 1986). Deliberating on the problems that led society to community development, Sheen narrates;

Global poverty did not just happen. It began with military conquest, slavery and colonization that resulted in the seizure of land, minerals and forced labor. Today, the problem persists because of unfair debt, trade and tax policies. In other words, wealthy countries taking advantage of poor, developing countries. (The End of Poverty? [Documentary], Sheen (2015)

Across cultures, neighborhoods and communities have ways of adapting and helping one another in times of needs and emergencies. In traditional Nigerian society, for example, community members were supportive of members who were going through rough times, especially mourning of their loved ones, during which times they were forbidden to farm, trade 
or go about daily activities. The Bette people of Northern Cross River State of Nigeria are proud warriors who view gestures of help in form of material or food items from others as a sign of weakness, devised ways of helping others, without making them feel ashamed or embarrassed. They did this by helping with farm work, like clearing of bushes, tilling the soil, planting, weeding, harvesting and helping selling produce. These are age-old activities that are also practiced across many other communities and neighborhoods in Nigeria, although in recent times many such traditions have been changing.

In the United States, the concept of community development came into existence because of the ideas of reformers who sought to improve the lives of slum-dwellers, who were victims of industrial capitalism in the $19^{\text {th }}$ century. They were poorly paid and lacked basic necessities of life. Many of these poor were immigrants and racial minority wage workers. According to Hoffman (2012), the women who led many of the reform movements liked to call the totality of their efforts "municipal housekeeping." Others talked of dealing with "the social question," and historians later labeled it progressivism. Regardless of the terminology, what matters is what the movement does to influence the lives of the people for the better.

Prior to the manifestation of the effects of industrialization, however, community development in rural American societies had its roots in organized, purposeful, self-help activities (Phifer, 1990). Over time this metamorphosed into the formation of different organizations and movements dedicated to improving the lives of rural people after the Civil War (Fritz, 1989). They included President Theodore Roosevelt's Country Life Commission and the Smith-Lever Act of 1914, which established Cooperative Extension Services. Phifer (1989) observes that, although the history of community development is anchored in self-help 
and self-reliance, community development as a deliberate and calculated effort to improve communities through democratic participation did not take off until the $19^{\text {th }}$ century.

Unfortunately, as Hoffman (2012) notes, while reformers were trying to help the people, they left behind the impression that outsiders would save the society by imposing reforms. The consequences of this is that reliance on outside assistance became the norm.

The Marshall Plan, although targeting whole countries rather than towns and neighborhoods, was an important event in the development of current community development practice and theory (Beckmann, 2012). Through this plan the United States contributed resources to helped rebuild devastated European countries after the Second World War. The lamentable state of Europe motivated President Truman to appeal to the United States' Congress who voted unanimously to approve aid to the affected nations. The Marshall Plan was a remarkable success (Ellwood, 2006). Devastated infrastructure, industries, and education systems across Europe were rebuilt, and Europe was back on the path to economic and social success (Kissinger, 2015). Consequently, the Marshall Plan became an inspiration for all community development approaches, regardless of social, economic, and political conditions.

What is often neglected in adopting this approach, are the processes used and the people and organizations involved. While the Marshall Plan could rely on the full power expertise of national governments, local government and volunteer organizations often lack access to all necessary expertise and suffer from tighter financial constraints. Another concern is that some public community development activities have become commercialized and politicized to serve special interests that often are not the targets most in need of assistance (Bunyan, 2012; Warren, 1978; Molotch, 1976). 


\subsection{Approaches in Community Development}

Community development employs a variety of approaches aimed towards revitalization of struggling communities. Community development draws professionals and scholars from sociology, economics, physical sciences, psychology, education and philosophy, international development, gender studies, human rights, public administration, international relations, development theory, economic development, peace and conflict studies, area studies and environmental studies. The inter- and multi-disciplinary nature of the profession reflects the nature of many community development projects and opens doors to diverse opinions and ideas, all seeking to improve the profession. We distinguish between traditional and contemporary approaches. This categorization, though coarse, fits the needs of our study.

Different approaches use different ways and methods to explain the concept. While the traditional approach is driven by power, influence, interest, hidden agenda, and manipulations (top-down), the contemporary approaches stress consultation, consensus, conversation, deliberation, motivation, and bottom-up participation. Bottom-up participation has been found to be more result-oriented and productive because of its focus on assets and people within a specific community and building from the inside-out.

The choice of method for community development work is ideally determined jointly by residents and practitioners, dependent upon the nature of the issues facing the community (Johnson, 2010). Regardless of the approach, best practice prioritizes people and their interests, and the development process should engagement them in decisions that affect them and their community (Barbaro, 2006). 
Traditional approaches include ideas and concepts from Diffusion of Innovation Principles, Modernization, Globalization, and Needs Assessment (Boone et al., 2002). These concepts reflect good intentions, but they are top-down approaches that fall short of current best practice as characterized in the preceding paragraph. A common characteristic is a unilateral approach and, even though they aim to have a universal appeal, they tend to be selfcentered and lacking enthusiasm for a participatory process. Most approaches, traditional as well as contemporary, are based on a neoclassical view of the economy, which is based on individualism and not communitarianism.

New approaches to community development were introduced in Europe and the United States in the 1950s and 1960s to improve the lives and living conditions of countries and communities in the developing world (Herath, 2008). Although well intended, they undermined the ability and integrity of the people for whom they were intended, by discrediting their values, cultures and heritages as well as the wherewithal to make choices for themselves (Ferguson, 1995). The many assumptions that characterized modernization ideology, left many worse off. Coetzee et al. (2007) believe that a particularly important weakness of modernization was its oversimplification of the nature of social change. Other weaknesses include the exclusion of the poor/residents as partners from participating in the process. Consequently, community members considered the movement as imposing strategies on them. The result was stagnation and in most cases retrogression (Reid, 1995). Writing on the role modernization played in Africa, Matunhu (2011) opined that:

Modernization impoverished Africa through colonialism and imperialism by the West and this trend is with us today as the East takes its turn to deplete the continent's resources such as oil and minerals. Africa needs to outgrow poverty 
and underdevelopment, but this may not be possible as long as we still believe in the power and strength of modernity at the expense of promoting new theories for Africa's development. Fighting Africa's poverty involves much more than a simple displacement of the traditional society by the modern society. (p.68)

Mainstream development thinking has its roots in the growth and modernization theories (Matunhu, 2011). This has continued to shape the pattern of how developmental initiatives by individuals, organizations and countries are designed and implemented. Because the Marshall Plan worked well in Europe, it was believed that similar plans could also bring underdeveloped countries out of poverty, and at the community level, help them to grow and be sustainable.

In addition to the Marshall Plan, there have been other initiatives as well. For example, Jimu (2016) suggested that large-scale injections of capital are the key to development. In contrast to this view, the "small is beautiful" movement (Schumacher \& McKibben, 2014) argues that human capital is the key to development. The green revolution was considered a technological fix for agricultural development (Farmer, 1986). Other ideas were the development of appropriate technologies, integrated rural development, and self-reliance. Some even suggested that developing economies would be better off by delinking them from the world economy (Rosero \& Erten, 2010).

Also, the emergence of globalization provided a boost to the development agenda (Tausch, 2010). Unfortunately, communities are feeling its effects in competition among individuals, groups and industries as well as services. The movement has created a widening gap between rich communities and the poorest communities. As a result, globalization has 
many critics, with some describing the movement as international capitalism, a force for oppression, exploitation and injustice (Crook, 2001). Others perceive the trend as a threat to local cultures, religions, and other groups, while international organizations benefit from it (Stiglitz, 2002).

Efforts to replicate and achieve uniform results in community development in different locations has created problems and failure. When residents don't see desired results, they become discouraged about development. UNDP (2003) also warned that traditional developmental approaches are usually dependent on a particular time frame, which does not always work in places different from those where they were used first.

In summary, while most issues raised here are international, it is important to understand how they relate to local problems that we are looking at. Ideas at the community level often have means of finding their ways onto the international stage and vice versa. In this study, we reference the Marshall Plan to illustrate that the role of government can be beneficial and decisive in development initiatives.

Contemporary (or alternative) differ from traditional approaches because of their focus on participation, collaboration, empowerment, sustainability, capacity building, and community-driven and asset-based development (Anglin, 2011; Chaskin, 2001; Kretzmann and McKnight, 1993; Nabatchi and Leighninger, 2015). The central idea of this strategy is to give power of ownership to residents, empowering them through the creation of conditions for their participation in the development process. In addition, it seeks to initiate the process from within rather than impose it from without the community; this is a major difference between the traditional and contemporary approaches. 
These alternative paradigms have a different undertone and approach, and are responsive to the social, economic, cultural, and political context of each application. We shall not spend much time to deliberate on all of them because there is a common thread running through all of them. For example, because participation can be interpreted in different ways, traditional approaches can claim to be participatory. The nature of participation often depends on who is leading the project; development specialists trained in the traditional approach are probably more likely to use a top-down approach than those with more background in participatory approaches (Arnstein, 1969).

Although the researcher used the asset-based community development (ABCD) model, he checked for a carryover effect from traditional models, as argued in the previous paragraph. If we ask people to look for deficits in their communities, they will usually find them; if we ask them to look for successes, they also will usually find them. In both cases, and their views of their community will be colored by the question or request (Kral, 1989). We should, therefore, ask questions that do not skew the answers.

The ABCD model is more participatory than other approaches, but its implementation depends on the community and how community agents frame the project and interpret process outcomes. As articulated by Kretzmann (2010), the ABCD model relies on pillars such as assets, strengths, passion, and skills present in a community and not needs. The concentration on assets is what distinguishes the ABCD from traditional models. It is community-driven and bottom up (Kretzmann, and McKnight, 1993), and community stake holders have a voice in the development process. They work in partnership with development agents to achieve the community's goals; professional experts work alongside residents. ABCD works by stepping back and giving charge to residents (Bergdall, 2012). This was the model used in the Westside 
Action Coalition Project, also known as Fostering Fairmont Project, where I was a part of and eventually became a precursor to the dissertation study. Its success depended on how the project was conceived, the framing of the issues, planning and implementation, and the manner in which residents were involved, and the timing of specific actions also had an effect. Once the project was completed, perceptions of residents of project's success differed, with many expressing reservations. The reservations and the reasons for them form a part of this study.

The ABCD model attracts different criticism from one community of application to another. The most important lesson learned from residents' feedback is that the model implementation is specific and unique to each community. Identification of community-based skills, culture, knowledge, resources and processes (Ife, 2013), planning, development, implementation and evaluation depend on what is available in the community. We should not transfer or replicate ideas from other locations without the input and consent of residents.

\subsection{Arthurdale School}

Arthurdale School in Preston County, West Virginia, is a community development experiment implemented during the Great Depression. It was the first federal subsistence project and was developed to provide land to unemployed coal miners. Framed under the canopy of Progressive Education, the central idea was to demonstrate how poverty could be relieved. The project included the establishment of a school that served the needs of economically disadvantaged people in the area and was community oriented. Perlstein and Stack (1999) describe the Arthurdale School as a system of community-centered schooling that organized the curriculum and activities around the needs and desires of the poor, adding that the school did not just promote the development of the individual but also played an important role in the revitalization and transformation of community life. 
The project was initiated by President Franklin Delano Roosevelt on the suggestion of his wife Eleanor, to help communities that were traumatized and distressed because of the Great Depression. The idea was to help communities and their people out of abject poverty and prevent them from moving to the cities but the other way around. This generated support from renowned individuals and scholars alike. The philosopher John Dewey, for example, was a supporter of the initiative who visited Arthurdale and, for a while, organized 150 visitors every week. In Dewey's views, Arthurdale held extraordinary significance for education (Stack, 2015). Other prominent figures that were tapped by Eleanor Roosevelt, to see to the success of the project included Bernard Baruch, who was a financier who advised and underwrote Arthurdale's educational programs. Other visitors and supporters were Lucy Sprague Mitchell, a pioneer in education and advocate for women, and Carson Ryan, who was the president of the Progressive Education Association which was founded in 1919 and lasted until 1955. Elsie Clapp, an accomplished progressive educator whose mentor was John Dewey, was tapped to coordinate and run Arthurdale School based on her excellent credentials.

Arthurdale as conceived did not last very long because it was riddled with problems that mitigated its success. As Stack (2015) notes, one of these problems was the failure to focus on conditions faced by homesteaders. Instead, Arthurdale's leaders were more concerned about hope for new social economic lives for the people, without actually empowering them. Another important way in which Arthurdale failed, was the exclusion of African Americans from this socio-economic experiment. This was contrary to the initial perception of Dewey and Clapp, who had envisioned an inclusive community, with their collective view that "a community could not exist in a climate of alienation and distrust" (p. 230). 
Blacks were among minorities that were excluded from Arthurdale School. Some of the reasons given for their exclusion were that they were from the South and not natives of West Virginia, who could not survive the cold (Stack, 2015). The decision was made in Washington and Whites were looking at Blacks with hostilities (Stack, 2015). These flimsy excuses persuaded W.E.B. Du Bois to advocate for separate cooperatives for African Americans. He felt that this would afford the Black race the opportunity to develop and grow their own identity. In Du Bois' view at the time, as cited by Perlstein and Stack (1999):

... If Blacks were allowed to live in Arthurdale, they would be excluded from homestead schools, as well as from economic opportunities and political participation. Instead, they argued for Black consumer cooperatives, schools and other institutions that enhanced African American political and economic power and fostered a distinctive and vibrant Black Culture (p. 231).

Arthurdale is considered important for this study because of the issues of class, race, segregation, and injustice explored. They are similar to the issues that have been present in the Westside neighborhood. Arthurdale is located north of Fairmont, West Virginia, about 40 minutes by car.

Racial and discriminatory issues were present in Arthurdale School but was never talked about. It is important to mention that Arthurdale was nationally regarded outsider White teachers and Western European English-speaking coal mining families who were very poor. Making references to the biography of Clapp (the principal, a Dewey protégé), a White woman from Columbia Teachers College in New York City in the 1930s Depression Era, Stack noted that, Clapp never mentioned anything that had to do with race and class throughout the life and time at Arthurdale School, even though the problems they posed to the success of the 
homestead school were apparent early on. Silence about burning issues tended to create animosity and enables injustices against other people. Dewey, however, attributed the failure of the Arthurdale School to individualism and capitalism, stressing that they were also the reason why other democratic institutions struggle altogether.

Another example of community development that included issues of race and economic status occurred in the aftermath of Hurricane Katrina in New Orleans and many residents lost all their possessions. The government decided to have its school become a model of privatization for school districts. According to Buras (2014), this was instigated by a substantial number of White groups who were bent on displacing African Americans, so that they could build a "new" New Orleans. The city closed public schools and fired 7,500 black veteran teachers and replaced them with White teachers and at the time converted public schools into charter schools, that compounded the problems of African American people. Buras captured the situation in this way: "The entrepreneurs grow fat while families and children lose schools that once were the heart of their community" (Buras, 2014).

The feelings and experiences of students in Westside who were moved to other schools when the Dunbar School was closed in 1955 have parallels to students' experiences in New Orleans. The community lost an important hub and desegregation of public schools also took away professional opportunities from teachers and leadership opportunities from African American students. As a Westside resident asked during one of our community meetings, “Why was the school closed when discrimination was unfettered?" I didn't know what to say but I thought to myself that, "so perhaps that the children will not know which door to enter or exit through, so that unfettered discrimination will have a field day." 
However, we must say that many of the perceptions expressed by residents during informal communication and pilot study have not been verified. This is what has happened locally and nationally, yet in this study we wish to find out more about what happened specifically at Westside because we don't really know the details but the elderly community members who were there may have some insight.

The inclusion of Arthurdale and New Orleans in the aftermath of Hurricane Katrina in this literature review is to show how the community development process can be hampered by the activities of government and other agents. There is likelihood of Prejudicial governmental influences that discriminate against Blacks may persist without awareness of bias, dialogue, and policies unless there are deliberate conversations to recognize prejudices and remove them from shaping policies and programs.

\subsection{Education and African American Communities}

Education is a priority to any society and people. A community that fails to provide basic education for its children is doomed. The historical account of Black migrants from the South who came to reside in the Westside neighborhood, has it that providing an education for their children was one of their topmost motivations for moving. This motivation aligns with Mandela's (1991) description of "education as the most powerful weapon which can be used to change the world". In a 1997 speech, Mandela articulated that:

The power of education extends beyond the development of skills we need for economic success. It can contribute to nation-building and reconciliation. Our previous system emphasized the physical and other differences of South Africans with devastating effects. We are steadily but surely introducing 
education that enables our children to exploit their similarities and common goals, while appreciating the strength in their diversity (Mandela, 1997).

Whatever their motivations, the migrants had a perfect understanding of the values of education and were prepared to pay a high cost to give it to their children. If there is anything that best describes a Black family, it is the attention and care they give to their children. As Hill (2001) noted, children are the very core of the African American family. Black families, through a unique dual-socialization process, attempt to pass on to them a combination of African American and African-based values. This also explains why Nobles (1985) posits that the African American family exists for the growth and development of children, rather than for the self-actualization of adult members of the unit. What makes this group function is their ability and resilience to work together as a team in the face of adversity and fighting for common goals.

People and authorities may not understand or agree with the quality and values that African Americans attach to the education of their young, but the unique dual-socialization process has made them who they are and the kind of future they envision for their children. Walker (2000) describes the success of Black schools vis-à-vis the education of Blacks in other schools to be tied to the work of "exemplary teachers, the curriculum and extracurricular activities, parental involvement, and the leadership of school principals" (p. 162). The collective responsibility of educating children is conspicuously missing in integrated schools. This is due mainly to the way the system puts the responsibilities for learning on the teachers and administrators. This approach deprives Black children of a form of education that has been successful for them. 
Black communities see education as a collective endeavor, and this accounted for the success of many Black schools in the face of unequal facilities, transportation, and overcrowding prior to integration (Walker, 2000). Many efforts made by schools in collaboration with parents and other members of the community to help African American children succeed went unnoticed by scholars and authorities alike, but Walker (2000) and Nembhard (2015) contend that this was an attempt to monitor, dismantle and take control of the educational structures of the Black community. These two authors see similarities between what happened to African American children and the education and enculturation of Native American children.

Berger and Fisher (2013) highlight education in their research on community economic development. They identify education as a foundation for economic success, shared prosperity, and investment in strategies that make people more productive. Therefore, providing expanded access to quality education and related support—particularly for young people who currently lack such access-will expand their economic opportunities, while also strengthening the overall economy.

Education is a fundamental building block for human development and for reducing poverty, improving health, gender equality, and even peace and stability (Mandela, 1991). Because of education's importance, it attracts the attention of many actors in society, including politicians. The politicization of the education of Blacks dealt a blow to the structures that were built primarily for the education of their children. Osokoya (1987) argues that education is a method by which society inducts its young ones into full membership. So, for a community to grow and be even with others around it, it must, as a matter of necessity, establish an educational structure that perpetuates its culture and values. 
Politicization of education is not limited to African American communities. Illich (1970) categorized learning forms into dominant and convivial. The dominant, also referred to as institutionalized form of education is forceful and places restrictions on learning, but the convivial or deinstitutionalized form on the other hand is without the restrictions imposed on learning by the former. Illich proposes an "autonomous and creative intercourse among persons, and the intercourse of persons with their environment; and this in contrast with the conditioned response of persons to the demands made upon them by others, and by a manmade environment."

The closing of Dunbar School may have reduced the interest in, and opportunities for, residents in community activities. With children as the center, people were willing to sacrifice for education and their well-being (Meade, 2017 Informal Communication). The separation brought about by desegregation made the involvement of the Black community in the education of their children more difficult. Their previous commitment to work with teachers and principals, who were also mentors to the children, have become more difficult, and many community members have therefore withdrawn from involvement in their children's education.

Politics in education are old and not limited to African American communities. Illich (1970), Spring, (1998), and Sidorkin (2009) at different times have pondered issues and interests that have entangled the educational system and caused it to deviate from the original purpose of learning for all. Illich advocated for a rebuilding of education systems that provides opportunities for learning outside of the school community (he called this 'deschooling'). In his words, what the community needs "are new networks, readily available to the public and designed to spread equal opportunity for learning and teaching” (p. 24). 


\subsection{Housing and African American Communities}

Communities do not exist in a vacuum. What constitutes a community is usually determined by physical, organizational, and social structures within a geographical area. Housing is particularly critical among the physical assets; there is no community without housing. Housing has been associated with wellbeing, healing, recuperation and happiness of people (Tunstall, 2012; Krieger \& Higgins, 2002).

At the national level, the U.S. Department of Housing and Urban Development (HUD) is charged with responsibility for housing policies. Its mission is

... to create strong, sustainable, inclusive communities and quality affordable homes for all. HUD works to strengthen the housing market to bolster the economy and protect consumers, meet the need for quality affordable rental homes, utilize housing as a platform for improving quality of life, build inclusive and sustainable communities free from discrimination, and transform the way HUD does business. (U.S. Department of Housing and Urban Development, 2017)

HUD's mission statement stresses inclusiveness and overall impact, regardless of color or locality. As is the case with many government agencies, the problem does not lie with policies alone, but their implementation. Thus, HUD has been at the center of criticisms ranging from bad policies to discrimination against minority communities. African American communities, in particular, have been poorly treated in the areas of allocation of funds, rent, lease, finance and access (Massey, 2015). This was legal after the abolition of slavery. This 
injustice was corrected with the passage of the Fair Housing Act of 1968, yet positive change has been slow (Yinger, 1997; Conrad, 2005).

Gross (2017), in an interview with NPR opines that marginalization or segregation in housing did not happen in a vacuum but was a deliberate federal policy with the explicit intent to segregate communities:

The Public Works Administration program and housing was primarily designed to provide housing to white middle-class/lower-middle class families. The progressive aspect of it was that some projects were built for African Americans as well. But it was explicitly segregated. And in many cases, it segregated neighborhoods that had never known segregation before. So, this went on throughout the country.

A recent study by Hanks, Solomon, and Weller (2018) shows a large gap in wealth distribution between Whites and Blacks in the United States. With systematic discrimination, it was difficult for Blacks to build wealth as well as Whites. The reason for the disparity is due in part to long historical discrimination against Blacks. As stated by the authors:

...A well-documented history of mortgage market discrimination means that blacks are significantly less likely to be homeowners than whites, which means they have less access to the savings and tax benefits that come with owning a home. Persistent labor market discrimination and segregation also force blacks into fewer and less advantageous employment opportunities than their white counterparts. Thus, African Americans have less access to stable jobs, good wages, and retirement benefits at work all key drivers by which 
American families gain access to savings. Moreover, under the current tax code, families with higher incomes receive increased tax incentives associated with both housing and retirement savings. Because African Americans tend to have lower incomes, they inevitably receive fewer tax benefits-even if they are homeowners or have retirement savings accounts. The bottom line is that persistent housing and labor market discrimination and segregation worsen the damaging cycle of wealth inequality. (p. 1)

The Westside neighborhood is experiencing effects of past discrimination. Of the 300 dilapidated and abandoned housing properties identified in Fairmont in 2014, most are in Westside. This is causing a variety of problems, including depressing property values and vacant properties attracting criminal activities. Some reasons for why there are so many buildings in poor condition include absentee owners and heirs who lack the means to maintain them. Other obstacles are lack of qualifications, access by residents to some government loans or grants, and the inability to come up with required matching funds.

\subsection{Community and the Church}

Churches and schools have been indispensable in building the Westside community and it is, therefore, appropriate to consider their activities over time. Insights from their successes and failures also help understand the community's present conditions and trends, and prospects for development. In many communities, religious groups have found ways to support and help residents overcome difficult situations. Churches and communities are frequent partners in developing a viable community. Churches have played particularly prominent roles in the formation and supervision of youth programs, rehabilitation of ex- 
convicts, and support for seniors, lunch program for kids, and after school activities (Soaries, 2010).

Churches in Black communities have played important social, educational, and cultural roles in developing, nurturing and sustaining community value systems.

In a segregated society, church was the place where people fulfilled their human potential, developed their God-given talents, made corporate decisions, voted for their officers, owned property, created benevolent societies, raised money for schools and scholarships, celebrated their marriages, blessed their babies, mourned their loved ones' deaths and even learned how to read. (Soaries, 2010)

"Churches remain a pillar of hope and stability in African American communities. During a time of violence and hatred, the church gave more than just a religious safe haven; it gave them hope for a brighter future" (McCullen, 2013). The fundamental role played by African American churches during the Civil Rights Movement in the United State is well documented. Moon (2013) wrote that church groups paid for fines, bail, and other needs of activists (p. 288). Many prominent leaders of the movement were members of church communities. Because of their history-making efforts, many churches in Alabama, Tennessee, Georgia and Oklahoma have become national landmarks (Moon, 2013).

The polarization of ideals, principles and concepts makes it more difficult to bring people together in pursuit of common goals. This problem is not unique to African American communities. Studies have shown that churches and civic organizations, in general, are going through a period of transition and transformation filled with challenges. Dreyer (2015) summarized the causes of these problems as articulated by Heitink (2007), Hauerwas (2013), Peterson (2013), Kung (1976), Oberholzer (1995), and Hirsch (2006). Growing secularization 
has caused declining church membership, reducing the influence of churches in shaping their communities.

Many scholars have contended that church should refocus on spiritual wellbeing, which churches have turned away from (Barth, 1933). This recommendation is supported by (Roozen, 2011) who coordinates a multi-denominational group survey on a decade of change in American congregations. This study affirms that there is a decrease in spiritual vitality, which is due to lack of commitment or emphasis on the need for it and other reasons. The overarching goal of Roozen's study was to show the state of health of churches in America. The tables below show some of his findings in the vital areas of challenges facing churches. Figure 12 shows congregations with conflicts in one or more areas of worship, finance, leadership or priorities in the last five years. Table 13 shows the significant impact of these conflicts on the spirituality of the church that results in low attendance and giving of fund to the church that help with meeting the needs of the church and community. Figure 14 on the other hand illustrates how the impacts of low spirituality has continued to hit the churches between 2005, 2008 and 2010.

Figure 11. Churches with High Level of Conflict.

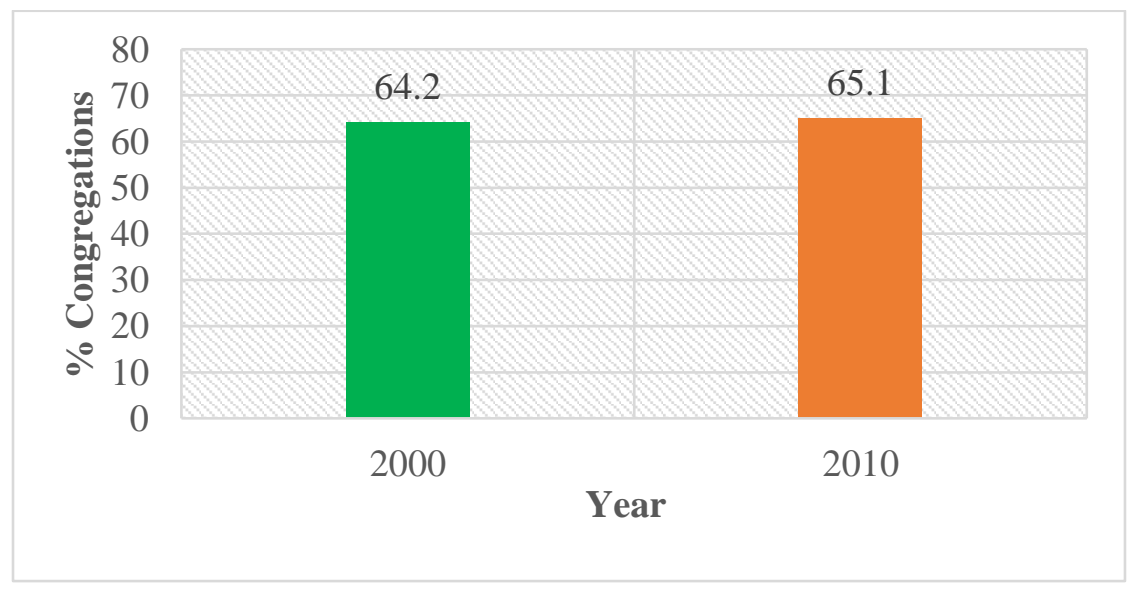

Source: Faith Communities Today 
Figure 12: Corrosive Effect of Conflict.

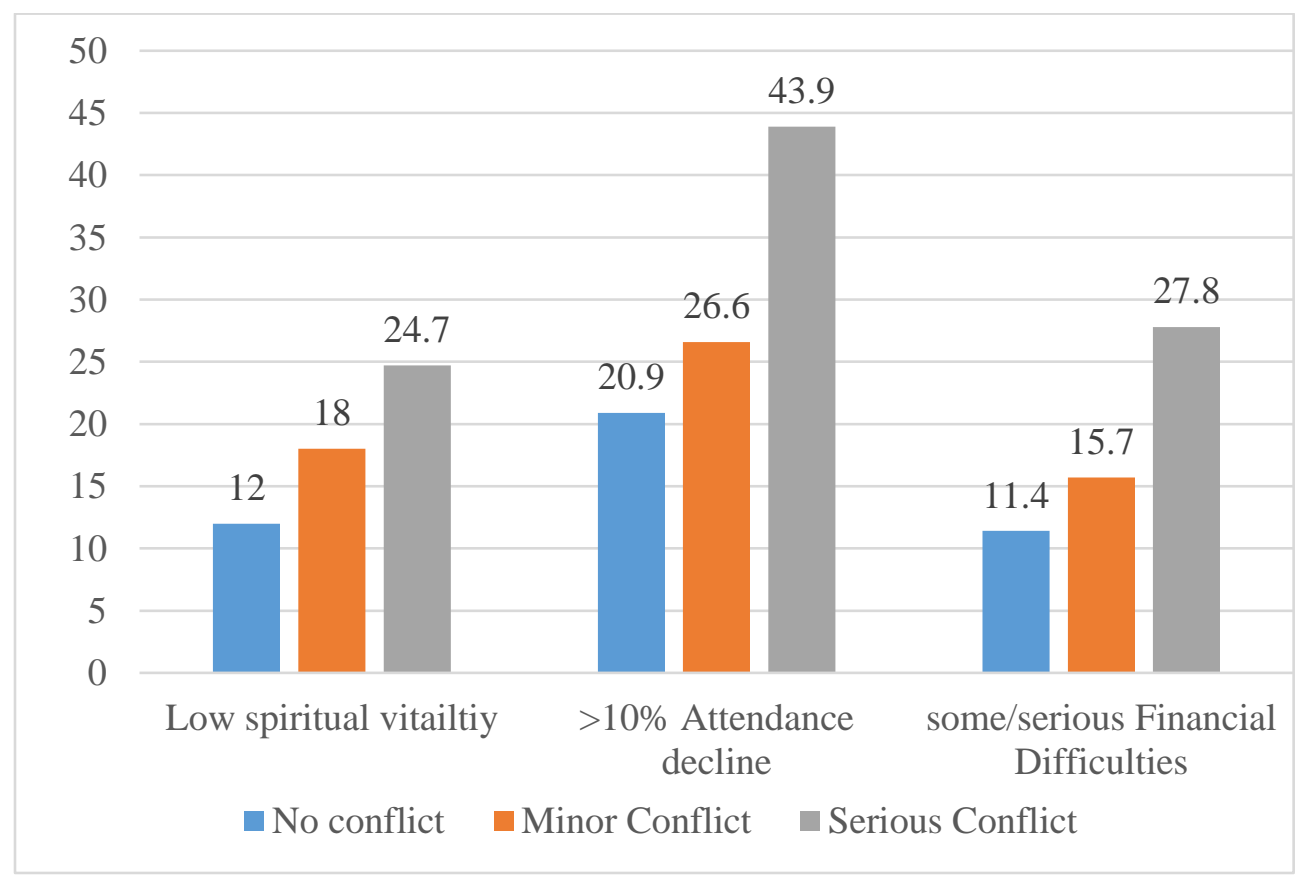

Source: Faith Communities Today

Figure 13: A Sharp Erosion of Spiritual Vitality.

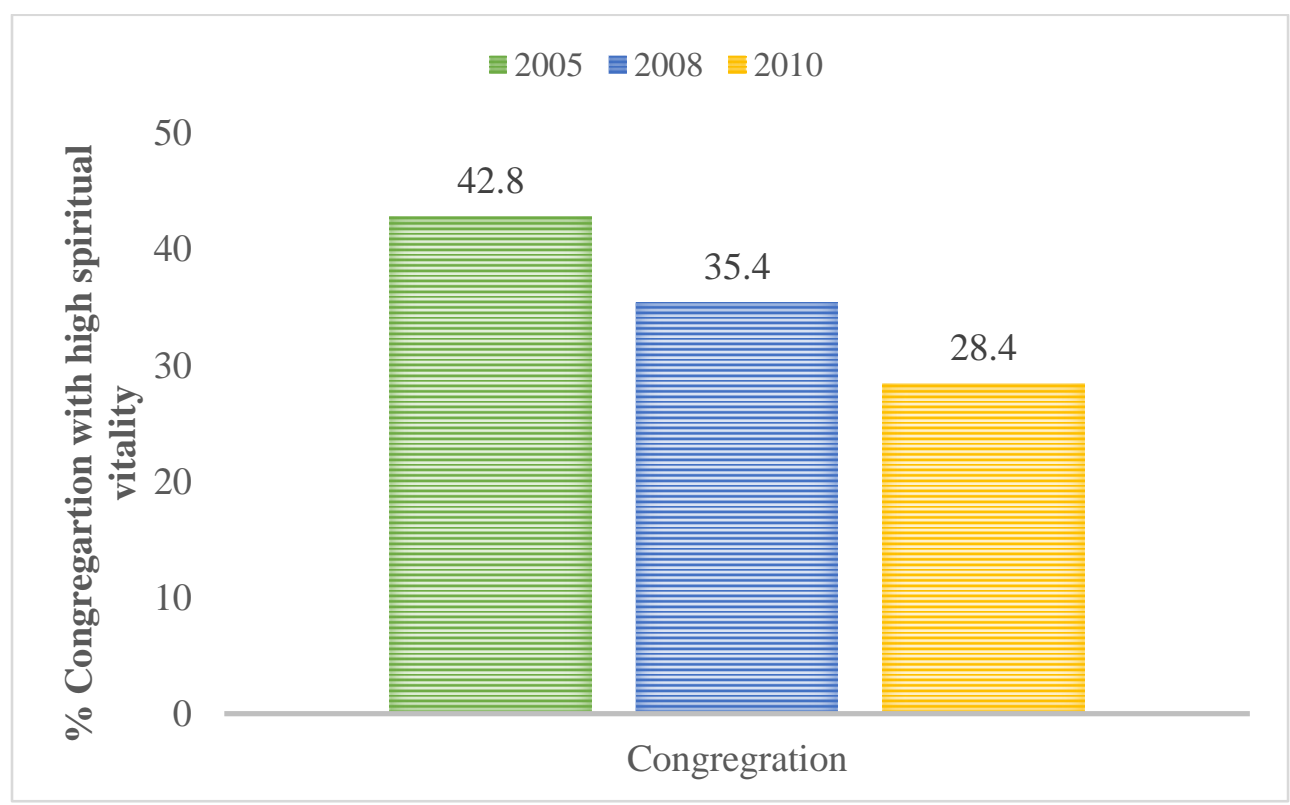

Source: Faith Communities Today 
With conflicts growing in and among churches over worship, finances, leadership and priorities, there is a spiritual implication that leads to decline in attendance, which ultimately affects the financial status of the church. It is important to mention that the same study was repeated in 2015 and not much change has happened, especially in the development of youths and young adults by a majority of congregations in America, though they are thriving and surviving (Roozen, 2015). One natural question from this would be for how long will congregations survive if youths and the young are left behind?

Although churches coordinated civil rights activities, there was no formal collective partnerships or sharing of knowledge or expertise between them. There were no long-term youth programs of activities to prepare the next generation of community leaders. In the Westside community, the absence of synergy and a common bond between church communities became a handicap when crises such as drugs, guns, killings arose (Julie, 2017 Informal Communications).

The focus here is on how this problem affects the Westside neighborhood. The issues facing churches are similar across the board, regardless of color or denomination. As the pilot study conducted for the dissertation suggest, the problems listed above have shifted the focus of the church from contributing to the development of the community to settling disputes and squabbles between church members and often members of neighboring churches as well.

\subsection{Community Leadership and Development}

Community development processes require leadership in the community, as a prerequisite for the success of programs and activities. It determines the present and future of the community through the mobilization of resources and citizen involvement. Leadership also 
facilitates the building of relationships between the people and development agencies. Kouzes and Posner (1987) note that, "When leadership is a relationship founded on trust and confidence, people take risks, make changes, and keep organizations and movements alive. Through that relationship, leaders turn their constituents into leaders themselves" (p. 19).

Maxwell (1999) describes the qualities of good community leaders to include solid character, charisma, commitment, communication, competence, courage, discernment, focus, generosity, initiative, listening, passion, positive attitude, problem solving, relationships, responsibility, security, self-discipline, servant-hood, teachability, forgiving and visionary. A good leader must be bold, have vision and skills to generate funds for community projects, obtain support for leadership decisions and policies, and promote program implementation (Langone, 1992). In many communities, while leaders lack some of these qualities, a leadership team may possess the whole range. Unfortunately, in most communities, forming an effective leadership team continues to be a challenge.

Historically, in African American communities, leadership figures are modelled after the philosophies of two prominent African American leaders, Booker T. Washington from the South and W.E.B. Du Bois - from the North. Washington was reserved and moderate (conservative) in his approach to leadership. He was satisfied to obtain industrial education for Black youths (Hynes, 2002) and rejected the mobilization leadership model, favoring instead social organization that focused on "nuts and bolts of outfitting a group with agencies, mechanisms, networks, and institutions related to modern social development" (Kilson, 2000, p. 298). Du Bois was the opposite; he believed in the mobilization model for which the main focus was the character of people, their citizenship rights, human rights and honor in a modern society (Kilson, 2000). 
Although the two leaders had conflicting leadership philosophies of how African American's challenges should be addressed, they helped create a lens through which issues were navigated and attended to. They both had an oversized impact on politics, the sciences and education. Impacts in education include many scholarships still in existence today. Their work paved the way for the Civil Rights Movement in the 1960s and inspired the formation of many associations, including the National Association of the Advancement of Colored People (NAACP), charged with the responsibility of developing and nurturing young African American leaders (Kimbrough, 1998).

Unfortunately, in some Black communities today, the role and functions of associations like NAACP are declining at a time when many believe they are most needed to keep up development and advancement with the rest of society (Wallop, 2018). Perhaps African American community leaders should realize that the development of their communities socially, economically, politically, etc., transcends their immediate communities and affects society at large.

An important principle of leadership is that leaders show up and use their keen sense of hearing, seeing and feeling in all situations that require the use of leadership skills. No community can afford to rest on its laurels, as the need to develop leadership on an ongoing basis is critical to developing sustainable communities. (Andrews, 2017)

Shrivers (2010) observes that potential African American community leaders are not motivated to come forward because they have been challenged, disappointed, or in the past have not received support from community members. Challenges facing young leaders include limited opportunities, conflicts regarding whose interests to promote, and scrutiny by White 
employers and constituents (Wenger, 2006). This deprives communities of leaders with the dedication and skills to bring about success.

This section concludes by referring to Freire's (1973) approach which involved problem posing (community work) and an each-one-reach-one approach to community adult literacy. It is not as a charismatic leader taking over to save a community, but a more democratic process that brings all residents and non-residents alike on board to solve community challenges. Failure to make important decisions often results in the loss of opportunities. Freire (1973) describes a "culture of silence," which is a system of dominant social relations that instills a negative, silenced and oppressed self-image among the powerless. Nevertheless, Freire insists, community members must speak up and act, or the change they desire will remain an illusion.

\subsection{Youth and Community Development}

Youths and young adults are a community's future. Therefore, caring for the youth is care for tomorrow (Cammorata, 2011). Unfortunately, many marginalized communities either lack the resources or neglect to integrate youths that have experienced marginalization (Ramsey et al., 2010). The decline of Westside's and Fairmont's economy is only one aspect of the challenge. As pilot a study indicated, the drug epidemic that swept the neighborhood stigmatized many promising youths and young adults and sent them to jail and prisons. After serving prison terms, there are no formal reintegration programs to welcome them back into society Thus, stigmatization continued, and Westside neighborhood youths have been disconnected from community life for a long time. Until the closing in 1955 of Dunbar School, conversations with residents show that life of the youths in Westside was tied to this school, which at the time had resources in the form of facilities, coaches in different sports, 
entertainments, and other skill development activities. Teachers and mentors were available to assist and guide youths. Churches also provided guidance and support. The impression from conversations is that the mentoring and general support provided by Dunbar School has not been replaced by the schools attended by the neighborhood's children now.

The Fairmont Youth Development Center (FYCDC) has been the only entity located in Westside that has been trying to provide support in the form of after school programs and football coaching. In the face of acute resource shortages, the results are not tangible. The development, training and well-being of youths should be a collective effort that includes different stakeholders inside and outside of the community (Delgado, 2002). Unfortunately, per pilot study, this kind of support has not been forthcoming.

\subsection{Resident-centered Community Building}

In this section the researcher argues that community residents should be at the center of development initiatives. They should be supported to generate development and works, plans, and evaluate, and implement projects together. In other words, this approach encourages participation and collaboration between community development practitioners and residents. This is important because the knowledge and aspirations of residents should undergird the work and should inform decisions and the community's energy and commitment should drive the whole process (Kubisch et al., 2013).

Kubisch et al. (2013) introduce a community-oriented practical experience that includes a three-fold agenda: (1) share experiences, (2) learn from one another, and (3) celebrate each other's achievements. This builds a sense of community among participants and captures their collective wisdom. 
Relationship building is the foundation on which successful community development must rest. The strength of a community lies in the strength of the connections that people have with one another (Fisher \& Brown, 1988). If relationship issues are adequately handled, it makes the work easier and success may be assured. Community connections also matter because they reflect the history, experiences, conditions, capacities and potentials, many of which are unique to the community (Fisher \& Brown, 1988).

The capability approach as presented by Hodgett and Deneulli (2009) targets a community-building strategy that is oriented towards the functionality of a community. It is based on the notion that the well-being of people is not effectively determined by what they consume but by what they are or do, such as being healthy, their ability to read or write, and taking part in activities in the community, which is determined also by the freedom to do so. Citing Sen (1993), the authors define capability as a person's ability to do valuable acts or reach valuable states of being. Many different factors determine the capability of communities, but it may take time to figure out which factors matter most in a community. Many communities do not meet the requirements of the capability approach as defined by Sen.

Kubisch and Deneulli (2013) suggest that to have accurate measurement and understanding of people's situation and their capabilities for community revitalization, there is a need to include their unique stories; their narratives should form the core of policy decisions. According to them:

... in order for the capability approach to make a significant contribution to policy research, we should explore the absolute presuppositions underpinning policy-making and recognize that there is no intelligible distinction between 
quantitative and qualitative research: both acquire meaning in terms of the social plot in which they are mobilized (p. 68).

To a large degree, policy decisions that involve community development are based on findings obtained from the analysis of quantitative data. Such an approach does not capture the views, experiences and stories of residents and often excludes the opinions of community residents. No matter how a policy is implemented, if it is based upon an incomplete or biased research premise, it is unlikely to benefit the community (Shafer, 2007; Crotty, 2012). Based on this premise, this study is about identifying issues in a marginalized community from residents' understanding, using an approach that captures their experiences while also advocating for the use of complementary quantitative and qualitative research.

In addition, it is through the complementary strength of qualitative approaches to research that data truly reflect the community and its people. Hodgett and Deneulli (2009) contend, therefore, that hermeneutics should be an essential complement to empiricism in policy evaluation, and that narratives should be the sine qua non companion of statistics within human development circles.

\subsection{Erosion of Community Values}

Destroying an individual's past destroys the foundation on which the future should be

built, and this alters the future that is possible. This explains why totalitarianism attempted to obliterate memory and replace remembered history by another newly created history (Riesman, 1950; Nisbet, 1962; Bellah et al., 1985; Miller, 1967). It reflects how historical events and actions have altered the well-being of communities and leaving them with unpredictable future. 
Erosion of community values tears down, destroys, or ignores the cultural heritage of one group, often in favor of a more dominant groups. Community heritage can be, monuments like religious buildings, museums, mundane structures, arts, schools, food, fashion, festivals, ceremonies, fashion etc. Because a community's identity is usually a reflection of what it is as a people, it is often a point of interest for attack by an enemy. The removal of Native Americans from their land and the subsequent abduction of their children to "Indian Schools" where they were punished if they spoke their native language and were taught nothing about their cultural heritage by their abductors also fits this description. Palmiste (2008) writes that Native American children were removed from their homes to learn White culture. Missionaries were also sent to convert native people to Christianity, with the primary aim of eliminating/eradicating the native cultures and believe systems (Sander, 2009). The motto was "Kill the Indian, Save the Man" (Yu, 2009).

The account of $\mathrm{Yu}$ (2009) also highlights the focus of the colonizers on forced assimilation using education as an alternative measure to relocation and extermination to subjugate the cultures of Native Americans. This was considered a better way to make the natives useful and productive in the new industrial life. Although early Native Indian students in the Euro-American school for Indians were consented by some Indian Chiefs, but it was under the camouflage that their land was taken from them because they were not educated. So, to stop that from happening, and to promote peace, they allowed their children to be taken to those schools where, according to $\mathrm{Yu}(2009)$

...the children at the Carlisle Indian school had extremely difficult times adjusting to their new living conditions. The health of many Indian students was in peril after European contact due to the lack of natural immunity. Food 
was scarce and of poor quality. Illness and death among the children were common. Many of the children suffered from separation anxiety, smallpox and tuberculosis which at that time quickly resulted in death because of the lack of medical treatment. While most of the children were sent back to their reservations, hundreds of others passed away at the school. A hundred and ninety-two children died and were buried in the school cemetery, a majority of whom were buried from the Apache tribe.

In African American communities, slavery, segregation and victimizations were used to suppress their cultural heritage. During segregation, however, African Americans were able to reenact their cultural heritage through the education of their children in folklore, music, family bonds, religion and resistance that characterized their ordeal during the slavery era (Mintz, 2007). However, scholars like Bell (2004) and Walker and Archung (2003), decried the effects of desegregation in leading to the closing of many schools in Black communities where these cultural values were taught. The fear of these authors is that African American cultural values are gradually going the way of Native American's ways of life, where students "found themselves an alien in both worlds after returning home to their reservations. They were too white for the Indians and too Indian for the whites" (Yu, 2009).

Although in many communities, people are living in close proximity, they often know little about each other and have no common goals (Markova, 1997). He argues that the manipulation of communities is not done without some internal involvement through actions serving external interests and the prevention of actions that would contribute to the progress of the community but run counter to external interests. Lack of agency does not only discourage community residents and signals to outsiders that the community does not control its own 
development. Maybe as a result of being powerless, many marginalized communities are looking for development support from the outside. An important question they should be asking is, who benefits from the current state of the community and how easily can those beneficiaries be displaced? Reliance on others denies residents responsibility and the power to make decisions and does not contribute to the development of a sense of community (Nisbet, 1962).

\subsection{School Closures}

Many schools serve as centers where a community comes together. Thus, in small communities a football or basketball game brings community members together to cheer and encourage their children. When a school closes, the community loses a social and cultural center. Students who attend schools outside the community make some of the most formative experiences elsewhere. Autti and Hyry-Beihammer (2014) affirm that school closings decrease opportunities for interactions among community members. Additionally, closed schools, if neglected, change from being community assets into eye sores and liabilities (Cohen, 2016). This is the case with Dunbar School.

Closure is described by Galletta and Ayala (2008) as the situation in which staff and students are transferred to new schools. School closures seem to be more prevalent in communities with a high percentage of poor and working-class students of color (Valencia, 2008). The story told by Westside residents is that the migrants from the South who came to settle at the Westside neighborhood specifically wanted a place where their children could get a good education. They made this a reality through the cooperation and sacrifice of time, money, and other resources. The school board only stepped in to assist, when the number of 
students kept increasing and the school was excelling academically as well as in sports and artistic performances (Stout et al., 2015).

School closures are common, but reasons for closures differ. They often are the result of consolidation to save costs. However, Cohen (2016) notes that many minorities believe that closures never save costs and view them as discriminatory based on a history of harmful experiments by governments on communities of color.

School closures are still occurring (Bryant, 2016), and not only in the United States. Egelund and Laustsen (2006) identified the reasons for school closures in Denmark to include quality of instruction, condition of school buildings, infrastructure, and counter-urbanization. In Finland, Autti Hyry-Beihammer (2014) stressed that school closures were an artifact of structural adjustments.

According to the literature, reasons for school closures by authorities differ and are often in the best interest of residents. However, many contributors question the criteria that inform the decision of which school to close. Residents are usually left out of the conversation, even though they and their communities are the ones to face the consequences. Given the central role of schools as community centers, residents and authorities should work together in determining the future of community schools; ethnicity and race should not be allowed to influence decisions.

School closures have consequences that affect the lives of community residents. It is for this reason that Egelund and Laustsen (2006), refer to school closures as a sign, rather than a cause of the death of rural communities. The authors emphasized the "sign" as an indication of worse things to come. Auti and Hyry-Beihammer's (2014) study of Finland revealed that 
the process of school closure included communications between officials and community residents, but sometimes participatory processes are used only to legitimize a decision that has already been made. They concluded that authorities often forget the pedagogical and social significance and possibilities of community schools.

In a related study, Kirshner and Pozzoboni (2011) report that students' process school closures the same way resident adults do. The results indicated that students, especially those from minorities, felt excluded from the decision-making process and did not accept the rationale on which those decisions were made. This result looks much like those from other communities across the nation, where people excluded out from a decision that affected their lives and that of their community.

The closure of the Dunbar School did not just shift or truncate the dreams of children who were learning at this high school, it also disintegrated community ties that brought people together. The foundation of education, mentorship, socialization, morals, values, hopes and faith that were supportive of the African American heritage was taken from them. This ran counter to the vision of Du Bois (1935) about the type of education that is representative of African American values. In his view, separate schools were needed because

...they are necessary for the proper education of the Negro race. The proper education of any people includes sympathetic touch between teacher and pupil; knowledge on the part of the teacher, not simply of the individual taught, but of his surroundings and background, and the history of his class and group; such contact between pupils, and between teacher and pupil, on the basis of perfect social equality, as will increase this sympathy and knowledge; facilities for education in equipment and housing, and the 
promotion of such extra-curricular activities as will tend to induct the child into life. (p. 328)

There is no doubt that Du Bois' ideal philosophy of education for African American people has been the current movement to re-invigorate All-Black boys' and girls' schools in many places in the US, using charters as a mechanism for doing so.

Dunbar School was the only African American school in the Westside neighborhood that was closed in 1955. When it was reopened as a desegregated Elementary School Annex it could not replace what was lost; it was closed for good in 2007. The policy, decisions, and process behind these transitions are not known to residents, but the struggles, deprivations, disintegration and other implications of those decisions are born by the residents (Buras, 2014).

The decision to close schools in African American communities, post-segregation era was not supported by Black scholars. They saw it as not suitable for the education of African American children and argued that the education in integrated schools will see children of color transition from the foundation of core principles and values of their communities, such as the commitment of the teachers and principal, and the support, encouragement, and standards that characterized schools' atmospheres (Walker, 1993). After desegregation, a common perception is that Black children are not receiving core educational values that are representative of African American values.

The African American community is less able to pass on its values to their children than before desegregation because decisions in integrated schools were dominated by White educators and administrators. Black educators, particularly in the early years, had very little influence. Parents and guardians found it more difficult to act as "co-teachers" and affect the 
education of their children (Walker, 1993). Westside community witnessed conversion of Miller Junior High School, the neighborhood's mixed elementary school was closed in 2008 and converted into a senior living center. It was eventually completed in 2015 . The foundation that acquired Dunbar School is still working to raise the funds to renovate the building, which is listed in the National Register of Historic Places. The Miller School is also included in the Register.

Some residents, during the pilot study, were disappointed with the conversion of Miller School to senior living center when the community is in desperate need of facilities and programs that could encourage and support the development of youth and young adults. Some argued and concluded that, perhaps those behind the project perceive the need to serve seniors was more urgent. They felt that the future of their community was being dictated to them by outside agencies with greater interest in seniors than the growth of the community's youth and young adults.

\subsection{Power Relations and Community Development}

We define power as the ability to control or influence the activities of others. Another name for power is authority; these two terms are often used interchangeably. Theodorson and Theodorson (1969) define power as the capability to control, manipulate, or influence the actions of others - with or without their cooperation - to carry out policies and reach desired outcomes.

Power in a community comes from residents who align themselves with like-minded people to pursue common interests and goals. Such common interests can cover a wide range area such as social, educational, economic, professional, race, ethnicity, political, gender, and 
religion. Presthus (1964) distinguishes between elite-led leadership and pluralist leadership structures. While the former refers to the highly educated, famous and accomplished, affluent, influential, elected and appointed leaders who often control resources, the later classification points to those who share ideas about common or popular goal and the well-being of all but often lack the means and resources to get what they want.

A further classification of power relations was introduced by Walton (1968). with pyramid, monopolistic, factional, coalitional and amorphous structures. The pyramid and monopolistic structures stand for a single form of leadership. A factional structure indicates more than one leader. Coalition suggests joint leadership based on overlapping interests. Finally, the amorphous structure has no particular leadership pattern. Leaders may emerge ad hoc when leadership is required.

Each structure represents a different sharing of power and control. Some participants may possess powers that they cannot share. This applies particularly to governments who cannot operate outside of legally determined processes and parameters. The choice of the leadership structure also depends on the nature of the project and the power of stakeholders. For example, a developer planning neighborhood development may not have to compromise with residents if the zoning allows for the development. However, if the development can only proceed after a zoning change or variations, then residents can affect the eventual outcome, even though they do not have the power to stop it, except by lobbying and pressuring city officials.

Gaventa (1981) describes power relations using a three-dimensional approach. In his view, power does not exist in the ability to win in politics alone, but also to determine what 
issues are being considered for action, and to influence people to understand and interpret issues in ways that serve their interests. In his words:

If the victories of $\mathrm{A}$ over $\mathrm{B}$ in the first dimension of power lead to nonchallenge of B due to the anticipation of the reactions of A, as in the seconddimensional case, then, over time, the calculated withdrawal by B may lead to an unconscious pattern of withdrawal, maintained not by fear of power of A but by a sense of powerlessness within B, regardless of A's condition. A sense of powerless may manifest itself as extensive fatalism, selfdeprecation, or undue apathy about one's situation... (p. 16).

From the pilot study, the issues discussed in this literature review so far are representative of relationships that exist between residents, their leaders and non-residents. Such relationships represent power relations, which ultimately regulate, control and determine how things are done in a community. To understand power relations in a community over time requires knowledge of its history and culture, which reside with residents and other individuals who have a relationship with the community.

To access the knowledge of how to navigate power relations in a community, it is important to understand the processes through which power relationships work. Walton (1970) identifies community power structures as reputational, factional, and decisional, and focuses on the characteristics of the community, current issues, activities in the community, and leaders present within the community.

As revealed by the pilot study, the issue of power relations in the Westside neighborhood are as old as the neighborhood itself. Power relations between community 
members, the institutions and organizations in the neighborhood, and up to the city officials, have not always been great. Informal conversations with residents blame a long period of neglect, lack of communication, and the perceived concentration of infrastructural development at the East Side at the expense of the Westside. This has resulted in distrust and withdrawal from community discussions and participation, in general. Within community organizations, churches are focused on their parishioners and not the interest of the whole community. Dunbar School, now known as Dunbar School Foundation, is less functional due to lack of funds to renovate the historical Dunbar School building into a community center to serve the needs of the community. Also, the Youth Center is starved of funds and support from members of the community. Residents express wariness with the attitude of the city towards their wellbeing and have therefore decided not to partake in community activities. The City, on the other hand, believes it is doing its best for the good of the neighborhood.

These scenarios conform to the descriptions of Gaventa (1981) that regardless of how the people who are affected by policies actually understand them, the powerful feel that they are doing nothing wrong. The consent of the powerless in reality often only reflects their withdrawal from participating in shaping public policy, but when they voice opposition, city officials sometimes give up in frustration over the perceived lack of appreciation of what they are trying to do.

\subsection{Summary}

The focus of this literature was on building community centered development. Communities with problems require strategies that bring about desired changes. Communities do not want experts proposing measures without consulting with the community. Professionals seeking to establish common ground with community members often find the process difficult. 
The difficulty sometimes stems from constraints imposed on governments and private organizations, which can be legal, financial, or political. In Machiavelli's words (quoted in the Poverty Incorporated documentary), “...the reason there will be no change is because those who stand to lose from change have all the power, and the people who stand to gain from change have none of the power."

To overcome problems encountered during community revitalization initiatives, we should adopt an approach that embraces residents" participation and "listens to their stories." Therefore, McKnight and Kretzmann pose the following questions: "What can community members do best for themselves and each other? What can community members do best if they receive support from organizations? What can organizations do best for communities that people cannot do for themselves?" (McKnight \& Kretzmann, 1993). These questions are the summation of the Asset-Based Community Development model on how to approach community development initiatives. 


\section{Chapter Four: Methodology}

This chapter presents the methodology for the study, which has the two major parts, data collection and data analysis. It reflects the critical theory perspective that chosen as most appropriate for this dissertation study and it articulates the researcher's reflections on the project.

\subsection{Reflections on Positionality}

Positionality is the side from where a researcher approaches the research. It is informed by the individual's social reality, with what s/he knows and how s/he came to know it, and assumptions about human nature and agency (Sikes, 2004). The worldviews that influence how and what we learn are influenced by affiliations, gender, disabilities, political allegiance, religion, status, class, and events (Wellington et al., 2005).

Denzin (1986) noted that interpretive research begins and ends with the biography and self of the researcher. Similarly, Sultana (2007) iterated that to undertake ethical research, researchers must pay attention to positionality and reflexivity. This author's positionality draws on experiences growing up, traveling, and especially from education. He experienced poverty growing up and the pains of separation and alienation from siblings, family and friends at an early age. The reflections on his experiences are relevant to this study, especially in the analysis of the experiences of residents because Westside neighborhood residents also have experienced deprivation, alienation, and degradation. With the related negative experiences of the researcher and study area's inhabitants, it is easier for him to filter interview responses and interpret the results of this research.

The author's environment and social conditions helped shape his ideas and opinions about social issues and life generally. As the first male child in a polygamous family in a patriarchal culture made his childhood difficult because his stepmothers saw in him a rival of their sons. His 
mother in her role as the first wife felt pressure from the community as well as her rivals. She also had to fend for her six children because her husband had become more concerned about his newer wives.

When the author was only four years old, his mother would wake him very early. She gave him a lantern so that I could lead the way to a neighboring compound where she used to grind the beans needed for frying bean cake, which community members used to buy on their way to the farm or that she sold on the market on market days. His mother and two older sisters carried the bowls of washed beans and followed him as he walked in front. Even though he was the youngest and could hardly defend himself in the event of danger, he was asked to lead because in the eyes of society he was the man. Local beliefs confirmed patriarchal relations; even evil spirits respected and would not harm men, regardless of their age.

Before he turned five, one early morning when his mother woke him, her tone was different from the usual. Expecting to be handed the lamp, instead she handed him two kobo, the rough equivalent of a cent in U.S. money. Almost whispering she said, "When it's completely dawn, take your sisters to your grandma and do not tell anyone where I've gone. I am going to my sister's place and then to Lagos from there. But I will come back to you. Remember that you are a man. Take care of your sisters.”

These were his mother's words as she slid open the make-shift door and disappeared into the early morning fog. He did not see her again until he was sixteen years old, but he remembered those words. Perhaps what fixed those words in his memory was the pain he suffered from his stepmothers and ordeals with his uncles' wives. His father's brother asked that he be brought to him when he heard about the harsh treatment from the stepmothers. Unfortunately, he passed away 
only a couple of months after the author's arrival when he was only six years old. He was then transferred to his father's younger brother.

The younger brother had married only recently. The author's responsibilities living with this young couple included many household chores, including fetching water, cooking, doing dishes, sweeping and hawking vegetables. This was preceded by routine work on the farms at different locations in the forest. On one hot afternoon on his way to the farm to bring home yams that were to be sold on the next market day, he was scared because a couple of days before, there was news about how a young school child was kidnapped and killed, and another story of how a young woman was kidnapped. The stories circulated throughout surrounding villages. This compounded his fears as he went about his daily errands, alone. Unlike other families with siblings, he was always alone. And so, it was a challenge for him to put the yams on his head. After many attempts of trying, he managed to get them on his head but lost the cushion cloth that was to provide some comfort from the weight of the yams. As he tore through the bushes on his way home, on the slope leading to the valley and the river, he heard a loud rattling noise very close to him. He started running down the hill with the yams on his head. He did not dare drop them for fear of punishment by his guardian. After a few steps the rattling noise was now in front of him and he saw two large snakes. He screamed and ran, slipping and falling and then passing out. When he regained consciousness, he found the sack of yams by his side and no trace of the snakes. He thought, perhaps they sniffed him and found out that he was "a man" and realized that they could not hurt him.

It was common knowledge in the community that the child who earned the most prizes in school (the author) was always alone and did not have books, pencils, slippers, a school uniform, and never wore Christmas clothes like other children. The only sources of food were koko-yam, 
water yam, cassava and bruised or tainted yams because the good ones, like the ones he was carrying, were for the market. Fruits and vegetables were everywhere because it was a farming plantation and they were mostly cheap and sometimes free.

Having experienced poverty and maltreatment, he understands what it is like to be poor and ostracized, and he can identify with people with similar experiences. What kept him going are the lessons he learned from it, including the words of his mother and the support of his teachers who understood his situation. Some of them used to invite him to their offices for a chat, and he used to shake his head and smile at questions about his family situation.

He had one of the highest scores in the Common Entrance Examination in Ondo State, Nigeria. His name was first on the list and this accomplishment paved the way for him to go to high school, although his guardians did not know how important this was. His cousin, Dele, may his soul rest in peace, schooled in the city and lived with Uncle Akawu, a young high school graduate, working with the Electric Power Company at the time. This cousin had secretly filled out his Common Entrance Application Form and selected his own school as the author's choice. Dele waited until after the names of admitted students had been released to tell Uncle Akawu, who went to the school to confirm the information. The uncle was surprised to see the author's name first on the list. The author successfully graduated from high school, acquired university education, and travelled across Nigeria looking for work and serving in the Nigerian Youth Service Corps.

The author does not feel as a member of a particular tribe or community because growing up and as a young adult he lived with different families and in a number of different communities and cultures. His late uncle and mentor, Akomaye Oko, used to tell people that he was a hybrid, in the way he relates to people and because his pronunciation of certain words in his native language reflected the places where he had lived. His uncle taught him to love and respect 
everyone, and to look beyond face value for the real worth of things. He also taught him to search for the truth and not to be too quick to judge or take sides.

As he continues his journey through life, he remembers his uncle and how he shaped who he is. He knows from his knowledge of agricultural sciences that hybrids are the offspring of two different animals or plants and possess qualities of both parents. The author is a strong, dependable and trusted heterosis (outbreed enhancement) of the many families, cultures, and traditions in his background.

The author has learned, socialized and mingled with Westside residents, as an outsider looking inward through observation and interaction with members of the community. Dwyer and Buckle (2009) argue that outsider-researchers, by not being members of the study population, may find it easier to acquire reliable knowledge about the group. In the case of members of the study population, personal attachments and experiences make it difficult for them to see issues unbiased and with "fresh" eyes. An outsider without preconceived opinions is often in a better position to assess the community's experiences and put them in perspective.

... and we hide ourselves from ourselves out of fear, self-protection, and guilt, from which it might be extremely difficult to disentangle. It might be those external to the experience that more clearly see what is occurring and can override the self-deception. (Dwyer \& Buckle, 2009, p. 59)

On the flip side, the author has enjoyed relative privileges and points of identity connections such as race, status, age, education, faith, underprivilege background and being from a marginalized community as the host community. The South South Region of Nigeria is home to most oil wells but there is poverty, lack, and injustice side by side wealth and power. These identities intersected with various participants and rightly influenced their relationships. 
These arguments are used to justify the author's subjectivity relative to members of the Westside community in conducting this study. The preceding discussions explain why the author, although an outsider in Westside, is attuned to many of the concerns of members of this community. His experiences have also positioned him to work with youths and young adults, seniors, organizations and other entities on issues affecting the Westside neighborhood. This study, therefore, is an attempt to collaborate with residents to understand their experiences and help develop ideas for a better future for all in the neighborhood.

To understand the root causes of the community's challenges requires more than a show of scholarship or business knowledge. Freire (1978), for example, emphasized the virtue of tolerance

and humility and an understanding of the issues that pose challenges for people. By following Freire, we will better understand one another, promote trust, and energize common bonds that are necessary for sustained community revitalization.

\subsection{Participant Selection}

For this study, 28 participants were recruited to take part either in the semi-structured interviews or the focus group discussions; one individual participated in both. Participants for the interviews were selected based on their direct or indirect relationship with the community; some were students in the Dunbar School during the eras of segregation, desegregation, and the transition period, or had family members or friends who attended the school. Efforts were made to include diverse participants that are representative of the neighborhood. Of the 28 participants, 15 were female and 13 were male. Five of the participants were White, and six do not reside in the community. Two of the outside resident participants live just outside the border of the neighborhood, while the other three were from other parts of the city that some of the residents have had interactions with and vice versa. The age of the interview participants was 50 years and 
older and focus group participants ranged in age from 16 to 50 years. Semi-structured interviews $(n=14)$ were designed to capture historical narratives and focus group discussions (2 groups and 14 participants total) to reveal contemporary contexts and ideas for change.

Participants for the study were recruited through both assertive and snowballing techniques. Considerable time was spent in this neighborhood as part of a four-semester servicelearning outreach project supported by West Virginia University. The service-learning project gave us the opportunity to have informal conversations with residents from our target groups. The researcher will discuss this more in the next section. Recruiting interview participants was easier than recruiting participants for the focus groups. This had to do with age, as younger folks face more time constraints because of work schedules. The researcher enlisted churches in the neighborhood as well as the youth development center as recruiters for youth and young adults to add to the focus groups. The congregations of the churches plus the youth center are representative of the neighborhood's population.

For older participants with ties to the Dunbar School, the Dunbar School Foundation was the starting point to recruit alumni for the study, using the snowball technique. The snowball technique is a non-probability sampling technique that is used by researchers to identify potential research participants. It is also known as chain method. This method is necessary because the neighborhood is close knit and connected through churches and associations within the neighborhood. 


\subsection{Profile of Participants}

A total of 28 individuals participated in the study. These are pseudonyms.

Figure 14. Profile of Interview Participants.

\begin{tabular}{|c|c|c|c|c|}
\hline Pseudonym & Gender & Race & Age & Affiliations \\
\hline Elias & Male & African American & 97 & Dunbar/resident \\
\hline Lawyer & Male & African American & 77 & Dunbar/resident \\
\hline Peter & Male & African American & 70 & Dunbar/resident \\
\hline Amanda & Female & African American & 76 & Dunbar/resident \\
\hline Ashleigh & Female & White & 80 & Resident \\
\hline Elizabeth & Female & White & 65 & Non-Resident \\
\hline Paolo & Male & African American & 65 & Resident \\
\hline Fiona & Female & African American & 75 & Dunbar/resident \\
\hline Ajijoye & Male & African American & 74 & Dunbar/Resident \\
\hline Wallop & Male & African American & 67 & Resident/Dunbar \\
\hline Sarajevo & Female & White & 55 & Non-Resident \\
\hline Magdalene & Female & African American & 68 & Resident \\
\hline Warren & Male & White & 56 & Non-Resident \\
\hline Rufus & Male & African America & 70 & Dunbar/Resident \\
\hline
\end{tabular}


Figure 15. Profile of Focus Group Discussion Participants.

\begin{tabular}{|c|c|c|c|c|}
\hline Pseudonym & Gender & Race & Age & Affiliations \\
\hline Tammy & Female & African American & 35 & Resident \\
\hline Patty & Female & African American & 30 & Resident \\
\hline Akuli & Female & White & 28 & Non-Westside/Dunbar \\
\hline Tony & Male & White & 32 & Non-Westside \\
\hline Samson & Male & African American & 40 & Resident \\
\hline Anderson & Male & African American & 45 & Resident \\
\hline Lincoln & Male & African American & 37 & Resident \\
\hline Singer & Male & African American & 32 & Resident \\
\hline Diana & Female & African American & 34 & Resident \\
\hline Sally & Female & African American & 24 & Resident \\
\hline Andrew & Male & African American & 45 & Resident \\
\hline Sonia & Female & African American & 42 & Resident \\
\hline Bridget & Female & African American & 30 & Resident \\
\hline Neon & Male & African American & 26 & Resident \\
\hline
\end{tabular}

\subsection{Pilot Study}

The pilot study was carried out to provide an understanding of issues related to participant recruitment, identify culture sensitive and appropriate terminologies, modify the design of the study, and determine what tools to use and general administration of the instruments (Kim, 2011). The researcher chose to conduct research in this community because, for two years (2016-2018) he has been part of a West Virginia University-led community revitalization effort in collaboration with the Westside Action Coalition (WAC). The idea for the study was to expand the data coverage area not covered by Fostering Fairmont revitalization efforts to include the voices of seniors and 
young adults who were not part of the project, so as to include their stories and conversation on how to develop their community.

As discussed in the case study chapter, Westside is a mixed neighborhood with a large African American community. Historically, the African American community in Westside experienced segregation, followed by desegregation after the passage of the Civil Rights Act of 1964. From informal conversations with residents, there is a strong attachment to memories of Dunbar School, in terms of its role in promoting the African American community's values. Built in 1928 to serve the educational needs of African American children, residents believe that the school achieved the purpose for which it was established. The all-Black school became the unifying institution in the community. When it was closed due to desegregation, the community lost an important center that held it together. Children were moved to a previously all-White community school and teachers and mentors at Dunbar School had to seek employment elsewhere.

For the pilot study, I focused on how to conduct semi-structured interviews with two of the participants in their homes. I compared study notes and literature on how to plan, design, moderate and analyze focus group discussions, specifically in African American communities. I worked on my accent and how to relate with older folks, especially on emotionally charged issues, and in the privacy of participants' homes. I also learned about nuances unique to African American communities. I should say that it did not take long to know that all people have accents; by "accent" I mean registers that are common and help them to make meanings different from other people.

In accordance with the stated objectives, different methods were used to understand the lived experiences and future possibilities for residents. I researched the thoughts and the oeuvre of scholarly and informal works of Dunbar High School's only administrator and integrated them into this study. I came to believe that this principal, William Oscar Armstrong, understood the 
psychology, politics, social, and economic life of the residents, school and outside of the community. One reason is that he had to work with and relate to students, parents, and teachers, who were white and black. His ideas were embedded in his speeches, letters to the editor, and opinions he wrote for daily newspapers and magazines. These writings were representations of events during his time, dealing with race, segregation and desegregation.

Armstrong was very much concerned about freedom, equality, brotherhood and truth among the people. He often prayed about this publicly when he had the opportunity. He was a teacher, mentor, motivator, leader, and activist. He had a vision of the kind of future he wanted for the youths and young men and women in the community and he expected them to pursue it. He articulated his thoughts in a speech he titled "The Anchor". He spelled out these "anchors" as career, self-respect, health and decision-making and emphasized their importance. He admonished residents and youths alike to drop those anchors at the right time in order to have a bright future (WVUHM, 2017).

W.O. Armstrong had a strong and undiluted message for Blacks and Whites, and especially for youths and young adults whom he saw as the pillars of the future. The message of love, patience, tolerance and unity permeated every opportunity he had to speak or write. His message was well received by Black and White, and the respect he had earned is reflected in the plethora of messages and remarks made after his death in 1970.

This initial activity provides the background and context the researcher needed to talk to the people, especially senior residents, picking an important point Armstrong had made and to hear their responses. For example, he asked, "What does do twice as good to gain half as much" mean? Two respondents replied immediately, saying, "That was W.O. Armstrong's slogan." The first participant cited another, "We seek the plane at the top of the ladder of success". They both at 
different times expressed how impactful, motivating and significant those slogans were to Black kids at Dunbar School.

The semi-structured interviews contextualized historical race relations in the neighborhood and how they have transcended the times. The two participants for the pilot study were 70 and 77 years old. Their experiences and perceptions of the Westside neighborhood in relation to Dunbar School yielded insights and improved our perceptions of the community. Themes that dominated the pilot study conversations included leadership, education, knowledge, school, unity, racism, classism, drugs, violence, agency, status quo, and trust in the community.

The two pilot interviews were conducted in the participants' homes. Although the location provided safety and comfort for interviewees, and assured confidentiality, there are reasons why a different venue would have been preferred. In one case the loud ringing from the land line phone virtually truncated the thought of the participant. He said aloud, "I lost it, never mind, it will come back to me..." There were a lot of emotions and sentiments shared during this interview session. It prepared us for what to expect, but only up to a point, because different participants expressed themselves differently. I add here that many of the thoughts expressed by pilot study participants are cited throughout the body of the dissertation. 


\subsection{Data Collection Methods}

Figure 16. Stages of Data Collection.

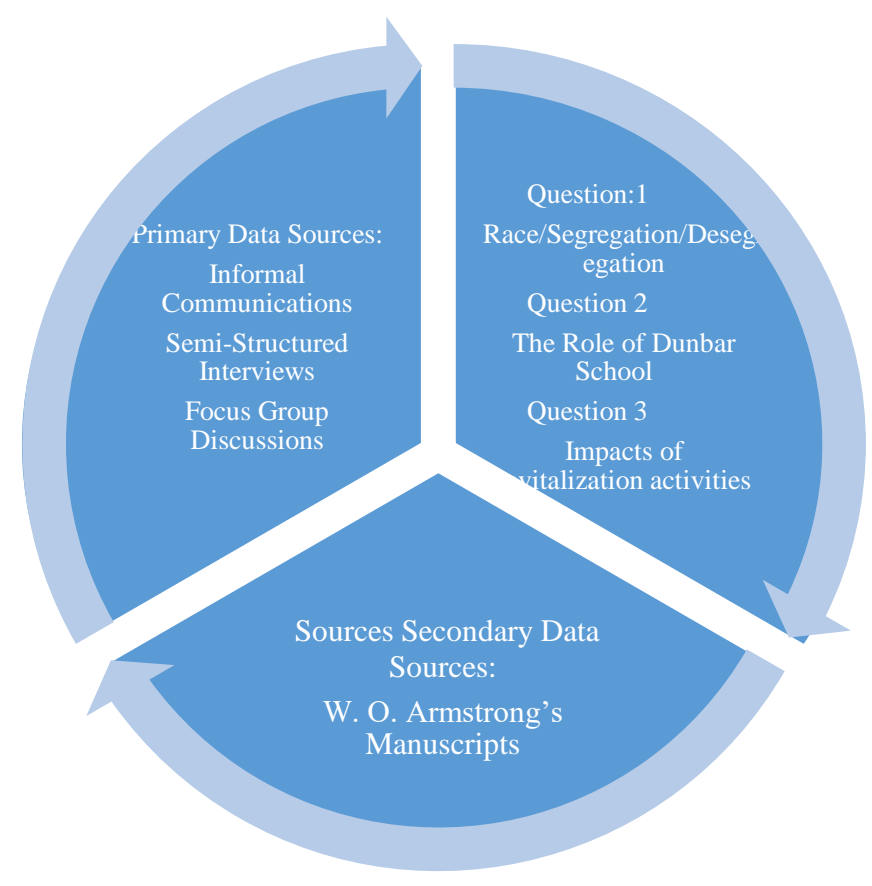

The above diagram (Figure 16) represents the research questions used in the dissertation, as well as the various data collection methods. To get to the root of historical issues in the Westside neighborhood and to understand how they have impacted the lives of residents, different data collection methods were used. These were semi-structured interviews and focus group discussions. The author also analyzed historical documents, specifically on W.O. Armstrong, who was the pioneer and only principal of Dunbar School. All the documents about him or written by him that were analyzed in this study are kept in the West Virginia University Historical Library. 


\subsection{Interviews}

Interviews are an important tool to obtain data in qualitative research. They allow us to explore views, perspectives, opinions, experiences, motivations and beliefs of participants. As Ryan et al. (2013) note, interviews are more than a conversational interaction, and the nature of the questions, questioning techniques and the rapport between the interviewee and the interviewer ultimately determine the success. The interview protocol is included in the Appendix.

Semi-structured interviews were used to gather the data. Interviews lasted between 1.5 and 2 hours. The interviews consisted of questions that covered important aspects determined by the researcher but left room for the interviewer and interviewees to follow-up points of particular interest. This format is used especially in the social sciences because it allows participants to influence the topic, which may elicit information that the interviewer had not anticipated. The structured interview does not offer this opportunity and the unstructured interview may result in information not useful to the study. To succeed with semi-structured interviews, the researcher must listen and adopt neutral body language, such as smiling or nodding, to create an atmosphere conducive to participants' sharing their experiences. Newing (2010) suggested paying attention to the interviewee through careful listening, avoiding arguments, taking time to plot and clarify what is being discussed, and promising confidentiality.

It is also advantageous to spend time in the study area to become familiar with community dynamics, which will be beneficial during data gathering and analysis (Saldana, et al., 2014). The author studied and worked in this community for over two years. This opened doors when he asked for participation in the research. Prior to this dissertation, the researcher had presented preliminary community profile findings and participated in community conversations, and the engagement strategy developed for the neighborhood by the West Virginia University led to the creation of the 
Westside Action Coalition Project (WAC). Those community presentations resulted in informal conversations about the community and created a friendly and relaxed atmosphere that was also helpful for the interviews.

Interviews were conducted with seniors in their homes. The researcher was a little nervous at the beginning about how to relate to participants in the comfort of their homes. However, the previously established relationships helped to calm nerves. The convenience and comfort of interviewees is important. The author and participants both adjusted quickly, and the author conducted 14 interviews in the space of one and a half months. It was rewarding to listen to their stories and experiences. Although relating to people who are elderly is sometimes challenging, "experience is the best teacher."

The researcher made it a point to remind participants of the duration of the interviews, which was between 45 minutes and one hour. The author also clarified the purpose of the study discussed consent and confidentiality at the start of the interviews. With participants' permission, the sessions were recorded. Some participants mentioned that confidentiality was not critical in their view.

Besides recording participants, the author also took notes that he read and listened to between interviews. Through the repetitive nature of the interviews, he was able to check and compare data in preparation for transcription. All interviews and focus group discussions were initially transcribed using Temi.com, voice recognition and transcription services. There were many typographic and context errors as a result of "accents", pronunciation, and especially because the app was in its developmental stages. This necessitated a second round of transcription where the researcher had to play and listen to the interviews and make corrections. Semi-structured interviews $(n=14)$ were designed to capture historical narratives to provide understanding of their 
lived experiences vis-à-vis Dunbar School and the community, in general. Conducting interviews in participants' homes provided the researcher with the opportunity to learn about their lives and be a part of their environments (Oberhauser, 1997). The researcher was able to relate to participants in their homes, which allowed him to ask questions about items that caught his attention while maintaining a positive atmosphere by smiling, being courteous, and acknowledging their statements by nodding.

\subsection{Focus Group Discussions}

Another data collection method used in this study was focus group discussions. Focus groups were used to gather information about opinions, ideas, perceptions and meanings that underlie community norms. Like semi-structured interviews, they are flexible and enable participants to provide details. Focus groups are organized and controlled by a moderator. The moderator must be a skilled facilitator and knowledgeable in the subject matter to ensure that the conversation is not lopsided. Everyone in the group, regardless of age or status, should be afforded the opportunity to participate. The moderator should also keep participants focused on the issues, and not allow a few panelists to dominate (Wilkerson, 1996).

Focus groups help the researcher to understand how people make sense of their experiences through their respective views and constructed meaning-making together as a group (Wilkinson, 1998). The selection of participants should ensure that the focus group is knowledgeable and representative. The literature distinguishes between homogenous and heterogeneous focus groups; both have their advantages (Wibeck \& Dahlgren, 2007). The size of the group also influences the quality of the outcome. Studies have shown that small groups offer more opportunities for participation and the discussion is more focused than in larger groups. Wilkerson (1996) recommended a maximum number of participants of eight and a minimum of five; the discussion 
should last between one to not more than two hours. In this study, focus groups consist of seven participants for each session. The two focus groups for the study were necessary based on Wilkerson's (1996) recommendations and to help reconcile the schedules of participants. The age group was the same and intended information was the same as well. There was also no reason for analyzing the focus groups separately.

The researcher did not conduct a pilot study for the focus groups, but spent considerable time researching how to conduct successful focus groups. He included readings and video clips resources (see Appendix). He also practiced techniques suggested by Krueger (2002), Kitzinger (1994) and Wilkinson (1998). These authors write about how to select participants and provide suggestions for an environment that is conducive to a focused discussion, and they list skills needed by an effective moderator. They also recommend that the moderator serve as the record-keeper.

As noted earlier, focus groups were a challenge at first, especially the recruiting phase, but the process improved as soon as participants' work schedules were reconciled. The first and second sessions took place at the Morning Star Baptist Church and Early Start Facility with each preparing us for the next session. The president of Fairmont City Youth Development Center and some pastors and members of other churches were instrumental in recruiting participants for the session and were present at the first session. It was a success because participants expressed their thoughts, ideas and feeling freely. They were respectful of one another and the process in general. The researcher recapitulated the answers to each question, which provided opportunities for comments and corrections. At the end of the meeting each participant was thanked with a handshake and a gift card approved by West Virginia University’s Institutional Review Board (IRB).

The researcher noticed that each participant came prepared to share personal stories. A couple of them also tied their stories to those of friends and family members who were affected by 
system change resulting from desegregation and from the school closing years later. Although none of the sessions lasted more than the scheduled time, it was perceived that many participants felt relieved to have shared emotions they had long held in. This was evidenced in their comments and smiles after the sessions.

Overall, the focus group discussion methodology is a good fit for this research. This is firstly because of the nature of the information he sought, and secondly because of the reaction of the participants. Some of the advantages of the methodology include: (a) the ability to highlight respondents' attitudes, priorities, language and framework of understanding; (b) the encouragement of a variety of communications that facilitated participants' tapping into a range of understanding, identification of group norms; (c) the exploration of differences between participants; and (d) the reflection upon each other's ideas, ensuring that the data is interconnected (Kitzinger, 1994). The focus group discussions were designed to reveal contemporary contexts and ideas for change to enhance quality of life in the neighborhood.

\subsection{Historical Documents}

The manuscripts of W.O. Armstrong, the principal of Dunbar School from 1928-1955, are secondary source documents that yielded information for the analysis. The manuscripts comprise newspaper articles, speeches, remarks, and tributes from notable personalities after Armstrong's death. The voice of Armstrong and the voices of the study participants sometimes differ, but they are also often in harmony across issues. The contents of the manuscripts reflect events that were happening in the neighborhood and county educationally, socially, politically, and economically during his time. These manuscripts are housed in the West Virginia University Historical Library. 
A look through the records shows that Armstrong was a central figure who played a mediatory role between students, parents, city government, National Association for the Advancement of Colored People, and Blacks and Whites. As noted by one of the participants, "There is barely any difference between students and teachers/principals nowadays." This contrasts with how it was when Dunbar School was open in the community and headed by Armstrong. The researcher considers the records of this influential personality as forming the basis for the investigation and analysis of historical events in the Westside community.

The diverse nature of Armstrong's manuscripts is noteworthy. His records include many excerpts from daily newspapers, and acknowledgements and commentaries in response to his death. Issues and daily events are constantly discussed and talked about in newspapers, especially during the time when there was no alternative media. This is the idea behind Cole and Stewart's point that "the habit of reflexivity of continually revisiting and reframing questions in light of knowledge produced or insight gained, may support an iterative rather than a linear process" (p. 371). The author should emphasize that the focus is on Armstrong and the comments and tributes to him after his demise. He considers this to be a very rich source of data and perspectives outside of current residents and different time frame and serve as the context for interpretation of data for the study.

The review of secondary data sources, such as W.O. Armstrong's writings, indicate that the community has experienced systemic discrimination during the "separate but equal" era. Discrimination in public institutions included school funding and housing allocations. Layoff decisions were also influenced by race and persisted after official segregation had ended, for example in the non-assimilation of Black teachers who had been laid off because of school integration. 
Other frequent themes include love and respect for community, race and class issues, community advocacy, youth advocacy and support, tolerance, strong sense of responsibility and high self-esteem, striving businesses, self-reliance, and hope for a brighter future. The differences between then (desegregation period) and now is that Dunbar School was open, the community was close knit, and there were teachers and mentors to help train and nurture youths and young adults in the community. W.O. Armstrong the principal, the chief administrator of the school from its opening in 1929 until 1955 when it was closed, was a strong believer in and advocate and mentor of youths and young adults', and a supporter of general community development.

Armstrong was a Boston native who moved to West Virginia with the sole aim to teach in an all-Black school. He fell in love with the state and the people, so much so that when he had an opportunity to move back Boston, he turned it down. Earlier in his career, he sat for an interview with Lough in which he described Fairmont, Marion County, based on verse 6 of James Weldon Johnson's “Creation” as God's Country. He stated:

Then God Himself stepped down- and the sun was on his right hand. And the moon was on his left; then stars were clustered about his head, and the earth was under his feet. And God walked, and where he trod his footsteps hollowed the valleys out and bulged the mountains up. (West Virginia University Historical Library, 2019)

Lough equated Armstrong's extraordinary work to Jackson, one of the pioneers and founding fathers of Dunbar High School. (The researcher clarifies that historically public schools for children of color were often named after the African American Poet and Writer, Paul Laurence Dunbar, who died in 1933 from tuberculosis.) Lough's description fits the character of a man in love with a place and dedicated and committed to the growth and well-being of the community. 
He concluded the interview by adding that Old Dunbar School, under Armstrong's tutelage was a modest school and that the successes of its alumni can be traced to the leader.

...People may will never know or begin to imagine the magnitude-in-constancy of the heart mind-and-soul wearing battle of the books waged and won by this modest, kindly, unassuming warrior. The result of that fight is evident enough though, for nowhere in the world is there a more to be admired group of citizens in kind than the men and women whose alma matter was Old Dunbar. (West Virginia University Historical Library, 2019)

Armstrong served as principal of Dunbar High School for 26 years, and as assistant principal of Miller Junior High School in Westside after Dunbar High School was closed. He also served as Judge for the Voice of Democracy, vice chairman of the trustee section of the West Virginia Library Association, president of the Marion County Public Library Board, and member of the Marion County Planning Commission. He was recognized with the Civic Leadership Award in Marion County, and was only the second African American to earn a Master of Education Degree from West Virginia University in 1942. Dr. Armstrong was a firm believer in community development but cautioned that it should be done carefully due to the nature of the society at the time. He remarked, "We should most certainly do community planning, but not rigidly because we cannot always tell what is ahead." 
Figure 17. W. O. Armstrong Papers.

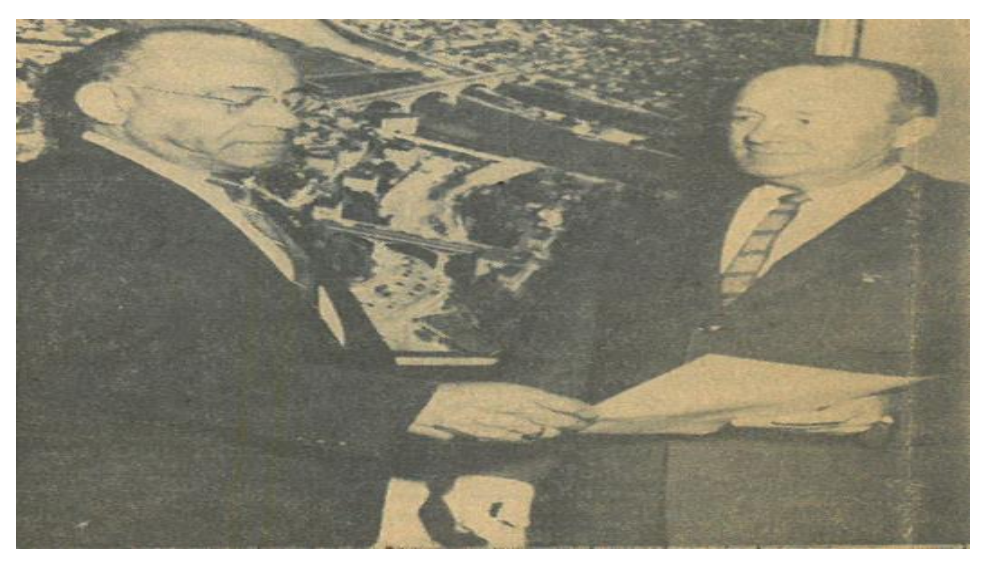

Courtesy: WVRHC

In the next section, data analysis and procedures are discussed in relation to appropriate literature and explores the perceptions of participants to establish that the decline of the Westside community is not due solely to a single cause but to a combination of causes over time.

\subsection{Data Analysis Procedures}

The primary data sources used were interviews, informal conversations and focus group discussions. The manuscripts of the pioneer principal of Dunbar School was analyzed as a secondary source. The manuscripts contain information about events that took place in the Westside neighborhood during Armstrong's life and their impacts on residents. The dissertator transcribed the audio recordings of the interviews and focus groups discussions. Pseudonyms were used for confidentiality and privacy of participants. He then compared the transcripts with the audio recordings to ascertain accuracy.

Qualitative research techniques adequately address historically grounded research. One change was made in the initially planned data collection procedures, and that was in the age range 
of the participants of the focus group. This was done at the beginning of the process to accommodate more interviewees by allowing members up into their 50s.

\subsection{Coding and Memoing}

The process of data analysis starts with memoing and coding of data, identifying themes and commonalities that emerge. This was a demanding task and an iterative process that required the researcher to immerse himself in the data (Creswell, 2009; Cohen, Manion, and Morrison, 2011). As with other steps in the research, the author took time to describe, analyze and interpret data as he progressed with the study (Rossman and Rallis, 2003). As described by Cresswell and Plano (2011), interpretive analysis involved examining data sets and providing meaning to what is discovered. the analysis was conducted based on the theoretical framework that was introduced earlier.

Responses given by members were grouped into pertinent and insignificant information. Reactions not related to our inquiries were considered not pertinent, while reactions related to the inquiries were used in this study. After authenticating the interviews and focus group discussions, related literature in issues discussed such as race, segregation and desegregation and its impact on community. Gathering codes into groups is significant because it helped the researcher to cut down on the number of units, besides their potential to explain.

Interpreting the information gathered required the researcher to understand how participants approached the questions. Information provided by participants was checked against historical data to check for agreements and differences in how events were perceived. The information was reviewed repeatedly through line-by-line examination of transcripts, field notes and memos, and documents. 
Open coding was utilized to determine how frequently specific themes were mentioned in interviews and focus group discussions (Neuman, 2004). In what could be described as the second cycle of coding, he scrutinized memos and transcripts of interviews and focus group discussions for categories and themes, then coded the data for each study question using an interpretive and deductive framework that explores race, segregation, desegregation, and their overall influences on the community. This was done bearing in mind the relationship between residents and the role of the all-Black Dunbar School that served the community from 1929 to 1955.

\subsection{Ethical Considerations}

Information gathered through this process can inform policies to effect positive change in the community and lives of its residents. This study relies on stories that reflect the perceptions, perspectives and views of long-term residents and friends, as well as youths and young adults, who live in or have other relationships with the study community. Six participants from outside the study community were included for outsider perceptions. These were from neighboring churches and city officials respectively that have some connections with study community. The privacy, confidentiality, respect and dignity of participants were a priority in accordance with ethical obligations for a study of this nature.

It would be a severe violation of research ethics to suppress, falsify, or invent findings to meet the researcher's expectations or needs (Schram, 2006). This study meets the ethical requirements and guidelines provided by West Virginia University Institution Review Board (IRB), which was approved on 09/29/2017. Participants were duly informed at each point about the purpose and expectations of the study, participation was voluntary, the researcher concealed the identity of participants in publicly accessible materials, and preserved participant responses so that they can be consulted for accuracy of how they are reported. 


\section{Chapter Five: Findings}

\section{Introduction}

The purpose of this study was to understand past and current events that continue to influence progress in the Westside community. Using the historical lens of study participants, the analyses of their stories and experiences inform the basis of the findings of this research. Primary objectives of the study were to gather information about the neighborhood's history, identify obstacles to community development, and contribute insights about building community capacity.

Specific research questions include how race, segregation, and desegregation influenced relationships and trust among residents. How have past experiences shaped leaders in the neighborhood? How have residents' perceptions of discrimination shaped the neighborhood's relationships with city government and agencies? What was the impact on the Westside community when the role of Dunbar School changed after desegregation? And finally, what have been the impacts of past community revitalization initiatives in the neighborhood?

To answer these questions, this chapter focuses on the participants' responses interview questions and focus group discussions. Before reviewing and analyzing the responses the author characterizes the individuals interviewed.

\subsection{Characterization of Respondents}

Participants in this study can be split into two groups. One group took part in one-on-one interviews and the second group in organized focus group discussions. The purpose of the one-on-

one interviews was to learn about the perceptions and experiences of senior residents whose acquaintance with the Westside community goes back 50 to 80 years. By contrast, the focus group 
discussions centered on the experiences of youth and young adults and their understanding of the community. The following Table 2 summarizes the demographic makeup of study participants.

Table 2. Characteristics of Participants.

\begin{tabular}{|l|l|r|r|}
\hline \multicolumn{2}{|c|}{} & Number of respondents & Percentages \\
\hline \multirow{4}{*}{ Gender } & Male & 13 & 46.43 \\
\cline { 2 - 4 } & Female & 15 & 53.57 \\
\hline \multirow{4}{*}{ Employmention } & No HS Diploma & 4 & 14.29 \\
\cline { 2 - 4 } & HS Diploma & 18 & 64.29 \\
\cline { 2 - 4 } & College & 6 & 21.43 \\
\hline \multirow{4}{*}{ Race } & Employed & 14 & 50.00 \\
\cline { 2 - 4 } & Not Employed & 3 & 10.71 \\
\cline { 2 - 4 } & Retired & 11 & 39.29 \\
\hline \multirow{3}{*}{ Age } & Black & 23 & 82.14 \\
\cline { 2 - 4 } & White & 5 & 17.86 \\
\cline { 2 - 4 } & Others & 0 & 0.00 \\
\hline \multirow{3}{*}{ Affiliations } & Above 50 & 14 & 50.00 \\
\cline { 2 - 4 } & Below 50 & 14 & 50.00 \\
\cline { 2 - 4 } & Dunbar School & 12 & 42.86 \\
\cline { 2 - 4 } & Resident & 22 & 78.57 \\
\cline { 2 - 4 } & Non-Resident & 6 & 21.43 \\
\hline
\end{tabular}

Source: Study Survey

The study had 28 participants; 13 (46.43\%) were male and 15 (53.57\%) were female. The number of participants less than 50 years old and those at least 50 years old were evenly split. As mentioned above, the older participants were selected for one-on-one interviews and those less than 50 years old were included in the focus group discussions.

Four participants (14.29\%) have not earned a high school diploma, 18 (64.29\%) have graduated high school, and $6(21.43 \%)$ have college degrees. All college graduates belong to the older group. At the time we conducted interviews and focus group discussions, 14 (50\%) of the participants were employed, 3 (10.71\%) not employed and 11 (39.29\%) had retired. We do not know if not being employed was a choice or if some of the three participants were unemployed. 
The majority were Black [23 (82.14\%)] and the rest White [5 (17.86\%)]. Almost half of them, 12 (42.86\%), either attended Dunbar School or had close relatives or friends who attended. All but 6 (21.43\%) participants reside in the neighborhood (22 or 78.57\%). Among the 6 non-residents, 2 were city officials.

\subsection{Major Findings}

All study participants expressed a strong bonding with the community. However, their fondness and attachments began to fade as the community declined. Many believed that the initial change - the closure of Dunbar High School followed by its reopening as an elementary school came about suddenly and did not give residents and community leaders time to respond.

A common theme that runs through the information from both the one-on-one interviews and focus group discussions is that the current state of the neighborhood started suddenly with the Dunbar High School closing, but that the resulting deterioration of aspects of the neighborhood have been long coming because of systemic racism, which marginalizes along color lines and along territorial boundaries and poor access to opportunities and incentives that facilitate and enhance growth and development. Figure 18 below shows that 24 out of $28(85.71 \%)$ of participants believe that systemic discrimination in economics, politics and social policies are responsible for issues in Westside; $3(10.71 \%)$ disagree and $1(3.57 \%)$ offered no opinion.

Figure 18. Findings with Most Agreement by Participants.

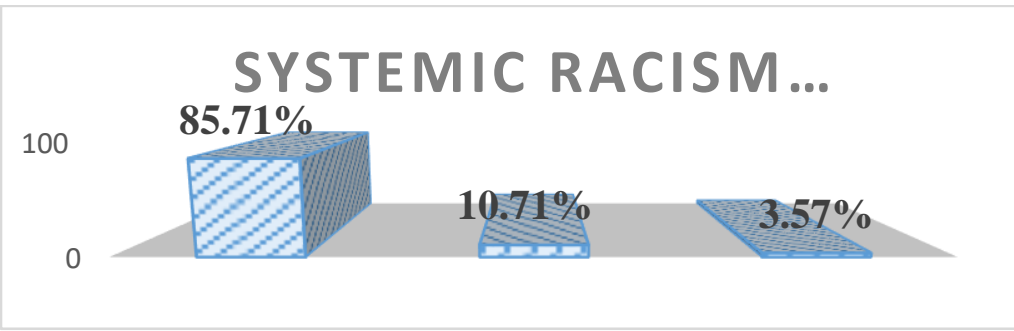




\subsection{One-on-One Interview Findings}

The responses indicate that problems in Westside are not due to a single cause, but a combination of causes related to racism. This, therefore, informed the trajectory for the sorting, grouping and analysis of themes that emanated. The tables below list responses given by participants in face-to-face interviews on experiences and perceptions on issues in the Westside community that are relevant to the objectives of this study.

Table 3(a) below reports emotionally charged issues that respondents reported affected the community. Fear of change was mentioned most often, by $10(71.42 \%)$ out of 14 participants. Desegregation and incarceration followed with 9 (64.29\%) out of 14 responses. Drugs and guns were mentioned by $8(57.14 \%)$, while apathy and fatalism had $5(28.57 \%)$ and $4(35.71 \%)$ responses, respectively. There was more disagreement about "apathy and fatalism" than any of the other issues.

Table 3 (a). Emotionally charged Issues.

\begin{tabular}{l|lcc}
\hline \multicolumn{1}{l}{ Causes } & Agree $(\%)$ & Disagree $(\%)$ & Neutral (\%) \\
\hline $\begin{array}{l}\text { Desegregation } \\
\text { Drugs and guns }\end{array}$ & $9(64.29)$ & $3(21.43)$ & $2(14.29)$ \\
Incarcerations & $8(57.14)$ & $3(21.43)$ & $3(21.43)$ \\
Fatalism & $9(64.29)$ & $1(7.14)$ & $4(28.57)$ \\
Apathy & $5(35.71)$ & $6(42.86)$ & $3(21.43)$ \\
Fear of change & $4(28.57)$ & $7(50)$ & $3(21.42)$ \\
\hline
\end{tabular}


Table 3 (b) below lists leadership and planning issues that participants believed related more and less to community problems. The lack of role models for youth and young adults as a major cause of Westside's problems-13 respondents—with only one respondent disagreeing. With 12 responses, the closing of the Dunbar School was a close second. The absence of plans to train and retain youth and young adults was also mentioned by a large majority (10 of 14). Out-migration was perceived as a problem by half of the respondents, while only four respondents mentioned race and nostalgia. Note that half of the participants disagreed that the "racial card" was a factor within the community. In the case of nostalgia as an issue, an equal number agree as disagree, and half of respondents are "neutral" about its effect on the community.

Table 3 (b). Leadership and Planning Issues.

\begin{tabular}{l|lcc}
\hline \multicolumn{1}{l}{$\begin{array}{l}\text { Causes } \\
\text { Dunbar School closing } \%\end{array}$} & Disagree \% & Neutral \% \\
\hline Lack of role models & $12(85.71)$ & $1(7.14)$ & $1(7.14)$ \\
Absence of plans to train and retain youths and young adults & $13(92.86)$ & $1(7.14)$ & 0 \\
Out-migration & $10(71.42)$ & $2(14.28)$ & $2(14.28)$ \\
Race card & $7(50.00)$ & $2(14.28)$ & $5(35.71)$ \\
Nostalgia & $4(28.57)$ & $7(50.00)$ & $3(21.42)$ \\
& $4(28.57)$ & $4(28.57)$ & $7(50.00)$
\end{tabular}

Table 3 (c) below shows more than three-fourth of respondents listing a lack of government support for the community as a major issue, followed by a dearth of leadership figures and lack of communication between development agents, city and residents. Lack of inclusion and segregation, respectively, were also mentioned by a majority. However, in the case of segregation almost 29\% disagreed with the majority. 
Table 3 (c). Political Issues.

\begin{tabular}{l|llc}
\hline \multicolumn{1}{l|l}{\begin{tabular}{l} 
Causes \\
\multicolumn{1}{l}{ Agree\% }
\end{tabular}} & Disagree\% & Neutral\% \\
\hline Dearth of leadership figures & $10(71.43)$ & $1(7.14)$ & $3(21.43)$ \\
Segregation & $8(57.14)$ & $4(28.57)$ & $2(14.29)$ \\
Lack of government support & $11(78.57)$ & $2(14.29)$ & $1(7.14)$ \\
Lack of inclusion & $9(64.29)$ & $3(21.42)$ & $2(14.29)$ \\
Lack of communication between development agents, city and residents & $10(71.43)$ & $2(14.29)$ & $2(14.29)$
\end{tabular}

Table 3 (d) reports economic concerns. The lack of opportunities received 12 mentions, followed by lack of social amenities with 11 mentions (Table 3 (d). Unemployment was third with 9 mentions. Although mine closings are an important issue in parts of West Virginia, only 4 respondents mentioned it as an issue affecting the Westside.

Table 3 (d). Economic Issues.

\begin{tabular}{|c|c|c|c|}
\hline Causes & Agree (\%) & Disagree \% & Neutral \% \\
\hline Mines closing & $4(28.57)$ & $6(42.86)$ & $4(28.57)$ \\
\hline Unemployment & $9(64.29)$ & $1(7.14)$ & $4(28.57)$ \\
\hline Lack of social amenities & $11(78.57)$ & $0(0.00)$ & $3(21.43)$ \\
\hline Lack of opportunities & $12(85.71)$ & $2(14.29)$ & $(0.00)$ \\
\hline
\end{tabular}

\subsection{Focus Groups Discussion Findings}

The purpose of the two focus group discussions was to gain an understanding of perceptions, views and expectations of youth and young adults in the community, with particular regards to the declining conditions in the Westside. A table of reasons between the two groups is 
presented here. There are similarities as well as differences in opinions both in participants' views and perceptions of the community, and what community revitalization initiatives they would like to see implemented. Overall, experiences and expectations pointed to state of lack, deprivation, marginalization, leadership issues, recreational as well as skills facilities, the role of churches, lack of influence in decision making and others as presented in the tables. 
Table 4. Summary of Focus Group Discussions

\begin{tabular}{|c|c|c|c|}
\hline \multicolumn{2}{|c|}{ Focus Group 1} & \multicolumn{2}{|c|}{ Focus Group 2} \\
\hline Perceptions & Desired Change & Perceptions & Desired Change \\
\hline Lack of unity & $\begin{array}{c}\text { Churches working together } \\
\text { among themselves and the } \\
\text { city }\end{array}$ & $\begin{array}{l}\text { Boring with no activities for } \\
\text { adults or teenagers }\end{array}$ & Focus and support \\
\hline Less us more outsiders & $\begin{array}{c}\text { Partnerships with } \\
\text { associations and groups } \\
\text { outside of the community }\end{array}$ & $\begin{array}{l}\text { Safe place to raise kids/ } \\
\text { family oriented }\end{array}$ & Organize \\
\hline $\begin{array}{l}\text { Projects priced out of } \\
\text { residents' reach/ } \\
\text { manipulations }\end{array}$ & $\begin{array}{l}\text { Equal access to current and } \\
\text { future facilities }\end{array}$ & Poor education & Galvanize \\
\hline $\begin{array}{l}\text { Withdrawal of businesses } \\
\text { from the neighborhood }\end{array}$ & More legitimate businesses & Retirement place & Mobilize \\
\hline Lack of mentors & $\begin{array}{c}\text { More role models for } \\
\text { youths and young adults }\end{array}$ & No access to technology & Mentorship programs \\
\hline $\begin{array}{c}\text { No recreational } \\
\text { facilities/programs }\end{array}$ & $\begin{array}{l}\text { Recreational facilities: } \\
\text { gymnasium, theater etc. }\end{array}$ & No mentors & Leadership training \\
\hline $\begin{array}{c}\text { Lack of voices in decision } \\
\text { making }\end{array}$ & $\begin{array}{c}\text { Representation at decision } \\
\text { making tables }\end{array}$ & Crack epidemic & Work for change \\
\hline $\begin{array}{c}\text { Lack of Commitment by } \\
\text { individuals }\end{array}$ & $\begin{array}{l}\text { Stable leaders who can } \\
\text { motivate residents }\end{array}$ & Family breakdown & $\begin{array}{l}\text { Move away to other } \\
\text { places }\end{array}$ \\
\hline $\begin{array}{c}\text { Failure to take charge and } \\
\text { embrace the future }\end{array}$ & Attitude/ perception change & $\begin{array}{l}\text { Self-centeredness in the } \\
\text { community }\end{array}$ & Stability \\
\hline $\begin{array}{c}\text { Lack of dedication by } \\
\text { churches }\end{array}$ & Accountability & $\begin{array}{l}\text { Mis-portrayal of youths and } \\
\text { young adults }\end{array}$ & $\begin{array}{l}\text { Truth, trust and } \\
\text { selflessness }\end{array}$ \\
\hline Self-imposed segregation & $\begin{array}{c}\text { Responsibilities and } \\
\text { ownership of community } \\
\text { initiatives }\end{array}$ & With-hold privileges & $\begin{array}{l}\text { City/government } \\
\text { involvement }\end{array}$ \\
\hline $\begin{array}{l}\text { Adaptability- Black or } \\
\text { white culture }\end{array}$ & $\begin{array}{c}\text { Funding sources/ grant } \\
\text { writers }\end{array}$ & Race as an issue & Partnerships \\
\hline Lack of support & $\begin{array}{l}\text { Renovation of Windmill } \\
\text { Park for community use }\end{array}$ & Apathy/fatalism & Positive attitude to life \\
\hline $\begin{array}{l}\text { Lack of church } \\
\text { involvement }\end{array}$ & $\begin{array}{l}\text { Renovation of Dunbar } \\
\text { School as a community } \\
\text { center and skills incubator }\end{array}$ & Divisions in the community & Good communication \\
\hline $\begin{array}{c}\text { Inability to build } \\
\text { relationships/network } \\
\text { outside of the community }\end{array}$ & $\begin{array}{c}\text { Youth, relationships and } \\
\text { social capital development, } \\
\text { trust and neighborhood } \\
\text { building } \\
\end{array}$ & $\begin{array}{l}\text { Uneducated/ failure to } \\
\text { launch/ unwilling }\end{array}$ & $\begin{array}{l}\text { Commitment to } \\
\text { afterschool programs }\end{array}$ \\
\hline Fear and anxiety & Support and trust & Easy place to survive & $\begin{array}{c}\text { Focus on one project at } \\
\text { a time }\end{array}$ \\
\hline $\begin{array}{l}\text { Run-down neighborhood } \\
\text { with nothing to do }\end{array}$ & $\begin{array}{c}\text { Letting go past } \\
\text { misunderstandings and } \\
\text { treat each other with } \\
\text { respect }\end{array}$ & $\begin{array}{c}\text { No election of } \\
\text { representatives of the } \\
\text { community, only appointed }\end{array}$ & $\begin{array}{l}\text { Change of charter so } \\
\text { that representation } \\
\text { could come from within } \\
\text { the community }\end{array}$ \\
\hline Underrepresentation & & Underrepresentation & \\
\hline
\end{tabular}




\section{Chapter Six: Discussion and Interpretation of Findings}

The three primary objectives of the study were to gather information about the neighborhood's history from residents, identify obstacles to community development, and contribute insights and information about building community capacity. On accomplishing this objective, we came up with five research questions around which we build our discussion of our findings. We synthesize the descriptive data from the Interviews and FGs as well as the Armstrong analysis in this discussion. Literature and theory considered for this study help us to understand the context of the community and how to analyze our data specifically on the community and make connection with other communities around the country.

\subsection{Research Question 1: How have race, segregation, and desegregation influenced relationships and trust among residents?}

Race is among the most discussed issues in the current social and interdisciplinary studies literature. Discussion of race influences or impacts relationships. We discuss race in relation to segregation and desegregation.

Social scientists generally perceive race as a social construct without biological meaning when used in human context (Wilson, 1999; Fiske, 2010). This is evident in the changes of the definition over time to reflect the ideology of superiority of one race over another. For example, it transitioned from a description of people and society to a taxonomic sub-classification of plants, animals and humans by $17^{\text {th }}$ and $18^{\text {th }}$ century and subsequently provided a "scientific reason" to justify slavery, dehumanization, injustice, and exploitation (Clair \& Denis, 2015). As Clair and Denis note, the discussion or study of race is not about a natural phenomenon, but about the various ways in which society has constructed and reconstructed the term. 
Garner (2010) opines that there is no one way to define racism. The U.S. Civil Rights Commission defines racism as any action or attitude, conscious or unconscious, that subordinates an individual or group based on skin color or race. Racism can be directed at individuals or whole groups and is particularly harmful when it is supported at an institutional level.

Contemporary social research has shown that racism shifts from individual beliefs and attitudes to social processes, forces and institutions and are expressed in policies, practices, beliefs and norms, systems, and structures (Clair and Denis, 2015). Carmichael and Hamilton (1967) define institutional racism as all instances of discrimination, exploitation, and domination based on group membership in organizational or institutional contexts, such as housing, education, employment, religion, and media.

The Westside neighborhood has a history of socially and racially diverse people. Race has been a common concern. According to study participants, race has shaped and influenced the running of the community from the beginnings of the neighborhood. History reminds us that this neighborhood was once polarized along color lines, as were its social, economic, religious, political, and educational institutions. The effect of polarization still lingers in Census Track 205, heart of the neighborhood. Despite the diversity among community members, Wallop, study participant, had this to say:

There was a sense of community, sense of a community because growing up I think the neighborhood was like most small Southern integrated neighborhoods...it was a mixed community in that community on the Westside. There was African American, there was Whites, there was Chinese, that tiny community growing up was very much integrated. So, the community integrated 
the schools at that time were still segregated, uh, the Whites in neighborhood.

The Whites in the neighborhood went to certain schools and the Blacks went to Dunbar... (Wallop, Interview, 2017)

He added:

I can vaguely remember the racism that most likely was there, but as a young man growing up, I didn't see it because when I'm growing up in that community, my best play guy was a White guy.

Another participant:

...the community itself, the community was vibrant, a community where he did something wrong with, correct you. And, "I'm telling your mom," "I'm telling your dad," "Come here, boy. No, you're not supposed to be doing the stuff." It was a real system community.

Andrew:

...It was the type of neighborhood where you can knock on your neighbor's door and borrow sugar. It was the type of neighborhood where you knew the routines of everybody in the neighborhood. When there, when someone's father was going to work, it was the type of neighborhood when you see someone's mother walking down the street and you was up to no good, you knew that hid behind the house until they got gone. And then when they got by you, I see you hide behind that house. (Andrew, Focus group, 10/25/2017) 
All interviewees as well as focus group participants agreed that the community was united, with everyone looking out for the well-being of others and the community, in general, even though they worked, shopped and went to school in different places.

Eighty-five percent of research participants believe that the current development crises in the neighborhood is fostered through systemic racism. Participants specifically believe this happens through discrimination in employment opportunities, development projects, educational and economic opportunities, and lack of inclusion and representation in decision-making.

On employment opportunities, for example, some participants stated that people of color do not have the same access to job opportunities as White citizens. They mentioned, for example, that there is only one Black police officer working for the City of Fairmont. In addition, they often remain uninformed about job openings. Finally, they cite many broken promises in anything that would have a positive impact on the neighborhood. Responding to a question about how they have experienced discrimination and broken promises a participant. responded by asking, where was the one project promised by the City to the community when the Black Elks store building was demolished? He added that this was one socialization location for Blacks, besides the promotion of business activities outside of Windmill Park and was second to Dunbar School in terms of bringing residents together (Manoyah, Interview, 2018). In his words:

...as far as Westside goes, there's been a lot of promises that were made that has not been followed through, and I think that's what a lot of people look at too is like we were talking the talk, let's work the work. A prime example here is down here at the end of the hill here, where the iron bridge, there's what used to be called Black Elks. There was like a Black club and you know, Black sailor or 
whatever. They have dances and things like that, or they tore that down. The whole purpose of this takeaway bridge was that they were going to build the hotel there because they wanted to have a riverboat casino down there because I guess whatever port taxes, and all this came into play. (Manoyah, Interview, 2018)

Our study confirmed that the Black Elks building was one of the historic buildings that was taken by the city because of the threat it posed to the community at large. According to Panuska (2008), the emergency ordinance for the city to take over the property and demolish it was a safety precaution because a portion of the parapet wall on top of the roof was crashing down into the street. A decision was reached after a public hearing. The City Council voted unanimously to tear down the building after Fairmont Renaissance Authority officially transferred ownership to the city. However, the researcher couldn't corroborate what promise was made by the city to members of the community at the hearings that led to the process.

Segregation is a direct product of racism. Pickens (1927) describes the nature of segregation as truly subjugating:

Whenever one form or degree of segregation is established it always calls for another. It is a monster that grows by that which it feeds upon, and whose appetite is not appeased but magnified by what is thrust into its mouth. Consider the schools: segregation in the kindergarten stimulates a desire for segregation in the grades; when it is established in the grades, there is sure to be a call for segregation in the high schools; then the atmosphere around the 
universities becomes less tolerant toward any group which has already been

cast out by the rest of the school system. (pp. 1-2).

Ryan (1999) concurs and notes that, “...residential segregation and the limited reach of school desegregation have helped to create schools that are isolated not simply by race but also by socioeconomic status" (p. 276).

Segregation was a legal phenomenon at state and national levels. Article XII, Section 8 of the West Virginia Constitution until 1994 stated that, "White and colored persons shall not be taught in the same school." Although this was repealed and ratified in 1994 by House Joint Resolution No. 13, Acts, Regular Session, many Whites were against ratification and voted against it (Constitution of West Virginia). Schools were segregated, as were housing, transportation, churches and access to social clubs and associations, both public and private. Thus, people were divided along color lines, which also influenced relationships across color lines in the community.

An interesting finding is that many participants believed that they were not affected and did not experienced discrimination during the segregation period which officially ended in 1965 . Table 3 (c) above shows that 57.14 percent of participants said they were impacted, the majority of them said it was from fellow Blacks and not Whites. Some say that they were either too young to realize the effects of segregation or that it had no impact because they did fun activities with other races.

I believe that it's strictly a Black thing because it starts with us the Black

people in the community. They're weak-minded, that they're afraid of success and you know, to me people can only do to you what you let them do. And for Black people I noticed we'd like to fight with this (fist) instead of this (head). 
You say when you fight with muscle it gets taken away from you, but when you fight with your head, they can't take it from you. And you know, we just don't have Black leaders in the community. (Andrew, FG, 2018)

It is safe to say though, that during the segregation period, Dunbar School was poorly funded and lacked equipment and materials that facilitate learning, relative to White-majority schools. Yet in the face of inadequacies and other challenges, the school was a model school. Community members were supportive of their school and one another. This aligns with the research of Siddle-Walker (1993) that African American communities were well able to work together with school administrators and teachers to further the success of their children and community at large.

When the Supreme Court declared segregation unconstitutional and President Lyndon Johnson signed the Civil Rights Act in 1964, desegregation became official policy and segregation was replaced by other forms of discrimination. It is worth noting that 10 years prior, in 1954, the Supreme Court in Brown v. Board of Education had already stopped legal segregation of schools and other institutions. Thus, one might assume, the focus of the transition after the 1964 legislation was the integration of schools, but many Blacks and Whites were unhappy with the proceedings, though for different reasons. The focus on schools for a long time distracted from noticing how few efforts were made to integrate other institutions and services such as public transportation, medical care, housing, and employment (West Virginia Archives and History, 2018).

Those who are equal before God shall now also be equal in the polling booths, in the classrooms, in the factories and in hotels, restaurants, movie theaters and other places that provide service to the public. Let us close the springs of racial 
poison. Let us pray for wise and understanding hearts. Let us lay aside irrelevant differences and make our nation whole. (President Johnson; cited by Gutman, 2017)

Although the comprehensive integration of society was at the core of the Civil Rights Act, as evidenced in the quote above, there was rejection or reluctant acceptance as demonstrated in lawsuits and boycotts after 1964 (West Virginia Archives and History (WVAH).

Almost two-thirds (64.29\%) of the interview participants believe that desegregation fractured relationships and trust in their community, a belief shared by participants of the two focus groups. Concerns about youth and young adults going without teachers and other adults (particularly from the same background) to mentor them, the lack of social amenities, and the presence of drugs influence how study participants perceive their treatment by government agencies. The perception that the police make indiscriminate arrests, lack of jobs and economic opportunities generally, and lack of leadership in the neighborhood, they all contribute to maintaining a cycle of poverty and a negative view of city government.

Negative relationships and low trust in the community stand in the way of fostering a community revitalization strategy because people are unsure of each other's agendas and their mutual compatibility. Elizabeth, (Interview, 2018) a White participant, sums up the neighborhood situation and ties it to the state's and city government's actions:

...the Westside demographic is the lower, the lower income demographic that struggle with life support. Most of their children are on some kind of state support, but I don't know whether you know or recognize not, but the, the federal 
government has not approved the $\mathrm{CHIP}^{2}$ program, which is the Medicaid program for children, which I would say most of the State of West Virginia children are on the CHIP program, which means that funding doesn't happen. These kids no longer have access to healthcare. It's a big deal. It's a big deal.

Participants' contributions on race, segregation and desegregation and influences on trust and relationships are holistic and draw on human and social capital-building perspectives. Both Whites and Blacks lament the poor condition of the community, stressing that the reason why issues affecting the community linger is because authorities do not prioritize inclusive development policies. As Elizabeth (Interview, 2018) notes, “...the reality is that people that are suffering and need help have these issues and so we're not creating solutions to help these people." Participants accept some of the blame for the lack of progress by noting that residents have withdrawn from participating in bettering the community.

From the participants, the researcher concludes that there exists a communication gap between residents, the City of Fairmont, and development agents. For meaningful change, there is a need to create conversations that can move beyond past experiences tied to segregation, desegregation, and race, to a future of trust in one another, building and uplifting one another in the process. Furthermore, there is a need for conversations about race because of biases and exclusion in the past and present in communities and institutions in the U.S. (Rochon, 2015; Bonilla-Silva, 2015). Although this is not an easy conversation, the consequences of inaction are continued polarization, inequality, and conflict between races. One of the major findings of the

\footnotetext{
${ }^{2}$ For information about the Children's Health Insurance Program (CHIP) see https://www.chipcoverspakids.com/Pages/default.aspx
} 
Center for Social Inclusion (CSI, 2012) study was that it is best to address race issues head-on because it puts people into a position where they work together to solve problems. In CSI's view:

The use of race as a wedge between Whites and people of color, or even between people of color, is alarmingly effective at a time when most Americans are facing economic hardships. Communities of color are disproportionately impacted, but Whites are also losing ground. If we can eliminate the race wedge, we raise the possibility of moving people around their common self-interests to support policies that promote equity and opportunity for all. (CSI, 2012, p. 5)

\subsection{How have past experiences shaped leaders in the neighborhood?}

We discuss leadership here as "influence-nothing more, nothing less" (Maxwell, 2007); as "the art of mobilizing others to want to struggle for shared aspiration" (Kouzes, J.M. and Posner, B.Z. 1987), and leadership as "a function of knowing yourself, having a vision that is well communicated, building trust among colleagues, and taking effective action to realize your own leadership potential” (Bennis, 2003).

Historical documents analyzed for this study show W.O. Armstrong as an erudite and stoic leader in the Westside community, where he wielded a lot of influence which he used towards a purposive and progressive change, and the development and advancement of youths and young adults. The idea was to present him as a symbol or style leadership that works in African American community. To the residents, he stood in the ranks of Washington and Du Bois as a unifier of every sector in the community. As noted by some of the mourners at his funeral, he was a man "full of the milk of human kindness" (Shakespeare, 1606). Another mourner, in his tribute to Armstrong said that: 
...he was one of three men who most influenced my life. I knew him as a teacher. The person who activated and pushed my desire to learn, who saw to it that I had opportunity to advance as my abilities permitted, who pave the way into higher education... (George Spencer, 1970)

Armstrong's advice to youth and young adults was, "Because you are Blacks in this country, you are going to have to do ten times better to do half as good." We also talked to them about the importance of dropping what he called "anchors." He defined anchors as important ties, services, diligence, commitment and connections that need to be established early in life, so that they stay firm like a ship in a tempestuous sea.

Armstrong emphasized the anchor of good health, self-respect, life career and decision making. On the anchor of self-esteem, Armstrong understood the problems Blacks were facing at the time including the castigation and subjugation of Blacks through biased or untrue stories about Blacks. He challenged the youth and young adults on developing self-awareness about their race by reading the works of W.E.B. DuBois, Nat Turner, and Frederick Douglas and other Black writers, to better understand themselves in American society and will motivate them to improve their situation.

Armstrong challenged the youth and young adults to drop other anchors unapologetically because their world is a difficult place. For them to survive requires good decisions and awareness of the role of their race. He urged them to know "the depth of their sea and drop anchors" accordingly, so that will be aware of their strengths and abilities, and discover their talents and values, as well as demonstrating courage and persistency. The following charge by W.O. Armstrong is encompassing: 
I have had the opportunity and privilege of consulting and working with groups of men and women who have the growth and development of our state at heart. These people are optimistic as regards West Virginia. They believe that West Virginia as a whole has an extremely bright future and point particularly to Central West Virginia of which Marion County is a part as the most promising area for the future development. However, this future growth is largely contingent upon the attitude of the citizens of this area. Are they aware of the possibilities of growth? Are they willing to devote their material and human resources to the progressive improvement of their community? Do they believe that a progressive community increases the value of all property? What is their attitude towards education? (WVRHC, 2017)

In Armstrong, his readers find a leader who exhibits leadership qualities as prescribed by Maxwell (2009), Kouzes and Posner (1987), and Bennis (2003). His audience sees evidence of his influence on people and institutions, drive and motivation, and the pursuit of change. In particular, we see him communicating with and motivating youths and young adults, and a concern with general community advancement. Armstrong was more than the principal of Dunbar School, but also an administrator and community activist. Many of his speeches and letters to editors addressed audiences other than his students.

Results of this study demonstrate overwhelming that the community has been without a leader for a long time. When talking about leadership, participants often mentioned Armstrong as an example of an effective and widely respected leader that the neighborhood missed. While some participants believed that there are leaders in their community and went as far as mentioning names, some other individuals pointed out that those mentioned are religious leaders 
who see themselves as leaders of their churches, and nothing more. Others mentioned as leaders enjoy influence outside the community but are not perceived as leaders within it. Some participants also believe that the current leaders in the community lack the unifying and charismatic attributes like those described about Armstrong. The influence of church leaders in the community is limited to members of their congregations. Therefore, working together as a community toward common goals has been a challenge for a long time. Because these leaders are identified only with their religious community, no community leader has emerged from among them.

Not surprisingly, therefore, almost three-fourth of study participants (71.43\%) mention leadership as a problem facing the community, and 92.86 percent and 85.71 percent, respectively, point to the lack of role models and the closing of Dunbar School as adverse factors that contributed to current conditions in the community. Ajijoye (Interview, 2018) during the interview emphatically stated:

...Essentially, there are no leaders in this community. There are no leaders in that community when it comes to organizing, when it comes to unifying and galvanizing and mobilizing. The confusion of leadership with prominence that somebody is prominent in the community, does not necessarily make them a leader. So, people who were prominent in the community up until the city, the form of city government change were people who had connections downtown. That's where they got their influence from. You see what I mean? So, you have a situation where the people outside the geographical community recognize people inside the geographical community because they are the more prominent and people seem to listen to them too. So, they must be a leader. 
People inside the community see that they have influenced the outside with the outside. So that makes them a leader. But when it comes to let's unite and go do something, now we go back to personalities.

The views of Ajijoye are also supported by other participants. The reason for this, many of them believe, is that immediately after Armstrong's death, some named prominent members from the community tried to organize, galvanize, and mobilize the community through sports, meetings, cleanup, and other activities. However, none of them were successful beyond a short time because support from community members was lacking as residents were divided on family lines, distrust, fear, class and the unprecedented changes sweeping through their community.

Why was there no support from the community? Some study participants mentioned that, "they were not carried along," some mentioned trust issues, and some described those leaders as "sell-outs." In other words, as stated by a few participants, they were leaders without followers. Sonia (Focus Group, 2018) attributed the community's leadership struggles to the failure of "passing the baton" as a leader died or left. She also voiced the more general concern with the failure of families teaching their children what is right. In her view, drugs, guns, and crime were introduced easily into the community because there was no one to provide leadership on behalf of the community to oppose the negative developments.

The way desegregation and systemic racism shaped minds and the community's consciousness may have contributed to its members' view of leaders. First, the community was not ready for the problematic transition that came with desegregation. Second, the closure of Dunbar School eliminated the place that had groomed leaders. The negative impact was reinforced when graduates of this school who might have become community leaders and 
teachers left the community in the aftermath. Churches in the community to which many look for leadership, were and are still not ready to fill the leadership void.

However, this does not mean that the community lacks individuals capable of organizing, galvanizing, and mobilizing members of the neighborhood. The churches, too, are bringing people together through cookouts and religious services. But many believe that they could certainly do more by uniting with one another to make their programs more community-oriented and partnering with churches outside of the neighborhood. An after-school program currently in the neighborhood, led by some young vibrant women volunteers, working with tight budget is providing after school training, and school development services to children. There is also a youth center, which also struggles to maintain services with limited resources to fund them.

Nevertheless, in the opinion of many residents, the existing leadership is insufficient to address the Westside neighborhood's needs. Based upon the personal interviews and focus group discussions, participants were unable to identify people who might communicate effectively within as well as outside of the community or who might lead efforts to secure funds through grant writing. Finally, there is nobody to unite the community through conscientization, that is helping residents to realize an in-depth understanding of the world around them by detangling past bitter experiences, mirroring the path to the future, and restoring trust among its members (Freire, 1973). We end with Sonia (FG, 2018) who articulates what she perceives as the real causes of the divisions in the community and what the community needs going forward:

I just feel that it's a matter of support that we are so fractured here that, and you have such a history. You're so familiar with one another, then you have no respect for one. It's nothing like a person can't stub their toe and get back on their feet and do well, but here there is no forgiveness here. As long 
memories there reaches, there is every person at this table, there is someone outside that the minute you open your mouth, they're putting you down, they've got something negative that they can say. The only way around that, the only way to change its course is to focused support, support. Not all of these organizations and things because you're not going to get people, WAC I thought was great. You had people coming in and doing the groundwork, so you have a good foundation. They're trying to give you an understanding of which way to go and allowing you to make the decisions, but people got tired because they did. This is my opinion. They didn't see what they thought they were going to see that it was going to happen quickly, and they got tired and they stayed home and it's what seems to happen here a lot. (Sonia, FG, 2018)

Sonia's candid opinion of the community attracted nodding of the head from other members of the group discussion. The reason why developing projects failed is because residents do not see any good in each other and cannot afford to support one another to achieve a common purpose together.

Finally, Westside Community did not only lose a singular leader in Armstrong, they lost

a dynamic space constituted by the synergy of the children, families, teachers, and principal together that was fractured during desegregation, thereby derailing the path to a prosperous future that was envisioned for the youth and the community.

\subsection{How have residents' perceptions of discrimination shaped the neighborhood's relationships with city government?}

We begin this discussion by looking at the responses and comments in the study and related this these relationships. Many participants believe that first segregation and then the 
administration of the desegregation process caused hard feelings and mistrust. They attribute unemployment, poor education, lack of incentives, lack of amenities, and lack of economic and business activities in their community to continued discrimination and neglect. This destroyed trust between residents and in people coming into the community, including officials from the city of Fairmont. There is so much animosity that prevents all actors working in the community from seeing a path to a common solution. City officials think they are doing their best, but residents disagree, partly because of poor communication and partly because of the lingering effects of the segregation and then the desegregation era. We discuss these different perceptions in relation to discrimination.

On the part of residents, there is nearly unanimous agreement among study participants that the community is underserved by city government in terms of jobs, education, economic opportunities in general, that is, with respect to almost all government responsibilities. This is reflected in the city's responses to all issues that affect the neighborhood. For example, some respondents are concerned about the city's action relative to Windmill Park and they liken it to what preceded the collapse of the community when Dunbar School and Miller School were closed. They are concerned that the current state is but a prelude to the Windmill Park also being taken from them. As Andrew puts it:

The Windmill Park area, it used to be, it used to be the neutral ground. That's where everybody would meet and have fun. And I know in the early mideighties when the crack cocaine epidemic swept through the area, um, the, the playground ended up being policed very heavily. They ended up putting chains on the entrances. They started locking it. And then, um, there was four basketball courts for the better good of the neighborhood. They ended up 
cutting the courts down, moving them on the way to the back. So, uh, to cut down the drug activity. Um, so it, uh, sort of kind of, um, took away that new neutral ground that everybody had to go and just, you know, relax a little bit. And now the park is basically stagnant now and it's only for people that are playing softball now they're making it so that it's not really ours anymore. (Andrew, FG, 2018)

Participants believe that this kind of systemic behavior by the city extends to other areas as well. For example, they believe that the local real estate industry is biased in its merchandising of homes in the neighborhood. They believe that the city labelling the neighborhood "crack alley" reinforced biased opinions and prejudice and opened the community more for exploitation. The efforts of the Fairmont City Partnership to build portable affordable homes for underprivileged and low-income families are also viewed with suspicion. As noted by a participant:

These houses range from 40 to $\$ 60,000$, they built like $\$ 40-\$ 60,000$ homes, but they're charging $\$ 100,000$ to $\$ 150,000$, that was, "Move your Black people out of the neighborhood..." because we don't do credit requirement to receive these homes and to add to that, the part of their plan was not to leave gaps and to these properties. There're too many gaps. You know what I mean? This is property that you actually can't do nothing with because without two lots you can't build out here. Anyway, so Partnership comes in and make this monopoly where people can't get no property, but then because they knew Black people couldn't afford it and ended up so when they broke in that $\$ 300,000,000$ to build these projects, Fairmont City Youth Development Center was supposed 
to get $\$ 100,000$. Never did. The community center was to get $\$ 100,000$. Never did. So, people just came in and just took what they wanted from the neighborhood and then contaminated the village where people had no choice but to be selfish themselves. (Samson, FG, 2018)

Patty (FG, 2017) corroborates the above assertion and shares her experiences as follows: That's how they started. They came into the community and said," Your house is being condemned" or "You're behind on your taxes". We're going to offer you $\$ 4,000$, and a lot of these families took it and moved to these outer places and then they closed Miller School because all the White kids were being shipped in on buses. And their parents, when the FBI [in neighboring Harrison County] came out here, didn't feel comfortable with their kids coming to a Black neighborhood and seeing what was going on here so that's all? That's how they broke up the neighborhood. That was the way to. They start cutting down the trees because of drug activity that can't see what's going on and there were cameras up and up into the telephone poles, so they could see what was going on in the neighborhood so that they really pushed everyone out and then after they built these homes, we tried. We applied for one of those homes. We couldn't afford it. We worked and made so much money because, so we had to move out of the community. We made too much.

Participants feel that the Fairmont city government's actions divided and marginalized the community; this was reinforced by not making new opportunities available to residents. To explain their impressions, participants make comparisons between the Westside and Eastside neighborhoods in terms of infrastructure development and the presence of amenities like Splash 
Park - a popular city-owned water park - and theaters and businesses that serve the needs of Eastside residents. Eastside is a mostly White neighborhood. Thus, many participants perceive it as a huge disadvantage to be African American living in the Westside neighborhood. Reacting to the question of how the city has been supportive of the community, Tammy and Diana (FG, 2018) summarize their perceptions as follows:

Tammy: I'll tell you how they do it. When we need $\$ 400$ to buy trophies for our football team. The only football team from district three, they gave us $\$ 25$.

Diana: I feel like we're underprivileged, we don't get certain privileges that other districts do and the neighborhood that other, other communities get an enabler. We don't, you know, there are times we don't hear about certain events and we found out from a third party outside of our demography...And the only reason why they remotely have been involved in what we've done from FCYDC (Fairmont City Youth Development Center) is mainly because when the WAC got started and WVU became a part and everything, we had that big name come in and over and over. When they heard WVU and the President and his work and that's when they started giving us some attention. As you can see that things don't want to say since things have quieted down here saying, “Oh, we'll come help," you know. What I'm saying is even now so much harder to get a hold of the city manager when before, I just call down there or I just send an email and get a reply about five, 10 minutes now waiting days before we get replies. 
The city representative refutes these perceptions and claims that it maintains its commitment to serve the need of everyone who lives in the city, without prejudice. Sarajevo, a city official (Interview, 2018) thinks that there are lot of people in the Westside community that want to see good things done in their community, but do not know how to effect change. She believes there's a disconnect between the vision and action of the people. There is, however, a sense of recognition that the neighborhood may have been marginalized in the past, but that things have changed for the better over the last twenty years. She also believes the city council is doing its best to ensure that Fairmont is a tolerant place, educated, and open to all races, religions, and ethnicities. It also works to ensure that the city is a safe and livable community by spreading infrastructure development to every part of the city. No neighborhood within the city is to be forgotten and the City Council strives to increase efforts to invite all residents to public meetings and reaching out to the city's different communities.

Although the city has no specific plans on how to inform residents of community related issues, all job openings are usually placed on the city's website and sometimes also announced on radio and television. Often the city also distributes flyers in neighborhood churches to make sure the information is widely available. Information is also passed on by word of mouth. However, the city is not aware of how much of the information reaches the people who need it, and city officials express shock that many people of color do not take advantage of those opportunities. Part of the shock was the realization on the part of the city that:

As of two years ago there were no people of color that worked for the city.

And then now we have, you know, Latino that is our city manager. We have an African American policeman. So that's, it surprised me. I was really surprised and uh, but I don't know how else we don't know, aside from, you 
know, you advertise the jobs, but um, you know, and I don't get to see who

apply or anything, but um, I don't know. I mean I don't know how to fix that

aside from getting the word out and try to make people apply for these

positions now. But I understand that. (Sarajevo, Interview, 2018)

Some residents agree with the claims made by city officials and state that some members of the community have stopped trying to improve themselves or support the community. This implies defeatism and apathy, and maybe also fear of change. Nevertheless, residents believe that there are resources in the community, but only if community members work together, instead of trying to play the "race card". This is how Tammy (FG, 2017) put it:

Tammy: I don't think that any of the men in the community are interested in giving back to the kids that don't have, um, in the very few, you know, what I mean? And then if they do about a hidden agenda and I think that that is a breakdown in our county, in my opinion, I feel like the family has fallen apart. I don't feel like the men around here to stand up and take responsibility. I always say it takes a village.

Some see the reason for withdrawal in the community's division which has lasted long enough so that they feel it is not about the community anymore and there is no need to apply for those jobs or do anything at all. As the data in this study indicate, when Dunbar School was closed after the Brown v Board of Education ruling, no effort was made to orient and integrate the community to a new order. In addition, except for schools, other institutions and organizations were not integrated. Outside of schools, the lives of Blacks and Whites continued as if nothing happened. Black children suffered the most because they were the ones who had to leave their schools and attend new schools where they were in the minority and often excluded 
from leading positions in extracurricular activities (Ajijoye, Interview, 2018). They had to search for a new identity without receiving much support in this endeavor. At the same time, community members were struggling to find help with personal and community problems. The inability of the Fairmont City Council to offer assistance created fear, anxiety, suspicion, and distrust on the part of residents. As time went by, lack of communication only served to increase these negative feelings and perceptions.

It is worth noting that although African American residents of Westside have proprietary feelings about their neighborhood, they are in the minority and Whites are the majority among residents. The feeling among African Americans comes from shared experiences and similar perceptions about the city government. Ninety-five percent of participants believe that the city could do more to improve its relationship with Westside community and that doing so would bring about positive change in the neighborhood.

\subsection{What was the impact on the Westside community when the role of Dunbar School changed after desegregation?}

Another possible heading for this sub section could be "the current state of education in Westside neighborhood." After desegregation, Dunbar School ceased to serve as the hub of the community. We saw in the analysis of the role played by W.O. Armstrong that the community depended on the school and its leadership for its sense of community in education, cultural and social activities. Thus, they formed emotional ties and came together organizationally and collectively as a community. The community worked in collaboration with the principal and his administration, teachers, and staff of the school to keep it functional because residents believed that the future of their children and that of the community depended on the existence of a successful school. 
Black schools served as the instrument through which professional educators discharged their responsibility to their community. Black educators labored to help students realize their achievement goals. In this role both principals and teachers were mere but profound extensions of the interests of the Black community. (Irvine \& Irvine, 1984)

To the community, therefore, the closing of Dunbar School was like the future had come to an end. For the teachers, principal, parents, and students it disrupted their careers and ended a cherished community-school relationship. Not surprisingly, therefore, $85.71 \%$ of study participants believe the school closing was detrimental to the community's education and aspirations, as well as to them as individuals. Another $92.86 \%$ believe that the absence of role models and mentors are among the reasons why the community is struggling, and $71.42 \%$ perceived the lack of programs to train and retain youths and young adults as detrimental to their community. Undeniably, other factors, such coal mines closing, contributed to the decline of the neighborhood. More than half the participants believe Dunbar School was more than just a school, but a path to the future, the communication hub of the community, and its cultural centerpiece. The school connected with and was committed to the community's youth and young adults by helping them develop and learn to care for themselves and their community.

The school closing also hurt leadership in the community. The stature of Mr. Armstrong as a leader is certainly due to his personality and strengths, but his acceptance as a leader cannot be separated from his role as a high school principal. In this role he had legitimacy in the whole, while a pastor's legitimacy is initially tied to a congregation and few religious leaders manage to exercise leadership beyond its boundaries. As the principal of the neighborhood high school, 
Mr. Armstrong could represent the community's interest with more credibility and legitimacy than other neighborhood leaders.

Many residents did not see desegregation as a "parting of the Red Sea" that allowed them to enter previously white schools. The following exchange between focus participants connects the changes following desegregation to the current state of education in the community.

Magdalene: Frankly, we had more experience doing the things that our teachers knew how to do, which were many things I said. In fact, this was the irony of the whole thing. They thought that the, uh, the requirements were teaching, they, they assumed that the Dunbar teachers would not have those requirements. And it turned out that the Dunbar teachers, although they couldn't go to WVU, couldn't go to Fairmont State during those times, but they had gone either to Princeton or to Columbia University. Stayed in the homes of Black people who would board them in and had gotten their master's degrees and some of them had masters Plus 45. And they found out that most of the other teachers were teaching on normal certificates, which works, you know, that wasn't, wasn't getting that many likes. But yet, our teachers were not placed in the places where their educational requirements should have placed them.

Rufus: W.O. Armstrong made the requirement that you have to continue your education to teach. The kids are coming in, so you know, hey, we had, we had the best of the best, we had discipline, love and we had learning. You go in 
any of these schools right now. You can't recognize your teacher from the students and discipline and learning. Forget it.

The last straw was that Black teachers were not assigned to White schools, where they could have helped Black students with the transition to a new learning environment. Instead, they had to re-orient their own teaching careers. The ripple effects of those actions and omissions on the part of the board of education and the lack of visionary leadership in the community together led to the decline of the Westside neighborhood. Unless the void created by the loss of Dunbar School some fifty years ago can be filled, the decline of the community will continue.

Thus, desegregation did not help education in the community, but instead further set the community apart from the rest of Fairmont. The systematic neglect has not escaped the attention of concerned parents, who foresee the impending outcome to be unfavorable to everyone, regardless of race or ethnicity. Elizabeth (Interview, 2018) a White participant who does not live in the community and whose child does not go to Watson Elementary observes:

Some of it is the political divide because it's interesting that all the Westside kids, they all go to Watson Elementary School. They're all at Watson, all. And, and even as you drive down, like I said, Fairmont State at one point, one side of the road puts you at Jane elementary. The other side of the road puts you at Watson. This is a huge concern to parents...

Every child from the Westside goes to Watson Elementary, which is the lowest-ranked school in Fairmont, far below the other six elementary schools. Participants complain that many students are placed in special education programs. This has a psychological effect on youths and young adults. School children who have been victims of politically motivated educational 
disadvantages suffer and parents seeking to escape their bleak reality may resort to drugs. Parents also perceive that not all teachers are giving their best to educate their children. The situation is aggravated by the lack of opportunities upon graduation, which has some children question the need to go to school at all when there is "nothing for the Clack kids" after graduation. Sally (FG, 2017) describes education at Westside as follows:

...education here sucks. I'm telling you, if you take your kids out of here and take them to another place, you will see. Education here is horrible. If you never leave here though, you won't understand, you know what I mean? You don't understand because the, what they learn here is nothing compared to anything that you learned in other places.

This perception was supported by Sonia (Focus Group, 2017) who believes that the quality of education offered to the children is poor:

I would say, um, the educational standards are lacking, and it affects, it affects everybody because you can't get out of here if you don't have proper education, if you don't have a strong educational background.

Sharing her children's experiences as told to her, Diana (Focus Group, 2017) concurs with Sonia on the compromised education of children from the neighborhood:

...they play our kids to a point where it's like, well, you don't have to work hard so just do it this way and just get your, not even basic, barely get an education by going to the $\mathrm{ALC}^{3}$. Don't have to work hard. Then they become

\footnotetext{
${ }^{3}$ ALC stands for Alternative Learning Center which, in this case, is the Barnes Learning Center of the Marion County School District [https://www. marionboe.com/barnes.html].
} 
a go to high school and then they go and do the same thing in high school. And then when they get ready to go out into this world, they are not ready. They can't even go and pass the standard tests, Um, employment test at Subway, which is basic math because they went to the ALC and they allow them to write definitions out of a notebook or did the very bare minimum of two plus two and three plus three and didn't equip them with the knowledge. Like I was so appalled when my son asked me then I was like, "Why would I let you go today? I will see what I know that you're smarter than that." (Shocked from what her son told her; she had no reason whatsoever to send him back to that school.)

Unlike Sally, Sonia, and Diana, Elizabeth (Focus Group, 2017) believes that the teachers are doing their part, but challenges systemic grouping of individuals within the city as an issue that needs to be addressed:

...the teachers are good. But when you have a grouping of children or grouping of adults that are coming from and struggling from the same things at home with all these varying, whether they're even getting to school or not, you know, all this stuff, it's really hard to educate them when they're hungry, tired, hurt, frustrated, watch mom overdosed on the couch and no I have to get because I'm the oldest child, make sure I'm getting everybody up and getting him dressed and getting them out to the school so nobody else knows what's happened to mom or dad or you know, or whoever. Um, those are real 
Although Sonia is one of the parents questioning the quality of education, she believes that several of factors are responsible. In particular, she believes that parents and social media should take a share in the blame:

I blame parents for not taking an interest in their children's education and setting the standard if it's OK with you that I come from when I get home and you get in from work and it's a cursory question. "Did you do your homework?" "Yep." "OK”. Nobody's checking. Nobody's. Nobody's helping the student. And maybe some of the parents can't, but then that should be the parents responsibility to go and get help for themselves as well and not keep saying there's nobody here that can help you because we're here and it's, it's, it is something that you see day-to-day and today I'm not interested and tomorrow I'm tired and after that I gotta do a, b, c, d and e or go ask somebody else.

We understand from the literature that many factors are responsible for youth and young adults' academic performance. In the case of African American children, and maybe other ethnic minorities, whose parents experienced segregation, there are often differences in the manner and quality of education received. For example, students in segregated schools saw their teachers as caring, supportive, and disciplinary figures; they believed that their teachers saw them as intelligent and knowledgeable and were motivated to succeed academically and professionally (Lyles, 2013). In desegregated schools, African American kids often experienced the exact opposite. To address academic under-performance of African American children, we therefore need to understand the psychological impacts of the transition from segregated schools and how it has shaped the minds of their graduates. 
In summary, the current state of education in Westside community is complicated and detrimental to the growth and well-being of the community. An African proverb says that if two elephants fight, the grass suffers. In this case, the children are the grass and they suffer because of the uncertainty about their future that results from the subpar education they receive. Fingers are pointed, but nobody seems to be taking responsibility. As it stands, the end of the struggle for education is not in sight as Sarajevo (Interview, 2018) alludes:

...we just did our comprehensive plan and we do talk about and that's our plan for the next 10 years and we do talk about having a tolerant place in, you know, making Fairmont a tolerant place, educated, open to all people, all races, religions, ethnicities. part of it also is the infrastructure, trying to make sure it's a livable community and making sure it's not forgotten, I guess. But in terms of safety, I mean there's, we're trying to make sure everybody's safe in the city, but in terms of educating the community like that, I mean, I don't know that I have specific plans for that. Um, you know, aside from just continually reaching out and inviting the city councils and public meetings, but my office doesn't really. We don't really do that with a lot of neighborhoods, but I think it's just continually trying to dispel the dis-trust maybe between the city, but it's just trying to make it better.

\subsection{And what have been the impacts of past community revitalization initiatives in the neighborhood?}

Over the years, there have been some community revitalization ideas implemented in the Westside community. Some of these initiatives were led by members of the community but many other could not be realized because there was no support from residents. Some participants 
believe the reason why programs fail to live up to expectations is due to absence of stable leadership and resources to keep the programs functioning. These community organizations include, United People Welfare Rights Organization, NAACP, Fairmont City Development Partnerships and Westside Action Coalition. These associations are highlighted because of their impact according to community members.

The United Peoples' Welfare Rights Organization established the Hills Bulldogs which, was a youth football club in the community. The purpose of the association was to provide a funding base for the Hills Bulldogs. The organization was actively involved in the community socially for some time before it fizzled out. 612 MAC (612 Madison Avenue Center) was another association that pulled people together through programs and activities. Hershel Walker is credited by some participants as its founder. According to them, he was the last person to have influence and attract people from inside and outside of the neighborhood to sit on board and be involved in a development process. Despite its popularity among residents and the support it provided to the community, participants believe it had little impact on the preparation of the community for future challenges and lacked support and encouragement from residents. It finally collapsed when it got tangled in monetary issues. Example of some of the attitude of residents to community efforts during 612 MAC days is captured in the story by Ajijoye (Interview, 2018);

Years ago, what used to be 612 Mac was having a fundraiser. And a couple that was prominent at that time; So, the discussion came down to," How much are we going to charge for a hot dog?" And I get this, "How much are we going to charge for the hotdogs? OK...65 cents or a dollar?" The discussion was that some residents were saying that's too much money because kids can't afford it! Until the leader said, wondering, have you seen 
what these kids what they are wearing? Jordan's and Nike's and this and that and the other. So basically, what he was saying was they were not asking them for something that they don't have all he was asking them and everybody else was to redirect some of their resources into community effort.

Wallop's (Interview, 2018) story of 612 MAC (Madison Avenue Center) corroborate that of Ajijoye but it is slightly different from the unwillingness of residents to respond positively toward community improvement, in that he painted a picture of what was not right with the organization and suggested what could have made the association more significant to moving the community forward:

$612 \mathrm{MAC}$ at the time of inception maybe for a period of 20 years probably did some good, but not enough. $612 \mathrm{MAC}$, if you go back and look at the history of it and look at its track record, it probably doesn't have one. Nothing of any significance. What came out of that probably was a little good, but then there was also a lot of chaos. Accusations of people stealing money... It had very little impact on the community over the years because if it did, you'd be hearing and writing about it.

Wallop's reasons why both 612 MAC and FCYDC (Fairmont City Youth Development Center) failed to make impact include lack of knowledge and expertise in community development. He states:

...here's why the Fairmont Youth Community Development center or 612 MAC never impacted the community because on those boards. There are three things you need for an effective board member. First, you need some 
white people with some connections or some resources or you need some Black people with a whole lot of money and community development knowledge. You need a combination of those two or one of the other, the first one that I mentioned is a preferred one. But when you put a lot of people on the board, you know, and those people, I don't discount them because they're given their service to the community, but they don't know nothing. (Wallop, Interview, 2018)

The National Association for the Advancement of Colored People (NAACP) Fairmont Chapter has been in Westside and involved for some time as well. According to participants, the association's role has been reduced to participating in MLK Day and hosting an annual dinner but it lacks the knowledge how to bring the community together. The quote below is how a participant feels about the association.

...they asked us to join NAACP. I didn't even know we had any NAACP. My question was, what have you guys been doing? I didn't even know. I haven't seen it, so if I don't see any work's being done, what is going to motivate me to do it other than wanting to do it. I'm saying to make a difference, you can't have a stagnant group. Someone is going to have to take charge and say this is what we're going to do about it. Come to an understanding and make a plan and go out and lead. We can't talk about it and not do any action behind it. And that's where I see with mostly Black people. (Bridget, FG, 2018)

Fairmont City Youth Development Center (FCYDC) is a youth target organization that still supports some after school programs, like computer training, sports and skills development 
for youths and young adults. Some of its challenges have been resources, leadership, stability and lack of support from members of the community.

The Fairmont City Development Partnership is a nonprofit community development organization that constructs affordable housing. It has been in the neighborhood for over 25 years and has invested millions of dollars in the Maple Avenue and Jackson Addition areas to remove blight and improve aesthetics. Many participants believe that the Partnership is self-serving and city-serving and does not have good intentions for the community. Some cited unkept promises, lack of communication and involvement of community members in negotiations and consultations prior invading the community and lack of job opportunities for community members. The Partnership disputes such claims and stresses that they have best intentions for the community. Warren (Interview, 2018) explained the commitment of the organization to serve the community and the benefits they hope will come to residents:

...we have the best interest at heart for the community that this is, these will be the benefits. This isn't like anything we've ever done before or that anybody's quite ever done before. This is how it will benefit, and this is what potentially this development will spark other interests hopefully, and the key to economic growth. So, when trying to build your credibility, you got to explain what is happening and go against maybe what's been misrepresented or misunderstood in the community. So, part of its reach out to community leaders, um, and have a consistent message that is a truthful, honest message of what will happen if the development goes through or this happens.

Warren's views were corroborated by the executive director of the organization in a letter to the editor, in an effort to dissuade fears about affordable housing proposal. Although these are 
the right things to do, but there have been lapses in application of these messages, that is, the way in which information is circulated within the community. The reason for this may be in part due to the current state of the community where leadership and trust in one another is lacking, or the strategies used by the organization for disseminating information is faulty.

The affordable housing proposal was approved by the city despite opposition by some residents. There is no doubt that affordable housing is good for the community, especially with the many dilapidated houses scattered around, but residents are not comfortable with the manner in which the Partnership goes about it. These include not having conversations with them and especially, not having concrete plans with them on how to manage deteriorating buildings in the community. Residents feel it is a systematic way of taking their community, especially when many of them can't afford the cost of the new buildings.

It does not matter how good the letters to the editor and community sounds. What really matters is how much of the relationships, actions, programs and resources that benefit residents and their community. In community development practice, it is always a good idea to use different ways and methods to communicate often with residents, and there is no such thing as overcommunicating in resident-centered community building (Kubisch, et al., 2013). Developers, like the Partnership, have to look at the issue from the perspective of residents to really understand how it feels like (Samson, Interview, 2018). Per findings, residents have learnt both from personal experiences and stories how developers treat communities like theirs and have become wary and suspicious of anything that looks like it. For example, studies show that many African American communities as victims of land ownerships (Copeland, 2013; Lewan and Barclay, 2001; Cola, 2017). This pattern of behaviors to African American continues to plague their existence and residents are familiar with the trend. To achieve positive results in 
issues like this in Westside, the Partnership has to carefully and respectfully work with all stakeholders in the community. However, some residents are hoping for a positive change to come with the new Partnership. This is how Ajijoye (Interview, 2018) sums how it all started and probably question the effort of the partnership and also pose a challenge to other residents:

So there have been efforts to revive, to revitalize the Westside and the fair mind community development Partnership took a giant step in that direction, but their primary focus was housing and, and what was, it seems like what was overlooked is that every problem is connected in some way to every other problem. And if the only thing that you do is, is improved housing than what you do is you take people who have no sense of legacy, no sense of ownership, and you put them in a nice house, but you really haven't changed the culture. You haven't changed anything. It's just that people used to live in substandard housing, now they live in standard housing, but the value system is the same. And so that's what has happened.

The West Virginia University-led Westside Action Coalition, also referred to as Fostering Fairmont Project, was another community revitalization initiative that took place in the neighborhood. This was a four -semester program aimed at organizing, mobilizing and galvanizing the residents using assets within the community such as natural, cultural, human, organizational, social, political, financial and built capitals. Eight short- and long-term projects were jointly chosen and a strategy for sustainable development of the projects was initiated. Although, the project was well received in the beginning, interests and support from residents decreased and faded out towards the end of the project. Some believe the project was an eye- 
opener to some of their realities, helped to call the attention of the city to their situation, though there are no changes yet.

Rising Stars is a community initiative that is currently serving the needs of children and young adults in the community. This is an after-school program that intends to help educate, train and socialize youth and young adults in the neighborhood. It relies on small grants put together by a few committed women in the community and a VISTA worker to keep its service. Some residents boast of the good work that the people involved with the program are doing, but the program like others before it, still lacks support from the community and the city. Some participants lament the systemic problem that make it difficult for people to come together and find solutions to common problems, regardless of color or status.

The Dunbar School Foundation is run by alumni of the Dunbar School who acquired ownership of the school building from the city. For the past ten years or so, the foundation has been searching for funds to renovate the building and convert it into a community center that could house a history museum, a gymnasium, an auditorium, and kitchen and skills development acquisition areas for youths and young adults. Again, like other projects, the support has been lacking from every angle.

The Foundation is not able to match potential grant opportunities and the wear and tear on the historic school building continues to deteriorate by the day, adding to the once estimated 4.5 million dollars renovation and maintenance costs. Some participants believe the reasons why the building was relinquished to the Dunbar Foundation was politicized, having projected that the foundation would not be able to gather necessary funds to renovate the building. The other reason participants speculate is that the city chose not to draw attention to itself and prevent unnecessary uproar from residents by demolishing the building. 
As a result of the circumstances described above, some participants suggest alternative solution, such as using sourced funds to demolish the building and use it to build a smaller property that could still serve the purpose of a community center and still immortalize the memories of the Dunbar School and its alumni. This, according to their estimation, will reduce renovation costs and provide extra funding for the running and maintenance of the building.

\subsection{Summary}

The researcher has established that the perceived underdevelopment of the Westside community is the result of more than closing of mines that resulted in job losses. Rather, residents perceived a systemic political structure that favors discrimination in employment, education, social, economic and infrastructural development as responsible factors. Secondly, there is a community that exists geographically but has lost spirituality and a common bond to fight to improve its individual conditions and that of the community. Thirdly, purposeful leadership ceased to be the yearnings and aspirations of residents like when Dunbar School was the hub of the community. We see fractured relationships and lack of trust in one another. So also, the role of churches and other organizations diminished from serving the community's spiritual needs and social support to serving only members of immediate congregations. We see decline in collective will, believe and trust in one another's ability to play a part in moving the community

forward. Nevertheless, we also see a community that is divided among itself and refuses to take responsibility for its own inaction. This is how Ajijoye (Interview, 2018) describes the current state of his community;

...the people who live on Shadyside, and particularly the people who live in

Sterling Heights at down slope down to Cleveland Avenue, they don't consider

themselves as part of the same neighborhood as Jackson Addition. So, there 
has not been an effort to do well, there was, but it failed and effort to make, to turn those physical neighborhoods into a spiritual community and transform that physical community into a spiritual until that happens it's going to be seen as this fragmentation.

Further, many Westside residents believe that the Dunbar Miller School in their neighborhood were closed due to desegregation, but without the desegregation of churches, housing and employment, educational and income inequalities persisted. Perceived or real differences in opportunities, privileges, and rights between residents in the Westside and the predominantly white Eastside neighborhood caused even more social division but have never been investigated. To many of the residents, the decision to close Dunbar School, the only school in the neighborhood that represented their values, heritage and future, was harsh and unimaginable. The consequence was the severance of children from the contribution of their parents to their education.

Overall, this is a community that is split within itself and drained of potential community builders due to lack of opportunities, career path, jobs and motivators. Those left in the community are divided on all fronts with no one believing in the other to the point of working to achieve a common goal. What is left behind is the current state of the community. Andrew (FG, 2018) further paints the picture of the community as weak and fearful but not without suggesting a path forward;

We need stability. We need to appoint someone within the community that's not gonna be here a year and leave. And that's been the problem. It's always been a revolving door with all the leaders in the community. You know, it started with certain leaders. I'm not gonna mention any names, but they're here 
for a season and when their season is over, they're gone. And then you leave. It's like a soldier on a battlefield who's been deserted by, by the captain of the platoon. They're in disarray, they don't know what to do. And then they're all at each other's throat and that's what's going on right now. We need to elect someone within the community that we looked up to, respected that doesn't have a shady background that is there.

It is safe, based on findings of the study, to conclude with the following statements. There is power interplaying with potential action in the underdevelopment of Westside community. A variety of individual views and perceptions of residents on development issues in the Westside are true based on their experiences and observations and thus they provide us with some insights into some of the causes of underdevelopment as well as useful information from which to initiate plan of action. It is important to mention that residents have ideas and suggestions on how to combat some of these problems they identified. These will be discussed in the next chapter along with insights from the literature and possible policy implication and recommendations. 


\section{Chapter Seven: Implications, Recommendations and Conclusions}

The results of this study are based on the 28 residents of Westside neighborhood who shared their history through experiences, stories, and perceptions of what it takes and how it feels to live in Westside neighborhood. I also analyzed the manuscripts of W.O. Armstrong, the pioneer principal of Dunbar School. Attention was paid to the analysis of their narratives to maximize the meanings, themes and categories that emanated from the conversations. Research questions and objectives of the study were addressed with careful attention to details and sensitive issues that matter most to residents. Although not directly part of data analyzed for the study, personal communication with residents and nonresidents alike, which span the period of two and a half years, have had a tangible influence on the general overview and approach to the research.

\subsection{Implications}

Findings of this study have implications for potential positive social change on individuals, family, organizations, the community, city, county and the state at large. The roles of these areas are explored below under possible path forward.

As established in the previous chapter, the decline of the Westside community has been attributed by its residents to systemic issues of social, economic, educational, and leadership problems. This researcher believes that systemic structures are products of policies that may have been formulated without careful consideration for all in the area, even as many changes were taking place. Reiterating participants views, the researcher stresses the fact that systemic racism wields significant influence over other issues faced by the community, this makes community revitalization effort difficult to put together in the community. To some members of the 
community, it is either the suspicion that community development practitioners coming into their community have secret agenda or a withdrawal attitude, under the notion that their opinions do not matter or they believe that nothing good would come out of any initiative that will benefit them.

The researcher concludes that the disposition of these residents above are tied to their past experiences shaped by policies and practices that have marginalized the community for a long time, and there have not been any effort to modify or change those policies to accommodate the community, even after Dunbar School was closed. The decline of the neighborhood started when the school was closed because social, economic, education, leadership, followership and cultural well-being of the community was synonymous with the school.

The outcome of the study shares semblances with the results of the community survey carried out by Westside Action Coalition to ascertain residents' opinions on the civic health of the entire Fairmont in 2015. Specific areas of concentration of the survey were infrastructure, education, information dissemination, leadership, relationships between the city, businesses, organizations and involvement of residents in programs and decision-making processes that affect the city. The report showed overwhelming inadequacies in all the areas tested for the whole city, but with most significant negligence of Westside community in comparison to the Eastside. Watson Elementary School, for example, is the school where all children from Westside attend. It is rated below average both in school quality, students performances on tests and services rendered to them by teachers in the entire state of West Virginia (Great Schools, 2019).

Findings of the study share traits of previous and current studies that identified structural ways through which marginalized communities experienced systemic racism and inequality, and how these practices shaped their attitude within themselves, leadership and towards general 
community revitalization initiatives (Kruse, 2019; Lowery, 2014; Sienicki, 2016; Moynihan, 2018). By the same token, the study does not in any way attribute blame for any wrong doings or cultural practices or self-imposed limitations on the part of the Westside residents. This study succeeded in pointing out some of the things that could be done to facilitate the development process in Westside neighborhood.

Suffice to add that although the Moynihan Report (released in 1965) attracted lots of criticisms including demonization of women of color (positioning them as "welfare queens"), for this study, we consider the aspects of the report that corroborate some of study participant's point of views. Recent research has found some justifications and validity in the report and even expanding on to other demographics (Masey et.al., 2009; Acs, et al., 2013). The issues highlighted in these reports include acute and concentrated poverty, unemployment, crimes, inequality in housing, in employment, education, health care, and the criminal justice system, high rate of non-marital birth and children raised in households headed by women and social welfare policies in Black communities. A revisited study by Urban Institute report and quoted by Acs et al. (2013) shows that the issues

... have only grown worse, not only for Blacks, but for Whites and Hispanics as well. Today, the share of White children born outside marriage is about the same as the share of Black children born outside marriage in Moynihan's day. The percentage of Black children born to unmarried mothers, in comparison, tripled between the early 1960s and 2009, remaining far higher than the percentage of White children born to unmarried mothers. (p.3)

Some, if not all, issues in the Moynihan Report are part of what participants reiterate in Westside community. The reason why these challenges linger is that the second part of the report 
that called for a national action has not been hearken to and prioritized. The failure of concerned institutions to instigate and affirm measures to curb the trend, has politicized the issue and made it a reference point for politicians who have continued to use the narratives to score political points, though not without criticisms (Lowery, 2014). Our study shows that the vicious cycle continued to fester across inner communities regardless of color, and until necessary measures are taken to curb the trend, marginalized communities will continue to be left behind.

With community problems of such magnitude, one important thing to consider is where is the best place to start. Residents of the study community have expressed their opinions in a specific way, but interestingly, there have been tremendous inputs from scholars, athletes and politicians on the subject matter. Their views are food for thought. For example, a public official has this to say about inner city culture as the cause of the blights in marginalized communities. His ideas in the following elaborate quote are a reflection of the reality of marginalized communities and inform the place to start helping struggling neighborhoods;

...I was not implicating the culture of one community - but of society as a whole. We have allowed our society to isolate or quarantine the poor rather than integrate people into our communities. The predictable result has been multi-generational poverty and little opportunity. I also believe the government's response has inadvertently created a poverty trap that builds barriers to work. A stable, good-paying job is the best bridge out of poverty. The broader point I was trying to make is that we cannot settle for this status quo and that government and families have to do more and rethink our approach to fighting poverty. I have witnessed amazing people fighting against great odds with impressive success in poor communities. We can learn so 
much from them, and that is where this conversation should begin. (Coppins,

The vital point to note in the quote is the clarion call on families and local authorities to arise and do something that will bring about positive change in Westside community. Another group to add to this recommendation are organizations and entities that work with or are in the community. Our study shows how these entities have been separated from one another, thus, the positive impact of their work is not felt in throughout the community. It is the strong recommendation of this research that for associations like Fairmont City Development Partnerships to prioritize the future well-being of residents and the community at large through the development of good working relationships and creation of employment and other opportunities for people from the community.

\subsection{Limitations}

The findings of this study reflect the experiences of residents of the Westside neighborhood of Fairmont and an analysis of W.O. Armstrong's manuscript as a secondary source of data. The 28 participants were selected using snowball and assertive methods, as stated in the methodology section. Many contacts were made during the Fostering Fairmont Project conducted by West Virginia University, and snowballed to churches, groups and individuals in the community. Based on the area of study, the 28 participants are judged to be a good representation of the neighborhood because they were well spread out in the neighborhood.

One limitation of this study is that it did not have access to Dunbar School records from Marion County School Board for additional views about the school. Meaning that, this study 
could be broadened to include the perceptions of the county school board members, teachers and administrators about the state of education in the Westside community.

The other limitation is that family relationships were not originally part of the study. We understand the important role family plays in community building; therefore, this area could also be explored in future studies. In all, insights gained from this research could inform development planning in other communities with similar experiences.

\subsection{Conclusions}

This study demonstrates the lasting impacts of history on the development prospects of a community. Without understanding the past, development efforts in a marginalized community may yield disappointing results. A community's history is about values, feelings, losses and successes, and opportunities for future generations. In the Westside community, in the wake of desegregation, relationship between this community and local governments have been strained and relationships among community members have been weakened, leading to stagnation and decline and rendering efforts to address issues ineffective.

Particularly great harm was done at the end of the desegregation era with the closing of Dunbar School, which was the social and cultural center of the community. It was the last straw that broke the camel's back and ended up destroying relationships and community spirit. Not only did the school closing take effective community leadership during a time of great change, but the learning culture and support of the community's children were disrupted and greatly diminished. Parents were no longer part of their children's learning community and qualified and mentors, teachers, administrators, counselors familiar with the community and its values and 
culture were asked to seek employment elsewhere. The qualities and qualifications of these individuals were never fully replaced.

Study participants believe that the worst thing that happened to the community was the forced departure of promising educational leaders, real freedom fighters, and generally people who passionately worked to bring about positive change, people who could have made a difference. After desegregation, potential well-educated leaders, many of them college graduates, left the community after finishing their education and never came back. Wallop's interview statements lean toward the perceptions of Garvey (1927) and Du Bois (1935), who predicted that the integration of Whites and Blacks would have negative consequences. Du Bois even wondered if separate schools were not better for both races.

The ripple effects of severed relationships are felt in the cultural, social, political, economic, educational, leadership and general well-being of the community. Although, desegregation was well intended, based on information gathered in this study and evidence available elsewhere, it did significant harm to several generations of Black students. Integration meant that Blacks from the Westside were transferred to Watson Elementary (Elizabeth, Interview, 2018). The only change experienced by White students was the sudden presence of a significant number of Black classmates; the burden of school integration was disproportionally born by African American communities. In addition, in practice, desegregation was mostly limited to public schools only and integration in the workplace and housing markets has still not been achieved.

However, the purpose of this study is not to argue against integration but highlight the effects of its implementation on the Westside community, which demoralized residents, kept them alienated from local governments, and negatively affected their sense of community and 
collective endeavors. These effects are demonstrated by the 71.42 percent of interview participants who expressed fear of change, lack of trust, suspicion, apathy, and a general lack of interest in and support for community development initiatives. These attitudes help explain the ambivalence and indifference vis-a-vis 612 MAC, FCYDC, Dunbar School Foundation, Fairmont City Development Partnerships and the Fostering Fairmont Project/Westside Action Coalition.

Changing the trajectory of the Westside community will require stakeholders to understand the past and its continuing effects. As Faulkner famously wrote: "The past is never dead. It's not even past." Only then can they develop mutually constructive relationships. Gaventa (1981) proposes principles of equal power relations because "a sense of powerless may manifest itself as extensive fatalism, self-deprecation, or undue apathy about one's situation..." Freire, (1973) similarly calls on individuals and groups to assertively act on their condition and achieve desired change. The continued failure of stakeholders to understand these principles is the major reason why the Westside remains stagnant and the community is disintegrating. The decline of Westside is of big concern to residents who nevertheless see a lot of good in their community and believe their neighborhood is not bad when compared to others like it around the country. As Diana (FG, 2018) notes:

There is a lot in our community, a lot more than you see it in these White communities, is a lot more with our children and I just sometimes... But you know, in reality, when you look at the statistics of those that are on welfare and the children that we deal with, we don't have too many Black kids. So, it's not that they're bad or that they're getting into trouble a lot, there are some that do. But I mean, I just think that I don't know, because we've just been so stigmatized that we just, we are accepting of the statistics of the things 
that they've placed on us. So, I don't know if we don't want to fight. There are a percentage of us that want to fight, that wants to change that, but then there's others that was just like, well you already said this about me, so I'll just keep going with it and not feel like.

There is a willingness and desire on the part of some residents to keep pushing for the revitalization of their community, but many feel that support is not forthcoming because:

If we invest it means that that lower class no longer is low. And where do we find ourselves in that? Are we now part of that? Do we want to be a part of that? I mean, these are all just huge, huge, huge, complicated questions, answers that we don't mean. So, when we really dive into it, do we really want to be, do we really want that? And I think unfortunately the core of our being, the answer is no. (Elizabeth, Interview, 2018)

Based on this research, the history of discrimination plays a significant role in the position taken by those with the responsibility of fostering the community and nurturing its development. This study shows the importance of understanding a community's history as expressed and perceived by its residents. The residents narratives should help inform the stakeholders in the neighborhood.

\subsection{Take away points of the study}

a. Westside residents and the neighborhood are lagging other communities in Fairmont. This is boosted by systemic racism that shaped decades-old policies that run the city. There has not been deliberate effort at any time to reframe or change those policies to reflect the new structural make-up of the city. What this suggests is that in past revitalization efforts by the city, organizations as well as community development 
practitioners did not factually understand the needs of the neighborhood and its residents before embarking on development initiatives.

b. The realities of Westside residents are affected by painful experiences of discrimination, marginalization and inequality. These have significant influence on their attitudes and approaches towards one another, leadership, the city, and potential experts coming into the community.

c. Along with the decline in coal employment, the fundamental values and culture of education of Westside residents shifted to unfamiliar territories. This creates a sense of forced apathy and withdrawal towards community activities. It extends further the communication gaps between families. Hence, it reinforces the reign of distrust and hopelessness as many residents lament the lack of resources and opportunities to build and grow.

d. Westside neighborhood has become reliant on help from external sources to re-build their community. There are also other problems such as education, social amenities, and non-committal attitude of city council members in responding to the neighborhood's problems as some residents have indicated, and most importantly the non-inclusion of members from the neighborhood in pertinent decision-making tables that concern their well-being.

Finally, this study paints a picture of a struggling neighborhood and residents left behind developmentally relative to other neighborhoods in the Fairmont. The residents perceive that support is not forthcoming, neither from within nor from outside the community. To improve on the present situation, attitudes, perceptions, and behaviors must be examined and some of them 
must be changed. From outside the community, the leaders of local governments and agencies must ensure equitable access to resources, share power to make decisions that affect the community, and help create a sense of common citizenship.

\subsection{Recommendations}

Understanding a community's struggles through its historical experiences provides firsthand knowledge of what shaped their values and attitudes and suggests pathways to developing a strategy along shared stories to shape approaches to community revitalization. Such an approach requires a robust participatory process. Issues affecting the well-being of the Westside community are sensitive, complicated, and are tied to historical discrimination and biases. According to our study, the Westside over the years has become a more diverse community, yet policies aimed at the neighborhood are not sensitive to its experiences nor its current social, economic, educational and leadership realities. Therefore, based on the findings of this study, we make the following recommendations:

- Policy must be responsive to the diverse and specific needs of the residents of the Westside neighborhood and pay attention to the effects of a history of discrimination, marginalization and stereotypes to overcome structural racism, inequality and deprivation.

- Policy must address and promote equity through educational opportunities as the focus of community revitalization and sustainable development. Afro-Centric or Black-led charter schools are options to consider. A charter school shaped by the values and aspirations of Black communities would recreate the lost connection between Blacks and the school that educates its youth. Such an initiative would require working with the 
Board of Education and other stakeholders. Even without the creation of such a charter school, recreating venues for Black parents to participate in and shape the education of their children must be pursued.

- Study participants, influenced by their experiences in the past until they present, do not believe that their interests are being represented by someone who understands, feels, and shares their concerns. Leadership and representation, therefore, should be reflective of the Westside residents and their realities, not on assumptions or speculations by individuals without ties to and knowledge of the neighborhood.

- Local authorities should develop and implement policies that generate trust by ensuring equitable access to resources and opportunities.

- Youth in the community face employment challenges that include lack of access to job opportunities and being ineligible for many good jobs because of a criminal record. Local authorities, and especially the City of Fairmont, should strive to support these youth and young adults, for example by reforming the manner in which information about job opportunities are disseminated and through programs to reintegrate those with criminal records.

- Residents should take pride in themselves, their property or rented homes, their community, and their history by coming together for community action. They must build trust in each other to succeed in contributing to the revitalization of their community. In addition, they should promote values and behaviors among their youth and young adults the reflect the attitudes and ambitions that Principal Armstrong had for his community. 


\subsection{A Path Forward}

Based on the findings of this study and as earlier highlighted in the literature, a possible theory of change for the Westside community evolves from the recommendations of Kubisch et al. (2013) and McKnight and Kretzman (1993). The former identified four building blocks that are quintessential to resident-centered community building: "create multiple ways for people to engage and contribute, build trust and capacity, communicate often and in many ways, and build the foundations for long-term work." They also provide guiding principles for supporters of resident-centered community building, such as developing relationships with residents, creating and supporting opportunities for residents to build ties, and fostering ways to combine external expertise and local knowledge. This was the core of the approach and method used during Fostering Fairmont Project. However, the success of this approach is hinged on the ability of residents to assume meaningful roles in taking charge of development initiatives.

To facilitate the process, McKnight and Kretzmann (1993) pose the following questions: "What can community members do best for themselves and each other? What can community members do best if they receive support from organizations? What can organizations do best for communities that people cannot do for themselves?"

These approaches show how to work towards building sustainable communities. The focus on building relationships between residents, government agencies, community development workers and other participants, addresses issues that often stymie community revitalization efforts. Professionals who do not have (or take) enough time to communicate with residents misinterpret behaviors of residents and blame them for failure of projects, rather than adverse economic and social structures or insufficient resources to address community needs. 
Being blamed for failure, residents feel slighted and ignored, which undermines support for future projects.

Therefore, the application of the theory of change in the Westside should start at the individual and family levels and continue to the community, associations/organizations, and local governments and agencies. The diminished sense of communitarianism towards more pronounced individualism and "survival of the fittest" influences attitudes and behaviors towards each other and makes building trust and sense of common purpose a greater challenge. However, according to study participants from the Westside community, they describe their community as tight, upbeat and interested in the welfare of others. This should provide a basis on which social and behavioral change activities can be built.

While residents seem to be optimistic about the strength of community spirit, they see that the role of the family in community building in the Westside as having been diminished. While Tammy (FG, 2018) attributes the weakening of the community to the crack epidemic, job losses in the declining coal industry and manufacturing, she cites the breakdown in the family as the primary cause of the problem. Although the family was not the focus of this study, participants like Tammy expressed their frustrations with men's unresponsiveness with regards to childcare and community advancement. The lost or reduced role of the family is an area for future study.

As shown in the literature review, African American communities are more functional as a group than individually or as families, even though community members see the family as the bedrock of a strong community. Participants were very proud to recapitulate assets (human, social, political, financial, cultural, natural and built capital) in their community as captured during the Fostering Fairmont Project. These critical assets must be revisited and deconstructed, 
using the popular Freirean method of "each one teach one." The phrase also reflects an important African American community value.

The need for the above approach is predicated on the data obtained for the study, which suggest that residents do not have primary understanding of how the assets work or are related. The vacuum created by the lack of proper knowledge and application of these assets must be filled to bridge relationship gaps between individuals, families, community, leaders, associations and organizations, local governments and agencies, and to leverage external assistance.

Emery and Flora (2006) classified community capital as shown in Figure 19 below. The interconnectedness of community assets and the position of human capital at the bottom, symbolizes its role in building, maintaining, managing and utilizing the other capitals. As the fulcrum on which other capitals revolve, human capital must be prioritized through planning, developing, nurturing and sustaining. When human capital is not made a priority or when it is disrupted as in the Westside neighborhood when segregation ended, the outcome is a struggling community, as expressed in the stories shared by the study participants.

Figure 19. Community Capitals - Emery \& Flora (2006).

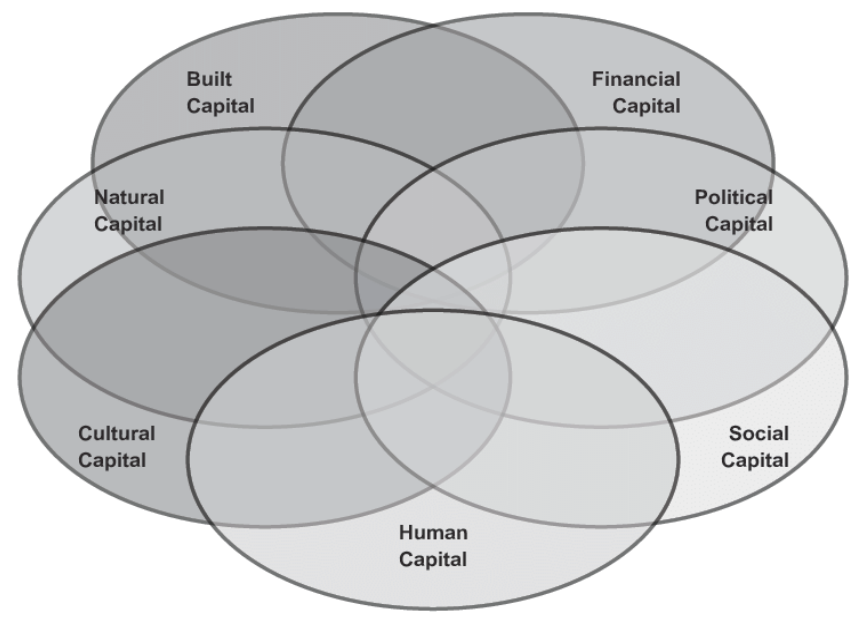


Organizations in the Westside community should also strive to understand their strategic roles in promoting the development of the community. This is not limited to creating and implementing good working relationships with and among stakeholders but should include support to assist development initiatives in the neighborhood. For example, churches could do more by going beyond their religious community and engage with other stakeholders in the community's future.

Other organizations, such as the Fairmont City Development Partnerships, need to do more to win the trust of residents. One way to achieve this could be by supporting youth and young adult development activities through cooperation with other associations like the FCYDC or Dunbar School Foundation. This would help remove fear and distrust in the motivations and activities of the organization.

Finally, the City of Fairmont has been at the center of criticism for doing less to support the Westside community than what it is doing in other Fairmont neighborhoods. The City could achieve more inclusive leadership by addressing real and perceived stereotypes and prejudices. This would require a sustained effort of communication with community residents and other stakeholders. The City should also review and improve its ways and methods of information dissemination and communication with the Westside community. This includes information about job opportunities, which at present are perceived as less accessible to Westside community members than city residents elsewhere. Also, showing an interest in helping and supporting the neighborhood's youth and young adults would help restore trust between the neighborhood and the City. 


\section{References}

A brief History of African Americans in West Virginia. (2018). Retrieved January 01, 2019, from http://www.wvculture.org/history/archives/blacks/blachist.html

Acs, G., Braswell, K., Sorensen, E., \& Turner, M. (2013). The Moynihan Report Revisited. https://www.urban.org/sites/default/files/publication/23696/412839-The-MoynihanReport-Revisited.PDF

Andrews, P. (2017, December 07). African American Leadership Development Matters in the New Age. Retrieved February 16, 2019, from https://www.huffingtonpost.com/philandrews/african-american-leadersh_b_9765120.html

Anglin, Roland V. (2011). Promoting Sustainable Local and Community Economic Development. Boca Raton, FL: CRC Press. (ISBN 9781420088106)

Armstrong, W. O. (n.d.). W.O. Armstrong Manuscripts. Unpublished manuscript, 1, West Virginia University Historical Library.

Arnstein, S. R. (1969). A Ladder of Citizen Participation. Journal of the American Institute of Planners, 35(4), 216-224. https://doi.org/10.1080/01944366908977225

Autti, O., and Hyry-Beihammer, E. K. (2014). School closures in rural Finnish communities. Journal of Research in Rural Education, 29(1), 1-17. Retrieved from http://jrre.psu.edu/articles/29-1.pdf

Barbaro, G. 2006. Defining realities: Why community consultation needs to start with the problem, not the solution. Journal of Communication Management, 10(1): 44-55. 
Beckmann, S. (2012). "American Aid to Greece: The Marshall Plan as a Model for Development $\begin{array}{llll}\text { Aid." Clocks } \quad \text { and } & \text { Clouds, 1(1). }\end{array}$ from http://www.inquiriesjournal.com/a?id=1619

Bell, D. A. (2006). Silent covenants: Brown v. Board of Education and the unfulfilled hopes for racial reform. Oxford: Oxford University Press.

Bellah, R. N., Madson, R., Sullivan, W. M., Swindler, A., and Tipton, S. M. (1985). Habits of the heart. Berkeley: University of California Press.

Bennis, W. (2003), Leaders: Strategies for Taking Charge, HarperCollins Publishers, New York, NY, p. 78

Bergdall, T. (2012). Facilitating asset-based community development. In T. Timsina and D. Neupane (Eds.), Changing lives, changing society: ICA'S experience in Nepal and in the World. Kathmandu: The Institute of Cultural Affairs. Available from https://resources.depaul.edu/abcd-institute/publications/publications-bytopic/Documents/Bergdall\%20-

\%20Reflections $\% 20 \mathrm{on} \% 20$ the $\% 20$ Catalytic\%20Role\%20of\%20an\%20Outsider\%20in \%20ABCD.pdf

Bois, W. E. (1935). Does the Negro need Separate Schools? The Journal of Negro Education, 4(3), 328. doi:10.2307/2291871

Bonilla-Silva, E. (2015, November 12). The White Racial Innocence Game -. Retrieved December 30, 2018, from http://www.racismreview.com/blog/2015/11/12/white-racialinnocence-game/ 
Boone, E. J., Safrit, R. D., and Jones, J. (2002). Developing programs in adult education: a conceptual programming model. Prospect Heights, IL: Waveland Press.

Breen, R. L. (2006). A practical guide to focus-group research. Journal of Geography in Higher Education, 30(3), 463-475. Doi: 10.1080/03098260600927575

Brenman, M., \& Sanchez, T. W. (2012). Planning as if people matter: Governing for social equity. Washington, DC: Island Press.

Brinkmann, S., and Kvale, S., (2015). Interviews: Learning the craft of qualitative research interviews. Thousand oaks, California: Sage publications.

Bryant, J. (2016, September 09). The Racism of School Closures. Retrieved August 14, 2018, from https://progressive.org/public-school-shakedown/racism-school-closures/

Bump, P. (2014, April 01). The Source of Black Poverty Isn't Black Culture, It's American $\begin{array}{lllll}\text { Culture. } & \text { Retrieved } & \text { February } & 21, & \text { 2019, }\end{array}$ https://www.theatlantic.com/politics/archive/2014/04/the-source-of-black-poverty-isntblack-culture-its-american-culture/359937/

Bunyan, P. (2012). Partnership, the Big Society and community organizing between romanticizing, problematizing and politicizing community. Community Development Journal,48(1), 119-133. doi:10.1093/cdj/bss014

Buras, K. L. (2014). Charter schools, race, and urban space: Where the market meets grassroots resistance. New York: Routledge.

Butchart, R. E. (1986). Local schools: exploring their history. Nashville: American Association for State and Local History. 
Cammarota, J. (2011). From hopelessness to hope: Social justice pedagogy in urban education and youth development. Urban Education, 46, 828-844.10.1177/0042085911399931

Carmichael, S., \& Hamilton, C. V. (1967). Black Power: The Politics of Liberation in America. Racism: Essential Readings, 111-121. doi:10.4135/9781446220986.n11

Chaskin, Robert J., Prudence Brown, Sudhir Venkatesh, Avis Vidal (2001). Building Community Capacity. New York: Aldine de Gruyter. (ISBN 9780202306407)

Coetzee, K. J., Graaf, J., Heindricks, F. and Wood, G. (2007). Development: Theory, Policy and Practice. Cape Town: Oxford University Press.

Cohen, L., Manion, L., and Morrison, K. (2011). Research methods in education (7th ed.). Abingdon, Oxon, NY: Routledge.

Cohen, R. M. (n.d.). School Closures: A blunt Instrument. Retrieved November 30, 2017, from http://prospect.org/article/school-closures-blunt-instrument-0

Cola, L. (2017, July 04). How Vast Amounts Of Land Have Been Stolen From Black Americans. Retrieved February 2, 2019, from https://www.mintpressnews.com/vast-amounts-land-stolenblack-americans/229427/

Collins, D. E. (1977). Paulo Freire: His life, works, and thought. New York: Paulist Press.

Conrad, C. (2005). African Americans in the U.S. economy. Lanham, MD: Rowman \& Littlefield.

Copeland, R. (2013). In the Beginning: Origins of African American Real Property Ownership in the United States. Journal of Black Studies, 44(6), 646-664. Retrieved from http://www.jstor.org/stable/24572860 
Coppins, M. (2014, March 13). Paul Ryan Says His Controversial Comments About Inner-City Poor Were "Inarticulate". Retrieved February 25, 2019, from https://www.buzzfeednews.com/article/mckaycoppins/paul-ryan-says-his-controversialcomments-about-inner-city-p

Creswell, J. W. (2009). Research design: Qualitative, quantitative and mixed methods approaches (3rd ed.). London, UK: Sage.

Crook, C. (2001, September 29). Globalization and its critics. Retrieved January 25, 2018, from http://www.economist.com/node/795995

Crotty, M. (1998). The foundations of social research: Meaning and perspective in the research process. Thousand Oaks, CA: SAGE.

Crotty, M. (2012). The foundations of social research meaning and perspective in the research process. London: SAGE.

Dale, A., \& Newman, L. (2008). Social capital: a necessary and sufficient condition for sustainable community development? Community Development Journal, 45(1), 5-21. https://doi.org/10.1093/cdj/bsn028

Davis, C. (2015, May 8). The critique of critical theory, The Global Center for Advanced Studies. Retrieved October 1, 2017 from globalcenterforadvancedstudies.org/the-critique-ofcritical-theory/.

Delgado, M., and Staples, L. (2007). Participatory democracy. Youth-led community organizing, 95-110. doi:10.1093/acprof:oso/9780195182767.003.0005 
Delgado, M. (2002). New frontiers for youth development in the twenty-first century: Revitalizing and broadening youth development. New York, NY: Columbia University Press.

Denzin, N. K. (1986). Interpretive biography. Newbury Park, CA, Sage.

development policy. Public Administration, 87(1), 65-79. doi:10.1111/j.14679299.2008.01742.x

Diaz, P. (2017, November 24). The End of Poverty. Retrieved February 21, 2019, from https://www.youtube.com/watch?v=DrRiU2nuDpU

Dreyer, W. (2015). The real crisis of the church. Hervormde Teologiese Studies, 71(3), 1-5. Retrieved from https://search.proquest.com/docview/1738751291?accountid=2837

Du Bois, W. E. B. (1903). The Souls of Black Folk. New York: Dover Publications.

Dwyer, S. C., \& Buckle, J. L. (2009). The Space Between: On Being an Insider-Outsider in Qualitative Research. International Journal of Qualitative Methods, 5463. https://doi.org/10.1177/160940690900800105

Editors, H. (2010, January 27). Fair Housing Act. Retrieved February 13, 2019, from https://www.history.com/topics/black-history/fair-housing-act

Education. Columbus: Ohio State University.

Egelund, N., and Laustsen, H. (2006). School closure: what are the consequences for the local society? Scandinavian Journal of Educational Research, 50(4), 429-439. doi:10.1080/00313830600823787

Eisenberg, A. M. (2016). Addressing Rural Blight: Lessons from West Virginia and WV LEAP, 24, Journal of Affordable Housing and Community Development Law 513. 
Explore Watson Elementary School in Fairmont, WV. (n.d.). Retrieved November 23, 2019, fromhttps://www.greatschools.org/west-virginia/fairmont/429-Watson-ElementarySchool/.

Ellwood, D. "The Marshall Plan: A Strategy That Worked - Library." Www.Marshallfoundation.Org,1Apr.2006, www.marshallfoundation.org/library/documents/marshall-plan-strategy-worked/. Accessed 11 Apr. 2020.

Emery, M., \& Flora, C. (2006). Spiraling-Up: Mapping Community Transformation with Community Capitals Framework. Community Development,37(1), 19-35. https://doi.org/10.1080/15575330609490152

Farmer, B. H. (1986). Perspectives on the Green Revolution in South Asia. Modern Asian Studies. 20 (01): 175-199. oii:10.1017/s0026749x00013627.

Ferguson, M. (1995). Media Markets and Identities: Reflections on the Global-Local Dialectic. Canadian Journal of Communication, 20 (4): 11-33, Open Journal System, www.cjc.online.ca/viewarticle.phpid.=313andlayout.html.

Fiske, S. T. (2010). Interpersonal Stratification: Status, Power, and Subordination. Handbook of Social Psychology. doi:10.1002/9780470561119.socpsy002026

Flora, Cornelia, and Jan L. Flora. 2007. Rural Communities: Legacy and Change. 3rd ed. Boulder, CO: Westview Press.

Freire, P., Freire, A. M., and Freire, P. (2014). Pedagogy of hope: Reliving pedagogy of the oppressed. London: Bloomsbury. 
Fritz, J. (1989). The history of clinical sociology. Pp.72-95 in J. Fritz and E. Clark, VII, eds., Sociological Practice. East Lansing: Michigan State University Press.

Furman, G. C. (2002). School as community: From promise to practice. Albany: State University of New York Press.

Galletta, A., and Ayala, J. (2008). Erasure and survival: Creating a future and managing a past in a restructuring high school. Teachers College Record, 110(9), 1959-1983.

Garner, S. (2010). Racisms: An introduction. London: SAGE.

Giddens A 1995. Modernity and Self-Identity: Self and Society in the Late Modern Age. UK: Cambridge Press.

GradeSaver "The Wretched of the Earth Themes". GradeSaver, 6 November 2017. Web. 6 November 2017.

Greenbaum, T. L. (2000). Moderating focus groups: a practical guide for group facilitation. Thousand Oaks, CA: Sage Publications.

Gross, T. (2017, May 3). A “Forgotten History” Of How The U.S. Government Segregated America. NPR.Org. https://www.npr.org/2017/05/03/526655831/a-forgotten-history-ofhow-the-u-s-government-segregated-america

Gutman, D. (2017, October 27). West Virginia has a complicated history with race and civil rights. Retrieved January 02, 2019, from https://www.wvgazettemail.com/news/westvirginia-has-a-complicated-history-with-race-and-civil/article_4805cb60-d947-5946ab37-8f2e7f410fb3.html

Hanks, A., Solomon, D., \& Weller, C. E. (2018, February 21). Systematic Inequality. Retrieved February 13,2019 ,from 
https://www.americanprogress.org/issues/race/reports/2018/02/21/447051/systematic-

inequality/

History of Enterprise. (n.d.). Retrieved September 09, 2018, from https://www.enterpriseal.gov/history-of-enterprise

Hodgett, S. and Deneulin, S. (2009), On the use of Narratives for Assessing Development Policy. Public Administration, 87: 65-79. doi:10.1111/j.1467-9299.2008.01742.x

Horkheimer, M. (1976). Traditional and critical theory. In. Connerton (Ed.), Critical sociology: Selected readings. New York: Penguin.

Horkheimer, M. (2002). Critical theory: selected essays. New York: Continuum.

Hynes, Gerald (2002). A biographical sketch of W.E.B. DuBois. Retrieved on October 6, 2006: http://www.duboislc.org/html/DuBoisBio.html.

Ife, J. W. (2013). Community development in an uncertain world: Vision, analysis and practice. Cambridge: Cambridge University Press.

Illich, I. (2012). Deschooling Society. London: Marion Boyars.

Irvine, R., \& Irvine, J. (1984). The impact of the desegregation process on the education of black students: Key variables, Journal of Negro Education, 52, 410-422.

J. C. (n.d.). (PDF) Understanding Community Development - ResearchGate. Retrieved January $10,2019,2019$, from https://www.researchgate.net/publication/265233282_Understanding_Community_Dev elopment

J. L. (2016, April 18). Effective Community Development. Retrieved December 19, 2018, from https://shelterforce.org/1994/07/01/effective-community-development/ 
Jackson, M.C. (1985). Social systems theory and practice: The need for a critical approach. International Journal of General Systems, 10(2), 135-151.

Jackson-Lowman, H. (2013). An analysis of the impact of Eurocentric concepts of beauty on the lives of African American women. In H. Jackson-Lowman (Ed.) African American women: Living at the crossroads of race, gender, class, and culture (pp.155-172). San Diego, CA: Cognella Academic Publishing

James, W. (2017). Personal Communications.

Jimu, I. M. (2016). Moving in circles: underdevelopment and the narrative of uncertainty in the global periphery. Mankon, Bamenda: Langaa Research and Publishing Common Initiative Group.

Johnston, K. A. (2010). Community Engagement: Exploring a Relational Approach to Consultation and Collaborative Practice in Australia. Journal of Promotion Management, 16(1-2), 217-234. doi:10.1080/10496490903578550

Kaufman, H. F. (1959). Toward an interactional conception of community." Social Forces 38 (0ctober):8-17.

Kilson, Martin (2000). The Washington and Du Bois Leadership Paradigms Reconsidered. Annals of the American Academy of Political and Social Science, 568, 298-313.

Kim, Y. (2011). The Pilot Study in Qualitative Inquiry: Identifying Issues and Learning Lessons for Culturally Competent Research. Qualitative Social Work, 10(2), 190206. https://doi.org/10.1177/1473325010362001

Kimbrough, W., \& Hutcheson, P. (1998). The Impact of Membership in Black Greek-Letter Organizations on Black Students' Involvement in Collegiate Activities and Their Development of Leadership Skills. The Journal of Negro Education, 67, 96-115. 
Kirshner B., and Pozzoboni K. M., (2011). Student interpretation of a school closure: implications for student voice in equity-based school reform. Teachers College Record, 113(8), 1633- 1667.

Kissinger, H. A. (2015, May 22). Reflections on the Marshall Plan. Retrieved February 04, 2018, from https://news.harvard.edu/gazette/story/2015/05/reflections-on-the-marshall-plan/

Koon, Thomas J. "Fairmont." e-WV: The West Virginia Encyclopedia. 30 May 2013. Web. 19 December 2017.

Kouzes, J. M., \& Posner, B. Z. (1987). The Leadership challenges. San Francisco: Jossey-Bass.

Kral, R. (1989). Strategies that work: Techniques for solutions in the schools. Milwaukee, WI: Brieg Family Therapy Center.

Kretzmann, J. P., and McKnight, J. L. (1993). Building communities from the inside out: a path toward finding and mobilizing a community's assets. Evanston, Ill.: Center for Urban Affairs and Policy Research, Northwestern University. Introduction available from http://www.abcdinstitute.org/publications/basicmanual/

Krieger, J., \& Higgins, D. L. (2002). Housing and Health: Time Again for Public Health Action. American Journal of Public Health, 92(5), 758-768. doi:10.2105/ajph.92.5.758

Krueger, R. A. (2002, October). Designing and Conducting Focus Group Interviews. Retrieved $\begin{array}{lll}\text { March 2, 2018, from } & \text { 2, }\end{array}$ http://www.bing.com/cr?IG=0AE3ED4F44C44F33AC41E1D68E735110\&CID=07397 23FE33868DC27F07999E2976947\&rd=1\&h=N4UrUIEetMX4r7NbgxYE5sC4sUUPumqyf6YbojOfe $8 \& v=1 \& r=h t t p \% 3 a \% 2 f \% 2$ fwww.eiu.edu $\% 2$ fihec $\% 2$ fKrueger$\underline{\text { FocusGroupInterviews.pdf\&p=DevEx,5064.1 }}$ 
Kruse, K. M. (2019, August 14). How Segregation Caused Your Traffic Jam. Retrieved December 14,2019 , from https://www.nytimes.com/interactive/2019/08/14/magazine/traffic-atlantasegregation.html.

Langone, C. A. (1992). Building Community Leadership. Retrieved February 21, 2019, from https://joe.org/joe/1992winter/a7.php Journal of Extension

Leonardo, Z. (2009). Race, whiteness, and education. New York, NY: Routledge.

Lewan, T., \& Press, D. B. (2001, December 02). 'When They Steal Your Land, They Steal Your Future'. Retrieved February 2, 2019, from http://articles.latimes.com/2001/dec/02/news/mn-10514

Lowery, W. (2014, March 18). Paul Ryan, poverty, dog whistles, and electoral politics. Retrieved February 24, 2019, from https://www.washingtonpost.com/news/the-fix/wp/2014/03/18/paulryan-poverty-dog-whistles-and-racism/?utm_term=.a1db9cf59ee5

Litosseliti, L. (2003). Using focus groups in research. London: Continuum International Publishing Group - Academic and Professional.

Lyles, M. (2013). Segregation to Desegregation: The Journey of African American Students to Academic Excellence or Academic Despair. (A Doctoral Dissertation, University of Washington). Available from ProQuest Dissertations and Theses database (UMI Number: 3588779).

Manero, E. (2017, February 3). China's Investment in Africa: The New Colonialism? Harvard Political Review Retrieved February 04, 2018, from http://harvardpolitics.com/world/chinas-investmentin-africa-the-new-colonialism/ 
Markova, I. (1997). The individual and the community: A post-Communist perspective. Journal of Community and Applied Psychology, 7, 3-17.

Marshall, G. C. (1947, June 5). Bipartisan Foreign Policy: The Marshall Plan. Retrieved February 21, 2019, from https://www.archives.gov/exhibits/treasures_of_congress/text/page22_text.html Martin Luther King Jr.'s inspirational quotes that resonate today. (2018, January 09). Retrieved February 21, 2019, from http://www.nydailynews.com/news/martin-luther-king-jr-sinspirational-quotes- resonate-today-gallery-1.2206693?pm Slide $=1.2206690$

Massey, D. S. (2015). The Legacy of the 1968 Fair Housing Act. Sociological Forum (Randolph, N.J.), 30(Suppl 1), 571-588. http://doi.org/10.1111/socf.12178

Massey, D. S., Sampson, R. J., \& Kaniss, P. C. (2009). The Moynihan Report revisited: Lessons and reflections after four decades. Thousand Oaks, CA: SAGE Publications.

Mathew, S. A. (2016). Resistance, agency and violence: Dalit women's education in Kerala, India. (Doctoral Dissertation, West Virginia University). College of Education and Human Services: Available from ProQuest Dissertations and Theses database.

Matthew, C., \& Jeffrey, D. S. (n.d.). Sociology of Racism - Scholars at Harvard. Retrieved January 16, 2019, $\quad$ from https://scholar.harvard.edu/files/matthewclair/files/sociology of racism clairandenis 2015.pdf

Matunhu, J. (2014, January 03). A Critique of modernization and dependency theories in Africa: Critical assessment. Retrieved January 25, 2018, from https://kiestikoisme.wordpress.com/2014/01/03/acritique-of-modernization-and-dependency-theories-in-africa-critical-assessment/

Maxwell, J. C. (1999). The 21 indispensable qualities of a leader. Nashville: Thomas 
Maxwell, J. C. (2007). The 21 irrefutable laws of leadership: Follow them and people will follow you. Nashville, TN: HarperCollins Leadership.

McCullen, L. (n.d.). The Role of the Church in the Civil Rights Movement. Retrieved February 08, 2018, from Senator Sam Earvin the 1964 Civil Rights Act.http://ervin062.web.unc.edu/reactions-tocivil-rights/using-religion-to-pose-and-defend-an-argument/

McMickle, M. A. (n.d.). "The Black Church," a brief history. Retrieved January 03, 2018, from http://www.aaregistry.org/historic_events/view/black-church-brief-history

Miles, M. B., Huberman, A. M., \& Saldaña, J. (2014). Qualitative data analysis: A methods sourcebook. Thousand Oaks, California: SAGE Publications.

Miller, D. L. (1967). Individualism. Austin, TX and London: University of Texas Press.

Miller, M. A. (1990). Exploring rural community readiness for participation in community and natural resource development extension education programs, Agricultural

Miller, M. M. (2016, January 22). Poverty Inc. Retrieved February 21, 2019, from https://www.youtube.com/watch?v=yPmawWgpX0s

Mintz, S. (2007). African American Voices. Retrieved February 20, 2019, from http://www.digitalhistory.uh.edu/black_voices/voices_display.cfm?id=23

Molotch, H. (1976). The City as a Growth Machine: Toward a Political Economy of Place. Cities and Society, 15-27. doi: 10.1002/9780470752814.ch2

Moynihan, D. P. (2018). The Moynihan report: The negro family--the case for national action. New York: Cosimo Reports. 
Moon, F. F. (2009, January). The Role of the Church in the Civil Rights Movement. Retrieved February 08, 2018, from http://ervin062.web.unc.edu/reactions-to-civilrights/using- religion-to-pose-and- defend-an-argument/ Nelson Publishers.

Native American - Removal from their Land - Immigration...- Classroom Presentation |Teacher Resources. (February 19). Retrieved February 19, 2019, from http://www.loc.gov/teachers/classroommaterials/presentationsandactivities/presentation s/immigration/native_american2.html.

NCES, (2019, February). Indicator 6: Elementary and Secondary Enrollment. Retrieved February 24, 2019, from https://nces.ed.gov/programs/raceindicators/indicator_RBB.asp

NCES, (2019, February). Indicator 5: Early Childcare and Education Arrangements. Retrieved February 24, 2019, from https://nces.ed.gov/programs/raceindicators/indicator_RBA.asp

NCES, (2019, February). Indicator 29: Youth and Young Adults Neither Enrolled in School nor

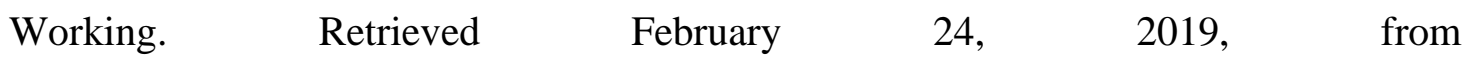
https://nces.ed.gov/programs/raceindicators/indicator_RFC.asp

Newing, H. (2010). Conducting research in conservation: A social science perspective. Abingdon, Oxon, UK: Routledge.

Neuman, W. L. (1994). Social Research Methods: Qualitative and quantitative approaches.

Nickels, A. E. (2017). White flight/black flight: The dynamics of racial change in an American neighborhood. Community Development, DOI: 10.1080/15575330.2017.1400200

Nisbet, R. A. (1962). Community and Power. New York: Oxford University Press. 
Oberhauser, A. M. (1997). "The Home as 'Field': Households and Homework in Rural Appalachia," in J.P. Jones III, H. J. Nast, and S. M. Roberts (eds.) Thresholds in Feminist Research: Difference, Methodology, and Representation, pp. 165-183. New York: Rowman and Littlefield

Osokoya, O.I. (1987). 6-3-3-4 education in Nigeria: history, strategies, issues and problems, Lagos: Bininaike Educational Publishers.

Palmiste, C. (2008). 'Forcible Removals: The case of Australian Aboriginal and Native American Children', Alternative 4, 76-88.

Panuska, M. (2014, July 27). City taking over site of former black Elks. Retrieved July 30, 2019, from $\quad \underline{\text { https://www.timeswv.com/news/local_news/city-taking-over-site-of-former- }}$ black-elks/article_96dce9c0-bf7f-57aa-8215-cf8513aa2e98.html

Perkins, D. G. (1995). Empowerment theory, research, and application. Journal of Community Psychology, 23(5), $569-579$

Pickens, W. (1927, December). Opportunity: Journal of Negro Life. Retrieved January 6, 2019, from http://nationalhumanitiescenter.org/pds/maai3/segregation/text1/racialsegregation.pdf

Presthus, R. (1964). Men at the Top: A Study in Community Power. York: Oxford University Press.

PSR, (2019). West Virginia Private Schools by Tuition Cost. Retrieved February 26, 2019, from https://www.privateschoolreview.com/tuition-stats/west-virginia

Putnam, R. D. (1996). Bowling alone: Americas declining social capital. Ottawa, On: Centre canadien de gestion. 
Ramey, H. L., Busseri, M. A., Khanna, N., and Rose-Krasnor, L. (2010). Youth engagement and suicide risk: Testing a mediated model in a Canadian community sample. Journal of Youth and Adolescence, 39, 243-258.

Randall, V. (2004) "Using and Abusing the Concept of the Third World: Geopolitics and the Comparative Political Study of Development and Underdevelopment," Third World Quarterly, 25:1, pp. 41-53.

Reid, D. (1995). Sustainable Development: An Introductory Guide. London: Earthscan Publications Ltd.

Retrieved from http://www.joe.org/joe/1992winter/a7.php

Robinson, J. (2004). Squaring the circle? Some thoughts on the idea of sustainable development. EcologicalEconomics, 48(4),369-384. https://doi.org/10.1016/j.ecolecon.2003.10.017

Rochon, T. R. (2015, November 16). Why Embattled Leaders Should Be Stepping Up, Not Stepping Down. Retrieved December 30, 2018, from https://www.chronicle.com/article/Why-Embattled-Leaders-Should/234222

Rodney, W. (1972). How Europe Underdeveloped Africa. Dar es Salaam: Tanzanian Publishing House.

Roozen, D. A. (2011, September 17). American Congregations - Faith Communities Today. Retrieved February 15, 2019, from http://faithcommunitiestoday.org/sites/default/files/Decade of Change Final_0.pdf

Roozen, D. A. (2016). American Congregations - Faith Communities Today. Retrieved February 15, 2019, from 
Rosero, L. D., \& Erten, B. (2010). Delinking through Integration: A Dependency Analysis of Regional Financial Integration. Critical Sociology, 36(2), 221242. https://doi.org/10.1177/0896920509343083

Rosser, C. (1955). Bulletin of the School of Oriental and African Studies, University of London, 17(1), 181. Retrieved from http://www.jstor.org/stable/609246

Ryan, F., Coughlan, M., and Cronin, P. (2009). Interviewing in qualitative research: the one-onone interview. International Journal of Therapy and Rehabilitation, 16(6), 309 -314.

Ryan, J. E. (1999). Schools, race, and money. The Yale Law Journal, 109(2), 249-316. Retrieved from http://www.libproxy.wvu.edu/login?url=https://search.proquest.com/docview/1984633 75 ?acc ountid $=2837$

Sanders, G.F. and Grandbois, D.M. (2009). The Resilience of Native American Elders, Issues in Mental Health Nursing 30, 569-580.

Schram, T. H. (2006). Conceptualizing and proposing qualitative research, 2nd ed. Upper Saddle River, NJ: Pearson Education, Inc.

Schumacher, E. F., \& McKibben, B. (2014). Small is beautiful: Economics as if people mattered. New York, NY: Harper Perennial.

Shaffer, R., Deller, S., and Marcouiller, D. (2006). Rethinking Community Economic Development. Economic Development Quarterly, 20(1), 59-74. doi:10.1177/0891242405283106

Sherraden, M. (1991). Assets and the poor: A new American welfare policy. Armonk, NY: M. E. Sharpe, Inc. 
Sikes, P. (2004). Methodology, procedures and ethical concerns: Doing educational research a guide for first time researchers. London: Sage.

Soaries, R. D. (2010, August 01). Black churches and the role of empowerment. Retrieved February 08, 2018, from http://www.cnn.com/2010/OPINION/08/01/soaries.black.church/index.html social equity. Washington: Island Press.

Spring, J. (2005). Conflict of Interests: The Politics of American Education. New York, New York: McGraw-Hill

Spring, J. H. (2010). Political agendas for education: from change we can believe in to putting America first. New York: Routledge.

Stack, S. F. (2015). The Arthurdale Community School: education and reform in Depressionera Appalachia. Lexington: University Press of Kentucky.

Stiglitz, J. E. (2002). Globalization and Its Discontents (London and New York: W.W. Norton)

Strauss, A., and Corbin, J. (1998). Basics of qualitative research: Grounded theory procedures

Sultana, F. (2007). Reflexivity, positionality and participatory ethics; negotiating fieldwork dilemmas in international research. ACME, 6(3), 374-385.

Tausch, A. (2010) "Globalization and development: the relevance of classical "dependency" theory for $\quad$ the world today," International Social Science Journal, 61:202, pp. 467488

Theodorson, G. A. and Theodorson, A. G. (1969). A Modern Dictionary of Sociology. New York: Barnes and Noble Books. 
Tunstall, B. (2012, June 06). Is there a proven link between housing and happiness? Retrieved March 05, 2018, from $\quad$ https://www.theguardian.com/housingnetwork/2012/jun/06/link-between-housing- and-happiness

Valencia, R. R. (2008). Chicano students and the courts: The Mexican American legal struggle for educational equality. New York: New York University Press.

Walker, \& Archung. (2003). The Segregated Schooling of Blacks in the Southern United States and South Africa. Comparative Education Review, 47(1), 21. doi:10.2307/3542065

Walker, V. (1996). Their highest potential: An African American school community in the segregated south. Chapel Hill: University of North Carolina Press.

Walton, J. (1968). Differential patterns of community structure; An explanation based on interdependence. The Sociological Quarterly 9; 11-12.

Warren, R. L. (1978). The Community in America. Third edition. Chicago: Rand McNally.

War by Bob Marley with lyrics [Advertisement]. (2012, June 25). Retrieved March 02, 2019, from https://www.youtube.com/watch?v=1Hrglx9PCpo

Wellington, J.A., et al. (2005). Succeeding with your doctorate. London, Sage.

Wenger, M. (2006). Rising African American Leaders: Challenges for a New Generation. $\begin{array}{llll}\text { Retrieved } & \text { February } & 16, & \text { 2019, }\end{array}$ http://www.racialequitytools.org/resourcefiles/wenger.pdf

Wilkinson, K. P. (1979). Social well-being and community. Journal of the Community Development Society 10 (spring):5-16. 
Winder, A. E. (2003). Book Review: Building Communities from the inside Out: A Path toward Finding and Mobilizing a Community’s Assets by Kretzmann J. P. and McKnight John L., Chicago, Illinois: ACTA Publications, pp.376 International Quarterly of Community Health Education, 22(3), 229-231. doi:10.2190/pd41-gkww-ru7x-m7y4 www.faithcommunitiestoday.org/sites/default/files/American-Congregations2015 0.pdf

Yinger, J. (1997). Closed doors, opportunities lost: The continuing costs of housing discrimination. New York: Russell Sage Foundation.

Yu, J. (2009, January). Kill the Indian, Save the Man. Retrieved February 20, 2019, from https://pabook.libraries.psu.edu/literary-cultural-heritage-map-pa/feature-articles/killindian-save-man 


\section{Appendix A}

\section{Interview protocol}

Advisor: Dr. Peter Schaeffer

Student Researcher: Christopher Agba

Topic: Developing marginalized and segregated community: Case study of A west Virginia Neighborhood.

Time of Interview/ Focus group discussion:

Participant Selection: This interview is scheduled for three categories of Westside residents, who were also students at Dunbar School between three generations of Dunbar School. Their respective experiences through the segregation and desegregation eras will provide useful information for this study. A couple of White residents are also considered for this interview. These two lived in the neighborhood during and after segregation and are good friends with Dunbar School attendees. I believe that their perspectives on the neighborhood will form a sort of interesting comparison for the study, besides being a viable source of data generation. The location for the interview will be at the participants' homes, for comfort, confidentiality and mobility/transportation reasons.

Three central locations are considered for the focus group discussion. There is The Dunbar School Annex, the Youth Center and a Church building within the neighborhood. Refreshment will be provided during these sessions.

Thank you for your participation in this WVU IRB approved research. This interview should take approximately xx minutes, depending on how long we talk. I would like to audio record the interview to enable me to have an accurate understanding of our conversation. Kindly let me know at any point if you do not want to be recorded or would like to stop the research. What questions do you have before we begin?

Semi-structured interview questions

Understanding the historical and current context of Westside neighborhood and community involvement

* Tell me the story of the Westside neighborhood. When did the story begin for you? What were the particular high and low points over the years?

* What are the greatest assets of this neighborhood? What are the legacies from the past that remain in Westside today?

* Compare Westside neighborhood now and 25 years ago. What can you say are the problems and needs of this community today?

* What role has the church played in the neighborhood in the past? In the present? 
* What are the values in Westside neighborhood? Are they similar to the values of the larger community of Fairmont? How do they differ? Why?

* How do people in your neighborhood communicate?

* Who are the leaders in the neighborhood? Who recognizes them as leaders? Anyone else?

* What can you say about the attitude and relationship between the City Council and the neighborhood?

* Can you think of a time when there were unequal power dynamics affecting the neighborhood? What happened? How did this affect you? The neighborhood?

* What are some of the problems that the youth face in this community?

* What are your thoughts about the future of the Westside?

* During what years did you attend Dunbar School? What was your schooling like after that point?

* When you think about Dunbar School, what comes to your mind?

* What role did Dunbar play in this neighborhood?

* What kind of relationship did you have with your teachers during the segregated era?

* How did you see yourself as a student at the segregated school?

* What was the desegregated school like?

* How did you see yourself as a student at the desegregated school?

* What is your take on social, economic and cultural life in the neighborhood?

* What do you think about community development efforts in the neighborhood?

* Do you have any additional comments that would help me understand this conversation?

Thank you 
Interview cover letter:

September 28, 2017

Dear Participants,

This letter is a request for you to take part in a research project to gather information about the development of marginalized and segregated rural communities in West Virginia. This project is being conducted by Christopher Agba, Ph. D., candidate in the Department Design and Community Development at West Virginia University. Your participation in this project is greatly appreciated and will take approximately 1.5 to 2 -hour minutes to complete. There is a telephone or in-person interview in which I record your responses.

Your involvement in this project will be kept as confidential as legally possible. You must be 18 years of age or older to participate. Your participation is completely voluntary. You may skip any question that you do not wish to answer, and you may discontinue at any time. West Virginia University's Institutional Review Board approval of this project is on file.

I hope that you will participate in this research project, as it could be beneficial in understanding and development of ideas that could develop community driven projects. Thank you very much for your time. Should you have any questions about this letter or the research project, please feel free to contact Christopher Agba at (740)591-9563 (cell) or by e-mail at cbagba@mix.wvu.edu

Thank you for your time and help with this project.

Sincerely,

Christopher Agba 


\section{Appendix B}

\section{Focus group discussion protocols}

This part of the process is focused on the youth. They are carefully recruited from the youth center and church associations within the neighborhood. These are those who are eighteen years and above, that were born in the neighborhood and spend three quarter of their lives within the area, excluding the times spent on vacation in other places. Their thoughts and experiences within and outside of the community will provide useful comparative information to the study. Most of the questions are focused on the future direction of the community. The locations are carefully chosen and made comfortable for participants. These are Dunbar School Annex, The Youth Center and a Church in the neighborhood. The participation time is approximately 1.5-2 hours. Snacks and refreshment will be provided. Confidentiality is assured as legally possible. There will first be an introduction and overview of the topic, the ground rules set, and the first question posed by the moderator (Krueger, 2002). Also, the researcher will be the moderator of the discussion and will be assisted by a couple of research colleagues who will help both to set up the location, organize participants, record the conversations. The research team will clean up after the meeting.

- What is it like to live in the Westside neighborhood?

- What do you think your parents want for your education?

- Which school did you graduate?

- Who has parents or grandparents with a connection to Dunbar?

- What do you think about segregation and racism in the neighborhood?

- What is your views on the relationship between the Westside and the Fairmont City?

- What higher educational technical training have you attained?

- What do you like to spend your time doing?

- What are some of the educational opportunities for the youth in the neighborhood?

- What are some of the social opportunities available for the youth?

- What community activities do you engage in?

- What is it that you want? Is that something you believe you can work toward and attain?

- What are your values?

- What are your struggles?

- What are you willing to work for?

- What are some of the crimes in the neighborhood?

- What help are you getting to combat these crimes?

- What community project will you like to see and be a part of?

- What do you think is responsible for these crimes and why? 
Focus group cover letter:

September 28, 2017

Dear Focus Group Participants,

This letter is a request for you to take part in a research project to gather information about the development of marginalized and segregated neighborhoods in West Virginia. The study is looking at historic events that happened at the Westside neighborhood of Fairmont that contributed to the collapse of the community. This project is being conducted by Christopher Agba, a Ph. D., candidate in the Department of Design and Community Development at West Virginia University. Your participation in this project is greatly appreciated and will take approximately 1.5-2 hours to complete. There is an audio-taped in-person group interview.

Your involvement in this project will be kept as confidential as legally possible. You must be 18 years of age or older to participate. Your participation is completely voluntary. You may skip any question that you do not wish to answer, and you may discontinue at any time. Although confidentiality is not guaranteed in this research format, I would ask that all participants keep the information discussed during the focus group confidential. West Virginia University's Institutional Review Board approval of this project is on file.

I hope that you will participate in this research project, as it could be beneficial in understanding and development of ideas that could help develop community driven projects. Thank you very much for your time. Should you have any questions about this letter or the research project, please feel free to contact Christopher Agba at (740) 591-9563 (cell) or by email at cbagba@mix.wvu.edu.

Thank you for your time and help with this project.

Sincerely,

Christopher Agba 